\title{
Harvest utilization rates and strategies for enhanced value recovery during primary processing in the central appalachian region
}

\author{
Shawn T. Grushecky \\ West Virginia University
}

Follow this and additional works at: https://researchrepository.wvu.edu/etd

\section{Recommended Citation}

Grushecky, Shawn T., "Harvest utilization rates and strategies for enhanced value recovery during primary processing in the central appalachian region" (2011). Graduate Theses, Dissertations, and Problem Reports. 3400 .

https://researchrepository.wvu.edu/etd/3400

This Dissertation is protected by copyright and/or related rights. It has been brought to you by the The Research Repository @ WVU with permission from the rights-holder(s). You are free to use this Dissertation in any way that is permitted by the copyright and related rights legislation that applies to your use. For other uses you must obtain permission from the rights-holder(s) directly, unless additional rights are indicated by a Creative Commons license in the record and/ or on the work itself. This Dissertation has been accepted for inclusion in WVU Graduate Theses, Dissertations, and Problem Reports collection by an authorized administrator of The Research Repository @ WVU.

For more information, please contact researchrepository@mail.wvu.edu. 


\title{
HARVEST UTILIZATION RATES AND STRATEGIES FOR ENHANCED VALUE RECOVERY DURING PRIMARY PROCESSING IN THE CENTRAL APPALACHIAN REGION
}

\author{
Shawn T. Grushecky \\ Dissertation Submitted to the \\ Davis College of Agriculture, Natural Resources and Design \\ at West Virginia University \\ in partial fulfillment of the requirements \\ for the degree of
}

Doctor of Philosophy

In

Forest Resources Science

\author{
Joseph McNeel, Ph.D., Chair \\ John R. Brooks, Ph.D. \\ Curt C. Hassler, Ph.D. \\ Jingxin Wang, Ph.D. \\ Jan Wiedenbeck, Ph.D.
}

Division of Forestry and Natural Resources

Morgantown, West Virginia

2011

Keywords: Hardwood, Utilization, Log grades, Pulpwood, Red oak Copyright 2011 Shawn T. Grushecky 


\begin{abstract}
UNDERSTANDING HARVEST UTILIZATION RATES AND STRATEGIES FOR ENHANCED

VALUE RECOVERY DURING PRIMARY PROCESSING IN THE CENTRAL APPALACHIAN REGION
\end{abstract}

Shawn T Grushecky

West Virginia has an abundant forest resource base that has underpinned portions of its economy for decades. These forests support a diverse primary and secondary forest products industry. A common thread that ensures the continued success of the forest industry, from the private landowners to the manufactures of fine furniture, is the strength of the logging and primary processing components of this supply chain. The purpose of this research is to evaluate the use of raw materials on logging operations, to understand the financial and operational aspects related to pulpwood merchandising, and to investigate new strategies for the development of standard hardwood log grades.

Whole-tree and landing-based utilization rates were determined from data collected on 30 active logging jobs in West Virginia during 2008. Utilization is defined as the amount of volume that is delivered to market over the total volume harvested for individual tree stems. On average, 3.6 markets were used by the loggers sampled. The average whole-tree utilization rate in the woods was $88 \%$ and was over $97 \%$ on the landings sampled. No relationship between the number of markets and utilization rate was determined. Results from this study provide estimates on the efficiency of forest resource use as well as the characteristics and quantity of material being left after harvest.

Roundwood merchandising operations have been seen as a potential way to supply raw materials to bioenergy facilities at competitive costs. The feasibility of developing such a facility in the central Appalachians was investigated. The purchase and subsequent merchandising of over 188 tons of hardwood pulpwood resulted in negative net revenues for all species studied. Handling cost was one of the largest contributing factors. As markets and pricing change, the metrics developed in this analysis can be used to produce new estimates of merchandising profitability.

Hardwood sawlog yield information is an important component that helps define hardwood sawmill profitability. This research investigated the use of cluster analyses and ordinal logistic regression in segregating red oak sawlogs based on potential revenue. A combination of statistical classification and an applied approach was found to be the best method for developing log grades. The final log grading table presented is not without problem; however it is the first comprehensive investigation of log grades in over 45 years and will help to begin the dialogue towards the development of a standardized hardwood log grading system. 


\section{ACKNOWLEDGEMENTS}

I would like to express my deep gratitude to the following people for their contributions toward this research project: to the numerous field crew members and colleagues that assisted in data collection over the last 5 years; to the funding agencies, the USDA Forest Service, the USDA CSREES Wood Utilization Program, and the State of West Virginia through the Appalachian Hardwood Center; to my committee members; Dr. John Brooks, Dr. Jingxin Wang, and Dr. Jan Wiedenbeck for helping me through this process; to Dr. Joe McNeel for his unrelenting encouragement and Dr. Curt Hassler for his help in maintaining focus; to the numerous landowners, loggers, and sawmill operators who collaborated on this effort; and finally, to my family who definitely bore the brunt of this work. It is my hope that the conclusions generated from this research will be of use to the forest products community and those they support. 


\section{TABLE OF CONTENTS}

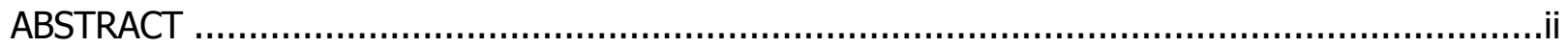

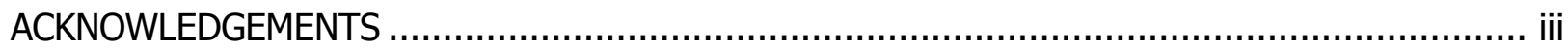

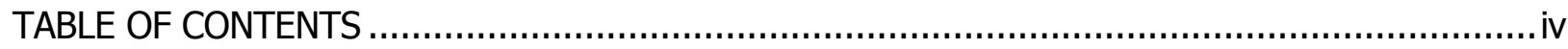

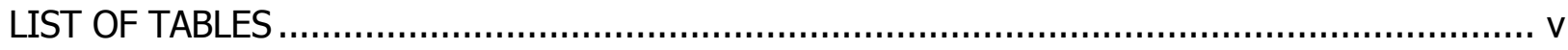

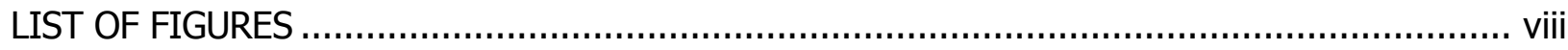

CHAPTER 1: ROUNDWOOD MARKETS AND UTILIZATION IN WEST VIRGINIA.......................... 1

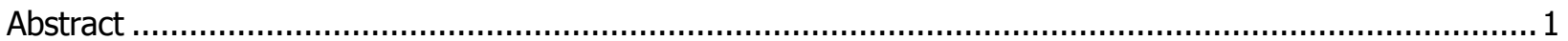

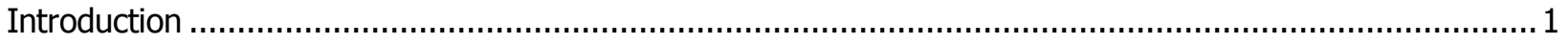

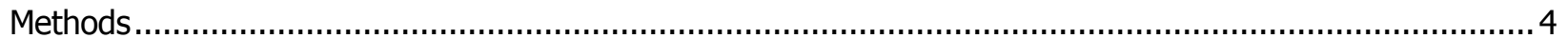

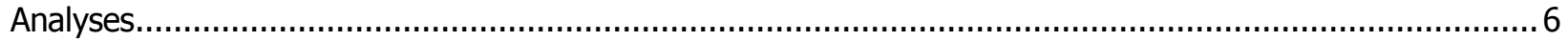

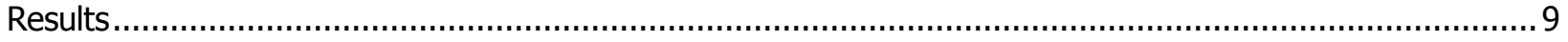

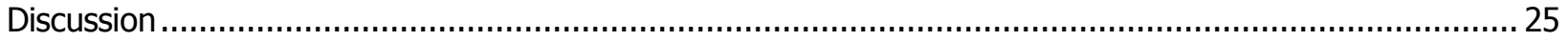

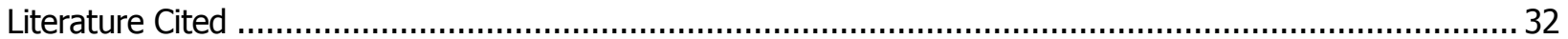

CHAPTER 2: ECONOMICS OF CO-MERCHANDISING PULPWOOD TO TRADITIONAL AND

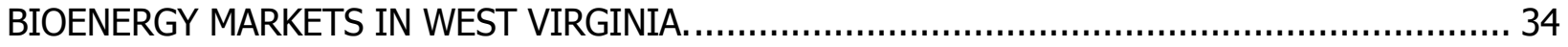

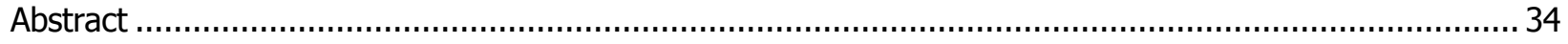

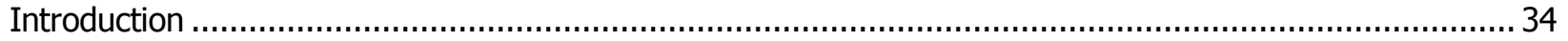

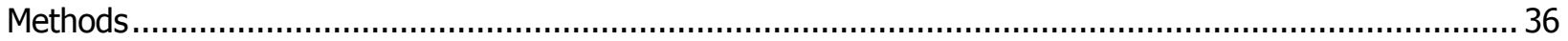

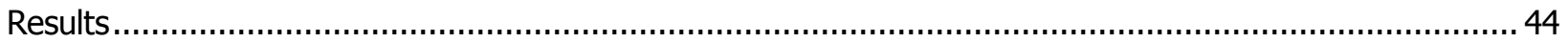

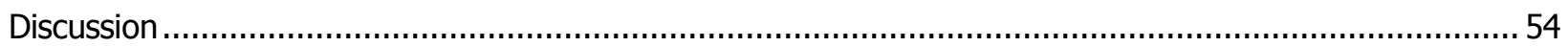

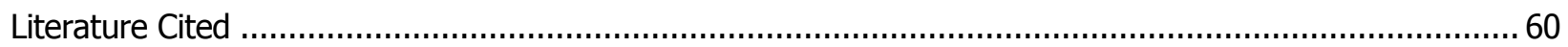

CHAPTER 3: A NON-HIERARCHICAL CLUSTERING AND ORDINAL LOGISTIC REGRESSION APPROACH TO DEVELOPING RED OAK LOG GRADES IN THE CENTRAL APPALACHIANS. ..........63

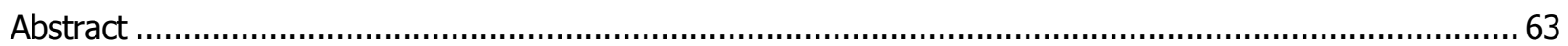

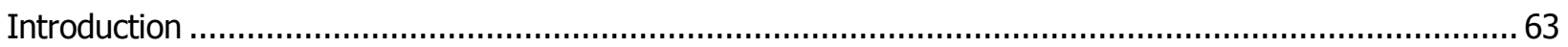

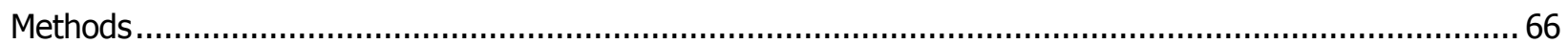

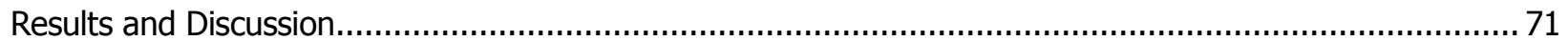

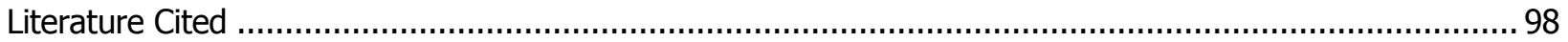




\section{LIST OF TABLES}

CHAPTER 1: ROUNDWOOD MARKETS AND UTILIZATION IN WEST VIRGINIA .......................... 1

Table 1.1. Pre-sampling data collected from WVDOF Harvest Notification forms for each region sampled during a 2008 roundwood utilization study in WV.

Table 1.2. Characteristics of loggers and logging sites sampled during a 2008 roundwood utilization study

in WV.

Table 1.3. Markets being used by loggers at thirty timber-harvests sampled during a 2008 roundwood utilization study in WV. Markets are sorted by descending frequency. .....

Table 1.4. Number of sample trees of each species encountered on 30 active timber harvests in West Virginia during 2008.

Table 1.5. Number of sample trees in each of 10 species groups measured on 30 active timber harvests in

West Virginia during 2008. Table sorted by descending number of occurrences.

Table 1.6. Average diameter at breast height (DBH), stump height, and stump diameter of trees in each of 10 species groups measured on 30 active timber harvests in West Virginia during 2008. Table is ordered by descending $\mathrm{DBH}$.

Table 1.7. Average bole lengths to a 9 inch and 4 inch (standard deviation) merchantable top for each of ten species groups from data collected on 30 active timber harvests in West Virginia during 2008............17 Table 1.8. Average end of utilization for each of ten species groups from data collected on 30 active timber harvests in West Virginia during 2008. .. 18

Table 1.9. Total volume $\left(\mathrm{ft}^{3}\right)$ and percent in-woods utilization for trees harvested on thirty sites in West Virginia during 2008.

Table 1.10. Percent in-woods utilization for each of ten species groups from data collected on 30 active timber harvests in West Virginia during 2008. Table sorted in descending order of total tree utilization. ... 19 Table 1.11. Average landing utilization rate for species groups sampled on thirty timber harvests in West Virginia during 2008. Table sorted in descending order of utilization......

Table 1.12. Percentage of products merchandised from hardwood trees during a 2008 harvest utilization study in West Virginia. Includes a breakdown for those trees with and without a sawlog being produced. 21 Table 1.13. Percentage of total volume merchandised by product class during a 2008 harvest utilization study in West Virginia. 17

Table 1.14. Percentage of total volume merchandised by product class and species group during a 2008 harvest utilization study in West Virginia...

Table 1.15. Average overall utilization rate which combines both in-woods and landing utilization for species groups sampled on thirty timber harvests in West Virginia during 2008. Table sorted in descending

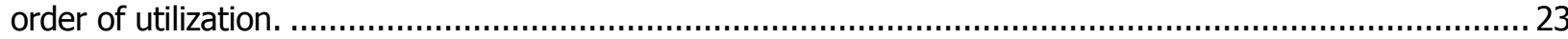
Table 1.16. Parameter average, standard deviation and range for variables included in model for predicting

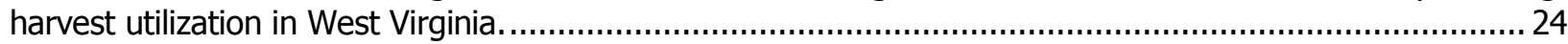
Table 1.17. Final model parameter estimates and associated standard errors for predicting total harvest utilization rate in West Virginia.

CHAPTER 2: ECONOMICS OF CO-MERCHANDISING PULPWOOD TO TRADITIONAL AND

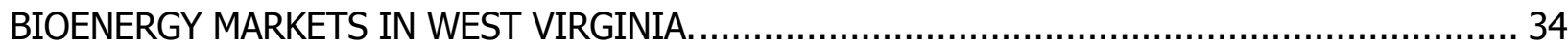

Table 2.1. Lumber (4/4) and cant prices ( $\$ /$ thousand board feet) delivered to receiving mill used in the

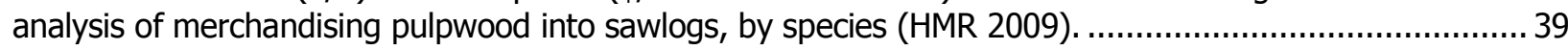

Table 2.2. Characteristics of pulpwood merchandised in West Virginia................................................. 45

Table 2.3. Characteristics of sawlogs merchandised from roundwood pulpwood, by species..................... 46

Table 2.4. Percentage lumber grade yields for sawlogs merchandized from pulpwood, by species............46 Table 2.5. Board footage sawn per ton of sawlogs, tonnages of sawlogs required to produce one thousand board feet of lumber and cants, and tonnages of pulpwood required to produce one thousand board feet of lumber and cants, by species. 
Table 2.6. Component costs for merchandising roundwood pulpwood into sawlogs and lumber and cant products, by species. All costs in terms of dollars per thousand board feet ( $\$ / M B F)$.

Table 2.7. Revenue per thousand board feet from sawmill residues, including bark, sawdust, and chips. Net revenue is based on the weight of sawlogs required to saw $1 \mathrm{MBF}$, the percent byproduct per ton and the price per ton for each sawing byproduct.

Table 2.8. Lumber and cant revenues per thousand board feet for sawlogs merchandised from pulpwood in West Virginia. Missing values indicate lumber grades not sawn from merchandised logs. ........................ 50

Table 2.9. Net revenues generated by merchandising pulpwood into sawlogs in West Virginia.................51

Table 2.10. Average value on a per ton basis for sawlogs merchandised from pulpwood......................... 51

Table 2.11. Proportional odds ratios for species effects and other predictor variables included in logistic regression model.

\section{CHAPTER 3: A NON-HIERARCHICAL CLUSTERING AND ORDINAL LOGISTIC REGRESSION APPROACH TO DEVELOPING RED OAK LOG GRADES IN THE CENTRAL APPALACHIANS.}

Table 3.1. Scaling diameter, length, and number of defect-free (clear) sides for red oak logs sawn in the Central Appalachian region. Clear sides reported as mean and (median) due to its categorical scale $(4,3,2,1,0)$

Table 3.2. Grade descriptions and pricing for red oak/black oak lumber. Grade descriptions include minimum board size and clear yield, lumber prices from 2004, 2008, and $2011 \ldots \ldots \ldots \ldots \ldots \ldots \ldots \ldots \ldots \ldots \ldots . . .73$

Table 3.3. Average lumber grade yields for red oak logs sawn at sawmills in the central Appalachian region.

Table 3.4. Log grade specifications synthesized during 45 sawmill visits in the Appalachian region. Scaling diameter is rounded to the nearest inch (e.g., $>15.5$ and $<=16.5$ represents the16 inch log class). .......... 75 Table 3.5. Total gross revenue per sawn board foot for standard lumber grades based on standard grading table grade designations (mean + standard deviation). Revenue based on the first week of June 2004, 2008, and 2011 lumber pricing.

Table 3.6. Average, standard deviation and coefficient of variation for select and better yields of red oak/black oak sawlogs classified by industry implied log grades.

Table 3.7. Average (standard deviation) select and better yields and gross revenue per board foot of lumber sawn (\$) for red oak log Type II log grades based on K-means clustering.

Table 3.8. Best model developed for predicting log inclusion into Type II log grades using ordinal logistic regression. All parameters were significant at $p<0.00001$.

Table 3.9. Odds ratio estimates for ordinal logistic regression model for predicting log inclusion into Type II log grades. All parameters were significant at $p<0.00001$.

Table 3.10. Type III log grading table developed using ordinal logistic model and predicted cell frequencies

Table 3.11. Average (standard deviation) select and better yields and gross revenue per board foot of lumber sawn for red oak log Type III log grades based on ordinal logistic model and frequency algorithm. 87 Table 3.12. Individual results from multiple attempts at multivariate K-means clustering for the development of red oak/black oak log grades. 88

Table 3.13. Average (standard deviation) number of clear sides and select and better yields for red oak/black oak log Type IV grades based on K-means clustering using number of clear sides and select and better yields.

Table 3.14. Best model developed for predicting log inclusion into Type IV log grades using ordinal logistic regression. All parameters were significant at $p<0.00001$.

Table 3.15. Odds ratio estimates for ordinal logistic regression model for predicting log inclusion into Type IV log grades. All parameters were significant at $p<0.00001$.

Table 3.16. Type $\mathrm{V}$ log grading table developed using ordinal logistic model and predicted cell frequencies

Table 3.17. Average (standard deviation) select and better yields and gross revenue per board foot of lumber sawn for red oak log Type IV log grades based on ordinal logistic model and frequency algorithm. 92 
Table 3.18. Comparison of five different approaches for developing red oak log grading table. Includes key parameters including the coefficient of variation (CV) for gross revenue per board foot sawn (\$) based on June 2011 lumber prices and the CV for select and better lumber yields..............................................9. 93 Table 3.19. Type III grading table with two cells modified (shaded). Original Type III table developed using ordinal logistic model and predicted cell frequencies algorithm. Cells that were modified are shaded........ 94 Table 3.20. Standard grading matrix with select and better yields and number of logs in parenthesis for red oak logs sawn in the central Appalachian region. ........................................................................ 95 Table 3.21. Hybrid Type III grading table for red oak sawlogs based on Type III table and select and better yield similarities.

Table 3.22. Average (standard deviation) select and better yields and gross revenue per board foot of lumber sawn for red oak log Type III hybrid log grades based on Type III table and select and better yield

similarities. 97 


\section{LIST OF FIGURES}

CHAPTER 1: ROUNDWOOD MARKETS AND UTILIZATION IN WEST VIRGINIA ........................ 1

Figure 1.1. Average ( \pm standard deviation) distance between log landing and markets for thirty harvests

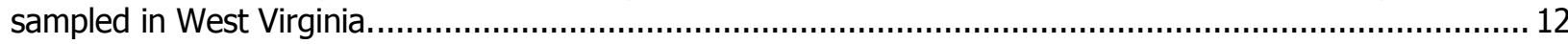

CHAPTER 2: ECONOMICS OF CO-MERCHANDISING PULPWOOD TO TRADITIONAL AND

BIOENERGY MARKETS IN WEST VIRGINIA.

Figure 2.1. Results from iterative analyses where sawlogs with given values/ton (X axis) were removed from the analyses and recoded as pulpwood based on their gross value per ton. Analyses were rerun and the impact on net revenues ( $Y$ axis) were evaluated. Sawlogs were separated based on values per ton less than $\$ 0-\$ 50 /$ ton in $\$ 5 /$ ton increments. APPROACH TO DEVELOPING RED OAK LOG GRADES IN THE CENTRAL APPALACHIANS.

Figure 3.1. Relationship between revenue per board foot sawn (\$) based on June 2011 lumber prices and select and better lumber yields for 1,472 red oak logs sawn in the central Appalachian region. ................. 77 Figure 3.2. Relationship between revenue per board foot sawn (\$) based on June 2011 lumber prices and select and better lumber yields for 1,472 red oak logs sawn in the central Appalachian region. Density ellipses are drawn on $50 \%$ of logs meeting Prime and Select implied grade yields. Prime represented by solid ellipse.

Figure 3.3. Plot of Select and better yield for Red Oak logs by gross revenue per board sawn (\$) using June 2011 lumber prices. Points represent individual red oak logs, point shapes represent K-means clusters for select and better yields.

Figure 3.4. Three dimensional scatterplot detailing results of K-means clustering of red oak logs. Results show Type IV log grade clusters using select and better yields (\%), number of clear sides and scaling diameter (inches) as response variables. Points represent logs, markers represent clusters. 


\section{Chapter 1: Roundwood Markets and Utilization in West Virginia}

\section{ABSTRACT}

Forest harvesting is an integral part of the West Virginia forest economy. This component of the supply chain supports a diverse array of primary and secondary processors. A key metric used to describe the efficiency of the roundwood extraction process is the logging utilization factor (LUF). The LUF is one way managers can discern the overall use of harvested roundwood. Roundwood utilization during harvesting operations was investigated on 30 active sites during 2008. Approximately 3.6 markets were used by the loggers sampled. The average whole-tree utilization rate in the woods was $87.8 \%$ for trees sampled during this study. Over $97 \%$ of the roundwood that was on the landing was utilized. No relationship was found between the number of markets and utilization rates. Results from this study provide estimates on the overall efficiency of harvest operations as well as the characteristics and quantity of material being left after harvest. This information is important to those involved in the management of the hardwood resource as well as those making investments in wood processing industries.

\section{INTRODUCTION}

During the last two decades, major changes have impacted the Appalachian forest product sector. Probably the most notable has been the dramatic decline in domestic furniture production. US manufactures have not been able to compete with furniture imports, most of which has been spurred by increased globalization, as well as lower labor and environmental costs in other parts of the world (Schuler et al. 2001). Traditional roundwood using manufacturers have also seen shifts in wood fiber value streams including increases in 
consumption by engineered product producers as well as increased attention by energy producers (Grushecky et al. 2007).

Thus both global competition and shifts in domestic markets have increased the importance of proper utilization of our forest resource. Production efficiency must be documented and enhanced through the entire forest to markets supply chain. Understanding manufacturing efficiencies from harvesting through the primary production stage will help increase the productive capacity of our forest products sector. This will ultimately also benefit the standing hardwood resource.

The USDA Forest Service has been the primary source for information regarding the utilization of hardwoods in the Appalachian region. The Timber Products Output group (TPO) within the Forest Service tracks resource removals and their impacts on the forest and economies of the United States. This includes three components; 1) surveys of both industrial and nonindustrial primary (roundwood) timber products users, 2) determination of logging utilization rates, and 3) combining logging utilization information with TPO information to obtain removals. Two utilization factors are calculated during this process, a logging utilization factor (LUF) and a sawmill utilization factor (SUF). The LUF represents the ratio of harvested roundwood volume that is left in the woods versus that brought to market. The sawmill utilization factor helps us understand the conversion efficiency during primary processing. It is constructed by comparing the amount of residues (bark, chips, and dust) produced versus the amount of product produced. Of these components, logging utilization research gives us the most information regarding the waste associated with the harvest of hardwood timber. The LUF can be used to determine removals by applying it to the volume of wood reportedly processed by facilities in any given state (Blyth and Smith, 1979). 
Other methods, such as line intersect sampling, have been used to estimate the volume of logging residues remaining after harvest in West Virginia (Grushecky et al. 1997; Grushecky et al. 2006). Although no relationships were found, the impact of available markets at the time of harvest on logging residue levels have been investigated (Grushecky et al. 2007). While these studies help to develop a better understanding of waste wood availability, they do not identify the reason for the wood being available in the first place. Because these surveys are done after harvest, there is no information available on the influence of site conditions and markets on overall utilization. Combining both the assessment of the harvested resource and the available markets at the time of harvest can increase our understanding of roundwood utilization.

Because of their combined scope, logging utilization studies, such as those performed by the USDA Forest Service (Bentley and Johnson 2006, 2009), provide better utilization information. However, the intensity of these studies comes at a cost. In the northeastern United States, which includes West Virginia, a single set of LUFs have been in use, despite wide variation in forests, species, and markets. Another issue with the current LUFs being used in the northeastern United States is the fact that they are at least two decades old. Because of the changes in technology and available markets, LUFs should be updated on a more consistent basis. Even with these challenges, LUFs are an important tool for determining the availability of wood fiber in a region. They are used by many to assess regional timber supply and demand scenarios for locating new wood products facilities. Likewise, increased importance has been placed on TPO information because of a renewed emphasis on biofuel production. Because of their availability and perceived low cost, wood byproducts are often the first raw material sourced when developers are interested in locating a new bioenergy facility.

The objectives of this research project are to investigate roundwood utilization rates on timber harvests in West Virginia. This includes determining the impact of harvest location and 
characteristics on overall utilization rates, as well as developing a model to predict utilization based on a limited sampling approach.

\section{METHODS}

To investigate roundwood utilization in West Virginia, thirty active timber harvests were sampled during the summer/early fall of 2008. The population of harvest sites was obtained from West Virginia Division of Forestry logging notification forms. In West Virginia, the notification of timber harvesting is mandated under the 1992 Logging Sediment Control Act (Grushecky et al., 2006). To reduce variability due to species composition, harvest type, and terrain, harvests were stratified based on the three USDA Forest Service Forest Inventory and Analysis (FIA) units (Alderman and Luppold, 2005) in West Virginia. Approximately 20 harvests from each of the FIA units were randomly selected from the overall harvest population. A greater number of delineated sites were needed due to harvest completions, permission problems, and size constraints which limited the feasibility of completing sampling on some of the harvest sites.

The sampling methodologies used at each site were patterned after the techniques used by the USDA Forest Service Southern Research Station (Bentley and Johnson 2009). The goal for each site was to sample thirty felled trees for utilization. Utilization information was collected when the tree was felled and subsequently merchandised in the woods as well as when the tree was bucked and prepared for market at the landing. Landing utilization data collection was not collected by Bentley and Johnson $(2006,2009)$, allowing our study a unique perspective.

\section{In-woods utilization}

Once an active harvest site was chosen, the field crews met with the logging supervisor before field work commenced. A survey instrument was used to collect general harvest information including: 
1. GPS coordinate of landing

2. Type and specification of all product markets

3. Number of active loggers on each site

4. Number of truckloads leaving site each day

5. Location of all product markets

6. Forester involvement

7. Type of logger (contractor, independent, company)

8. Harvest type

9. Equipment specifications

The field crew then noted the current location of harvesting within the tract and the general direction of harvest progression. With this information, the field crew members could be positioned a safe distance from harvesting while the logging crew could fell several trees in a given area. Once the trees were felled, the field crew collected the following information for each tree:

1. Species

2. Stump height

3. Stump Diameter

4. Diameter at $12^{\prime \prime}$ stump

5. $\mathrm{DBH}$

6. Diameter at $16^{\prime} \log$

7. Diameter and distance to topping point in woods

8. Diameter and distance to 9 " top of main stem

9. Diameter and distance to 4 " top of main stem 
10. Large and small end diameters for each portion of the felled tree remaining as long as they met a 4 " diameter and 8 ' length minimum

11. Utilization (binary) of each measured piece

\section{Landing Utilization}

The felled trees were sequentially numerated by painting on the large and small end of the logs. At some point, the logs were then skidded to the landing by the logging crews. Once the tree stem portions arrived at the log landing, another field crew member recorded the following information for each bucked stem:

1. Tree number (from the woods)

2. Large and small end diameter

3. Total log length

4. Product category for each log

5. Large and small end diameter for any unutilized piece

\section{ANALYSES}

Upon return from field visits, all data were entered electronically. Since this project produced a tremendous amount of data, significant attention was given to data checking and resolving discrepancies before analyses could proceed. All markets were geo-spatially identified and the distance from each landing to each product market was determined using a web-based travel network algorithm.

An overall utilization rate was calculated based on cubic-foot volume for each measured tree. This included whole-tree utilization (including branches) and main-bole utilization. Utilization rates were calculated based on a 4 " small end diameter of merchantability cutoff. Landing utilization was calculated for each numerated tree that was skidded to the landing. Not 
all numerated trees were measured on the landing because they were not skidded from the field, were dropped by the skidder along the way, or had illegible tags/numbering due to environmental conditions.

The influence of market distance on utilization rates were investigated using Pearson correlation. The actual distances to current markets as well as calculated distances to all major pulpwood and OSB markets in WV and surrounding states (even if they were not being used) were developed for each site. The relationship between utilization rate and other site factors including forester involvement, type of logger (contract, independent, and company), number of product markets, mechanization, and number of employees was tested using analysis of variance (ANOVA). The following general model was used for all tests:

$$
Y_{i j}=\mu+\alpha_{i}+\varepsilon_{i j}
$$

Where $Y_{i j}$ is the utilization rate over all 30 sites, $\mu$ is the overall mean, $\alpha_{i}$ is the effect of the ith treatment and $\varepsilon_{i j}$ is the unexplained variability. Least-square means were used for multiple comparison testing. For both number of product markets and number of employees, data were recoded into two categories - "high" and "low". High represented measurements equal to or greater than the mean response for that particular indicator. Low represented all other measurements.

Another goal of this research was to determine whether an appropriate model could be developed to predict overall site utilization based on a limited number of measurements. Because utilization at the site level is the response of interest, prediction data were developed at the site level $(n=30)$ for modeling. Likewise, the ultimate goal of developing this model is to predict overall utilization rate mainly from variables that could be collected on the landing. This helps 
reduce the complexity of data collection and interference that might reduce the loggers productivity. It could also reduce the costs associated with field work and provide a safer work environment for data collectors. As part of model development, a large number of predictor variables were assessed for their predictive capability including:

1. the average of the smallest diameters measured from each tree tallied as well as the average of the squared smallest diameters,

2. the average scaling diameter of the first log from each tree,

3. the ratio of the average smallest diameter to the average scaling diameter from the first log for each tree measured on the landing,

4. the average maximum large diameter of each tree measured on the landing (butt diameter),

5. the distance to sawlog, pulpwood, and OSB markets,

6. the mechanization level of the loggers (fully mechanized versus not fully-mechanized),

7. type of logging contractors,

8. percentage of oak trees measured on landing,

9. the percentage of yellow-poplar trees measured on the landing,

10. the percentage of oak pieces measured on the landing,

11. the percentage of yellow-poplar pieces measured on the landing,

12. the total number of pieces measured on the landing,

13. and the average $\mathrm{DBH}$ as well as the $\mathrm{DBH}^{2}$ of harvested trees.

Outlier analyses were performed as well as tests for multicollinearity. No observations were removed from the analysis based on their dispersion. Predictive variables were reduced from the original 17 to 10 by examining collinearity as well as relationships to total utilization. Akaike's entropy-based Information Criterion (AIC) was then used to select the best overall model 
for predicting total utilization rate (Bozdogan 1987). AIC provides a better estimate of the "true" model because it alleviates the lack of model independence that occurs when using forward, backward, stepwise or other similar variable selection methods.

\section{RESULTS}

\section{Sites}

Pre-sampling harvest characteristics based on WVDOF notification data varied in each of the three WVDOF regions (Table 1.1). Region two, which encompasses the southern portion and central mountain counties had the highest level of active harvests during the sampling period.

Table 1.1. Pre-sampling data collected from WVDOF Harvest Notification forms for each region sampled during a 2008 roundwood utilization study in WV.

\begin{tabular}{lccc}
$\begin{array}{l}\text { WV Division of Forestry } \\
\text { Region }\end{array}$ & Total Acres Being Harvested & $\begin{array}{c}\text { Average Harvest Size } \\
\text { (acres) }\end{array}$ & Number of Harvests \\
\hline 1 & 10,541 & 56 & 188 \\
2 & 21,909 & 79 & 276 \\
3 & 17,435 & 99 & 175 \\
\hline
\end{tabular}

A total of 10 harvests from each of the three WVDOF regions were sampled during the summer/fall of 2008. Numerous sites were passed over because they were not active or the logging operator failed to give permission to collect data on the harvest.

\section{Logging Crew Characteristics}

The majority of the loggers sampled were contract or independent loggers. Company crews composed only $13 \%$ of the sample (Table 1.2). Twenty-percent of the loggers used a mechanical felling machine and twenty-seven percent used a grapple skidder. On the landing, $70 \%$ of the loggers sampled used a mechanical bucking loader/saw (sawbuck). Of the thirty harvests sampled, five (17\%) used a mechanical harvester, grapple skidder and sawbuck, and 
thus could be considered fully mechanized. The majority of the harvest operations that we sampled were on private land (93\%) and had a professional forester involved in the harvest (73\%). All of the fully mechanized harvests had professional forester involvement. On average, contract loggers had forester involvement on $78 \%$ of the harvests sampled, followed by $75 \%$ for company crews and $67 \%$ for independents.

Table 1.2. Characteristics of loggers and logging sites sampled during a 2008 roundwood utilization study in WV.

\begin{tabular}{lcc}
\hline Logger Characteristic & Number of Sites & Percent \\
\hline Contract Logger & 14 & $47 \%$ \\
Independent Logger & 12 & $40 \%$ \\
Company Crew & 4 & $13 \%$ \\
Mechanical Harvester & 6 & $20 \%$ \\
Sawbuck & 21 & $70 \%$ \\
Grapple Skidder & 8 & $27 \%$ \\
Private Land & 28 & $93 \%$ \\
Forester Involvement & 22 & $73 \%$ \\
\hline
\end{tabular}

The number of employees (excluding truckers) working on each site ranged from 2 to 9 . The average number of employees for each of the harvests was 4.4. Mechanized harvests averaged more employees than non-mechanized (6.0 versus 4.0). Contract loggers averaged 4.9 employees, independents averaged 3.6 and company crews averaged 4.8 employees on site. Four out of the five fully mechanized harvests were contract logging crews.

The reported number of product truckloads produced per day ranged from 1 to 9 . The average number of truckloads was 3.3. Fully-mechanized harvests produced 5.2 loads per day compared to an average of 3.0 for non-mechanized crews. Contract loggers produced the greatest number of loads per day (3.6) followed by company crews (3.2) and independents (3.0). 


\section{Markets}

Nine primary markets were identified during the sampling of the thirty harvest operations (Table 1.3). As expected, each one of the sites produced sawlogs (Table 1.3). Following sawlogs, the next most common market was oriented strandboard pulp (OSB) followed by pulpwood and yellow-poplar peeler logs (Table 1.3).

Table 1.3. Markets being used by loggers at thirty timber-harvests sampled during a 2008 roundwood utilization study in WV. Markets are sorted by descending frequency.

\begin{tabular}{lcc}
\hline Market & Number of sites delivering to market & Percent of total \\
\hline Sawlogs & 30 & $100 \%$ \\
Oriented Strandboard pulp & 18 & $60 \%$ \\
Yellow-poplar peelers & 17 & $57 \%$ \\
Pulpwood & 17 & $57 \%$ \\
Fence rails & 9 & $30 \%$ \\
Firewood & 6 & $20 \%$ \\
Scragg & 5 & $17 \%$ \\
Fence posts & 3 & $10 \%$ \\
High-quality sawlog (Veneer) & 3 & $10 \%$ \\
\hline
\end{tabular}

The number of markets used ranged from 1 to 6 and averaged 3.6 for each of the harvests visited. Markets used by contract, independent and company loggers did not differ greatly, each averaged 3.5, 3.7, and 3.5 markets, respectively. Harvests that had a forester averaged 3.8 product markets and those without averaged 3.0.

Forty-seven percent of the sites delivered to sawlog as well as major pulpwood and OSB pulp markets. Fifty-percent of sites with a forester delivered to both sawlog and OSB and pulp markets, whereas thirty-eight percent of sites without a forester used these markets. Half of both contract and company crews delivered to both sawlog and OSB and pulp markets, whereas $42 \%$ of independents did the same. 
When looking at all major sawlog, pulp markets and peeler markets, $33 \%$ of the loggers sampled delivered to sawlog markets as well as all these markets. Again, half of company loggers delivered a sawlog product and to all major peeler and pulp markets, followed by $36 \%$ of contract loggers and $25 \%$ of independents. Forester involvement also impacted delivery to major sawlog, peeler and pulp markets. Thirty-six percent of harvests with a forester delivered to these markets compared to twenty-five percent of those without.

Distances between individual markets ranged from 23.3 miles for those that delivered to scragg markets to 138.7 miles for high quality sawlog markets (Figure 1.1).

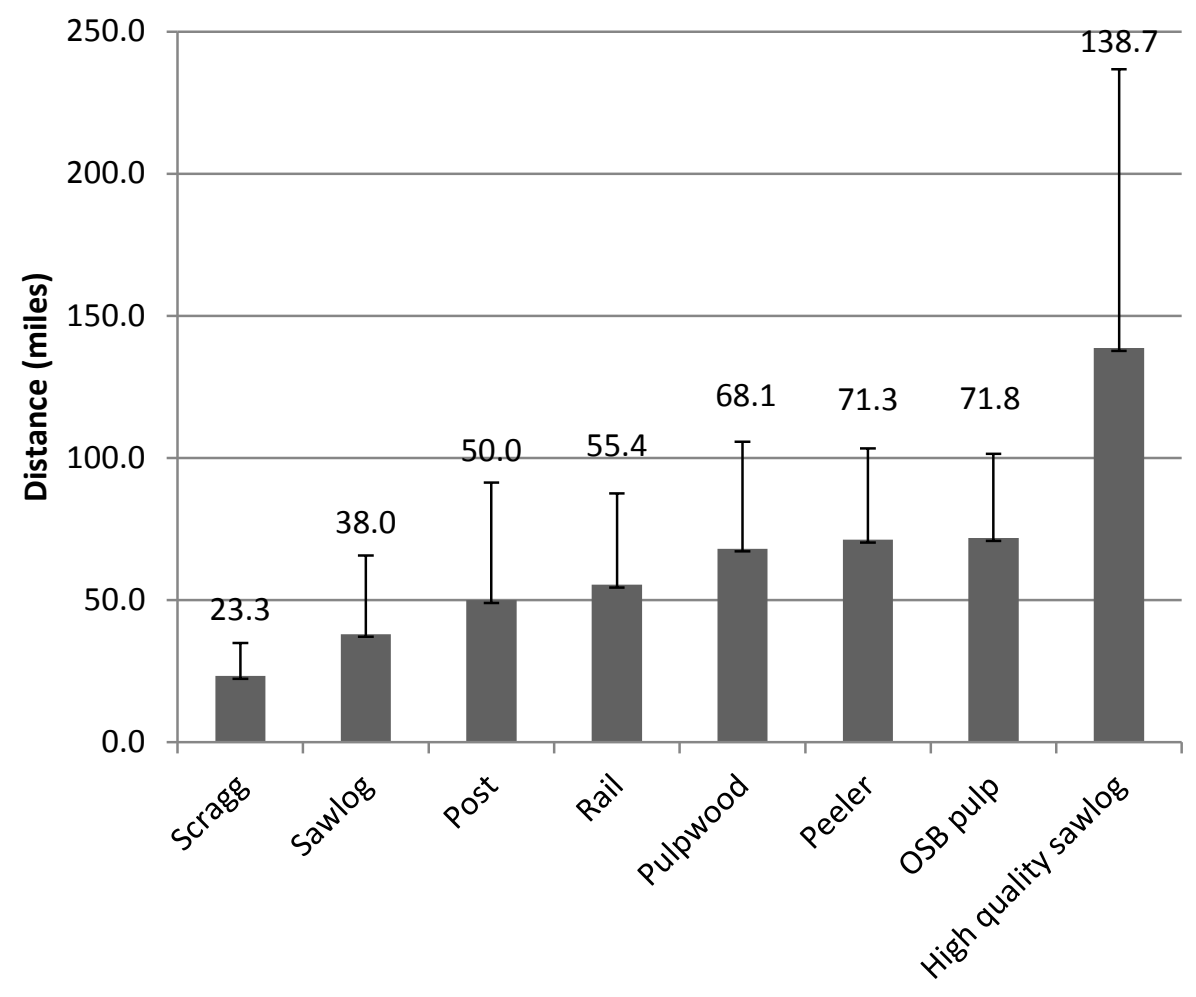

Product

Figure 1.1. Average ( \pm standard deviation) distance between log landing and markets for thirty harvests sampled in West Virginia. 
Sawlog markets averaged 38 miles ( \pm 27.7). Distances to pulpwood, peeler, and OSB pulp were relatively consistent, averaging $68.1,71.3$ and 71.8 miles respectively. The average distance to the closest pulpwood and OSB pulp facilities for those sites that did not include them as markets averaged 85.2 and 84.3 miles, respectively. The minimum distance to a wood products facility that was not delivered to was 34.4 miles for pulpwood and 44 miles for OSB pulp.

\section{In-woods utilization}

A total of 816 felled trees were sampled during this study, 84 less than the goal of 900 trees. Missing trees were mostly due to loggers finishing work before all trees were measured or the harvest being completed before sampling was finished. Twenty-three species were represented by the samples taken on the thirty harvests (Table 1.4). 
Table 1.4. Number of sample trees of each species encountered on 30 active timber harvests in West Virginia during 2008.

\begin{tabular}{lcc}
\hline Species & No. & Percent of total \\
\hline Yellow-poplar & 208 & 25.5 \\
Red Maple & 114 & 14.0 \\
Black/Red Oak & 78 & 9.6 \\
Chestnut Oak & 76 & 9.3 \\
White Oak & 73 & 8.9 \\
Sugar Maple & 52 & 6.4 \\
Eastern White Pine & 39 & 4.8 \\
Hickory Spp. & 39 & 4.8 \\
American Beech & 34 & 4.2 \\
Black Cherry & 28 & 3.4 \\
Eastern Hemlock & 17 & 2.1 \\
White Ash & 16 & 2.0 \\
Cucumber & 9 & 1.1 \\
Black Birch & 7 & 0.9 \\
Black Locust & 5 & 0.6 \\
American Basswood & 3 & 0.5 \\
Black Gum & 4 & 0.5 \\
Sassafras & 4 & 0.5 \\
Bigtooth Aspen & 4 & 0.4 \\
Paper Birch & 3 & 0.4 \\
Pine Spp. & 3 & 0.2 \\
Black Walnut & 0.1 \\
\hline
\end{tabular}

Yellow-poplar had the highest frequency of samples, followed by red maple and black/red oak. When species were grouped by specific physical and market characteristics, the yellowpoplar group was the most prevalent (Table 1.5). This was followed by the white oak, soft maple, and red oak groups. 
Table 1.5. Number of sample trees in each of 10 species groups measured on 30 active timber harvests in West Virginia during 2008. Table sorted by descending number of occurrences.

\begin{tabular}{lcc}
\hline Species Group $^{1}$ & No. & Percent of total \\
\hline Yellow-poplar & 208 & 25.5 \\
White oak & 149 & 18.3 \\
Soft maple & 114 & 14.0 \\
Red oak & 78 & 9.6 \\
Mixed-hardwood & 74 & 9.1 \\
Pine spp. & 58 & 7.1 \\
Hard maple & 52 & 6.4 \\
Hickory spp. & 39 & 4.8 \\
Cherry & 28 & 3.4 \\
Soft-hardwood & 16 & 2.0
\end{tabular}

\footnotetext{
${ }^{1}$ Yellow-poplar includes only yellow-poplar (Liriodendron tulipifera); white oak includes white (Quercus alba) and chestnut oak (Quercus prinus); soft maple includes only red maple (Acer rubrum); red oak includes red (Quercus rubra) and black (Quercus velutina) oaks, mixed-hardwoods includes American beech (Fagus grandifolia), white ash (Fraxinus americana), black birch (Betula lenta), black locust (Robinia pseudoacacia), black gum (Nyssa sylvatica), sassafras (Sassafras albidum), paper birch (Betula papyrifera), and black walnut (Juglans nigra); pine spp. includes members of pinus genera, hard maple includes only sugar maple (Acer saccharum), hickory spp. includes all hickories (Carya spp.), cherry includes only black cherry (Prunus serotina), and soft-hardwood includes cucumber (Magnolia acuminata), American basswood (Tilia americana), and bigtooth aspen (Populous grandidentata).
}

The average diameter at breast height (DBH) for the 816 trees measured was 16.9 inches ( \pm 4.5 inches), the average stump height was 9.8 inches ( \pm 7 inches), and the average stump diameter was 20.6 inches ( \pm 5.6 inches). The soft maple species group had the smallest DBH and stump diameter. The red oak species group had the largest DBH and stump diameter, followed by the hard maple and black cherry species groups (Table 1.6). Hickory spp. and pine spp. had the lowest average stump heights. Although both still below a 12-inch stump, white oak and hard maple had the highest average stump heights. 
Table 1.6. Average diameter at breast height (DBH), stump height, and stump diameter of trees in each of 10 species groups measured on 30 active timber harvests in West Virginia during 2008. Table is ordered by descending DBH.

\begin{tabular}{lccc}
\hline Species Group & DBH (in) & Stump Height (in) & Stump Diameter (in) \\
\hline Red Oak & $18.9( \pm 4.1)$ & $9.8( \pm 7.3)$ & $24.7( \pm 5.8)$ \\
Hard Maple & $18.3( \pm 4.5)$ & $10.7( \pm 5.0)$ & $21.8( \pm 6.3)$ \\
Cherry & $18.1( \pm 2.9)$ & $9.7( \pm 2.2)$ & $20.9( \pm 4.7)$ \\
White Oak & $17.7( \pm 5.0)$ & $11.0( \pm 10.1)$ & $22.0( \pm 4.8)$ \\
Yellow-poplar & $17.5( \pm 4.2)$ & $10.0( \pm 7.6)$ & $20.8( \pm 5.5)$ \\
Soft Hardwood & $16.7( \pm 3.3)$ & $10.6( \pm 5.1)$ & $19.5( \pm 4.8)$ \\
Hickory Spp. & $15.6( \pm 3.0)$ & $7.3( \pm 5.7)$ & $20.8( \pm 4.1)$ \\
Mixed Hardwood & $15.4( \pm 3.5)$ & $10.4( \pm 5.5)$ & $18.4( \pm 4.1)$ \\
Pine Spp. & $15.1( \pm 5.5)$ & $7.3( \pm 4.5)$ & $18.8( \pm 7.0)$ \\
Soft Maple & $14.8( \pm 4.1)$ & $9.1( \pm 3.3)$ & $17.4( \pm 4.9)$ \\
\hline
\end{tabular}

The average tree bole length to a 9-inch merchantable top was 49.8 feet ( \pm 24.2 feet). Not all stems had a merchantable height that was exactly 9-inches due to branching and other stem form inconsistencies. The average diameter at the 9-inch merchantability point was 9.3 inches ( \pm 0.8 inches) for all stems measured. The average bole length to at least a 4-inch merchantable top was 69.4 feet ( \pm 4.5 feet). Again, not all stems had a merchantable height that was exactly 4 -inches. The average diameter at the 4-inch merchantability point was 4.3 inches ( \pm 0.6 inches). Yellow-poplar stems had the largest bole length to a 9-inch and 4-inch top at 60.3 feet and 80.3 feet respectively. The mixed-hardwood species group had the shortest length to a 9-inch and 4-inch top (Table 1.7). 
Table 1.7. Average bole lengths to a 9 inch and 4 inch (standard deviation) merchantable top for each of ten species groups from data collected on 30 active timber harvests in West Virginia during 2008.

\begin{tabular}{lcc}
\hline Species Group & $\begin{array}{c}\text { Bole Length } \\
\text { To 9" top (ft) }\end{array}$ & $\begin{array}{c}\text { Bole Length } \\
\text { To 4" top (ft) }\end{array}$ \\
\hline Cherry & $49.7( \pm 11.2)$ & $65.9( \pm 11.4)$ \\
Hickory Spp. & $46.2( \pm 13.6)$ & $69.1( \pm 10.6)$ \\
Hard Maple & $48.8( \pm 15.3)$ & $68.2( \pm 13.6)$ \\
Mixed Hardwood & $37.6( \pm 15.9)$ & $57.3( \pm 15.1)$ \\
Pine Spp. & $41.4( \pm 27.3)$ & $64.6( \pm 21.1)$ \\
Red Oak & $53.7( \pm 15.5)$ & $74.4( \pm 13.8)$ \\
Soft Hardwood & $50.9( \pm 16.2)$ & $69.4( \pm 13.8)$ \\
Soft Maple & $38.7( \pm 15.4)$ & $58.6( \pm 13.9)$ \\
White Oak & $51.8( \pm 39.8)$ & $68.7( \pm 12.3)$ \\
Yellow-poplar & $60.3( \pm 16.0)$ & $80.3( \pm 15.1)$ \\
\hline
\end{tabular}

The average in-woods bucking point or end of utilization along the main stem for all trees sampled was 9.4 inches ( \pm 3.9 inches). This represents the diameter at which the loggers bucked the main stem in the woods. The red oak species group had the largest diameter at the end of utilization at 11.5 inches, followed by hard maple at 11.3 inches. The pine group and soft maple had the smallest diameter at the end of utilization point of 5.9 and 8.3 inches, respectively (Table 1.8). 
Table 1.8. Average end of utilization for each of ten species groups from data collected on 30 active timber harvests in West Virginia during 2008.

\begin{tabular}{lc}
\hline Species Group & End of Utilization (in) \\
\hline Cherry & $9.4( \pm 3.2)$ \\
Hickory Spp. & $9.4( \pm 3.3)$ \\
Hard Maple & $11.3( \pm 4.6)$ \\
Mixed Hardwood & $8.7( \pm 3.3)$ \\
Pine Spp. & $5.9( \pm 3.3)$ \\
Red Oak & $11.5( \pm 3.9)$ \\
Soft Hardwood & $10.7( \pm 2.6)$ \\
Soft Maple & $8.3( \pm 3.4)$ \\
White Oak & $10.2( \pm 4.3)$ \\
Yellow-poplar & $9.4( \pm 3.6)$ \\
\hline
\end{tabular}

A total of $74,972 \mathrm{ft}^{3}$ of harvested trees were sampled during the thirty visits. Total tree utilization ranged from $75.4 \%$ to $99.1 \%$. Average whole-tree utilization was $87.8 \%$. Sawlog sized material measured totaled $65,823 \mathrm{ft}^{3}$ and had an average utilization rate of $94.1 \%$. Sawlog utilization ranged from $82.1 \%$ to $99.9 \%$. Over nine thousand cubic feet of pulp-sized material was measured, $42.5 \%$ of was utilized (Table 1.9 ). Pulp utilization ranged from $0 \%$ to $95 \%$ on the thirty sites.

Table 1.9. Total volume $\left(\mathrm{ft}^{3}\right)$ and percent in-woods utilization for trees harvested on thirty sites in West Virginia during 2008.

\begin{tabular}{ccccccccc}
\hline \multicolumn{2}{c}{ Total Sawlog Vol. $\left(\mathrm{ft}^{3}\right)$} & \multicolumn{2}{c}{ Total Pulpwood Vol. $\left(\mathrm{ft}^{3}\right)$} & \multicolumn{2}{c}{ Total Tree Volume $\left(\mathrm{ft}^{3}\right)$} & \multicolumn{3}{c}{ Utilization (\%) } \\
Used & Not-used & Used & Not-Used & Used & Not-used & Sawlog & Pulp & Total Tree \\
\hline $61,932.6$ & $3,890.5$ & $3,887.2$ & $5,261.6$ & $65,819.9$ & $9,125.1$ & 94.1 & 42.5 & 87.8 \\
\hline
\end{tabular}

The pine species group had the highest overall utilization rate $(96.3 \%)$, followed by the yellow-poplar and black cherry groups (Table 1.9). The soft-hardwood group had the lowest utilization rate $(79.0 \%)$, followed by the hard maple and mixed hardwood groups. Sawlog 
utilization among species groups followed similar patterns as total tree utilization, the pine species group (98.7\%) had the highest use percentage and the soft-hardwood group had the lowest (88.1\%) (Table 1.10).

Table 1.10. Percent in-woods utilization for each of ten species groups from data collected on 30 active timber harvests in West Virginia during 2008. Table sorted in descending order of total tree utilization.

\begin{tabular}{lccc}
\hline Species Group & \multicolumn{3}{c}{ Utilization (\%) } \\
\hline Pine Spp. & Sawlog & Pulp & Total Tree \\
Yellow-poplar & 98.7 & 82.9 & 96.4 \\
Cherry & 95.9 & 46.3 & 91.0 \\
Soft Maple & 96.3 & 46.7 & 90.3 \\
Hickory Spp. & 94.9 & 54.7 & 87.7 \\
Red Oak & 94.9 & 39.9 & 87.0 \\
White Oak & 92.0 & 20.8 & 85.6 \\
Mixed Hardwood & 92.7 & 32.7 & 84.7 \\
Hard Maple & 91.9 & 43.1 & 84.1 \\
Soft Hardwood & 91.0 & 26.3 & 83.8 \\
\hline
\end{tabular}

\section{Landing Utilization}

A total of 796 trees were measured on the landing during this study. This is less than the 816 trees measured in the woods because several trees were lost between the woods and the landing. These trees do not represent unutilized stems, rather they were not skidded to the landing during the study period or the numbers written on the logs became illegible during transport.

The average utilization rate found on the landings sampled was $97.9 \%( \pm 5.6 \%)$. Variation among species groups was not pronounced ranging from $96.3 \%$ for soft-hardwoods to $99.4 \%$ for hard maple species groups (Table 1.11). 
Table 1.11. Average landing utilization rate for species groups sampled on thirty timber harvests in West Virginia during 2008. Table sorted in descending order of utilization.

\begin{tabular}{lc}
\hline Species Group & Utilization (\%) \\
\hline Hard Maple & 99.4 \\
Mixed Hardwood & 98.8 \\
Pine Spp. & 98.0 \\
Soft Maple & 98.0 \\
Red Oak & 97.8 \\
Cherry & 97.7 \\
Hickory Spp. & 97.7 \\
Yellow-poplar & 97.6 \\
White Oak & 97.4 \\
Soft Hardwood & 96.3 \\
\hline
\end{tabular}

Approximately $66.8 \%$ of all trees had a sawlog merchandised from them on the landing. Pulpwood was merchandised from $56.3 \%$ of the stems (Table 1.11). Of those trees where a sawlog was merchandised, only $8.7 \%$ also had a peeler, and $50.6 \%$ also contained pulp material. Furthermore, of those stems where a sawlog was not merchandised, peelers made up $22.4 \%$ and pulpwood $67.8 \%$ of the products, respectively (Table 1.12). Several of these percentages may be confounded with species of tree being utilized, some markets (such as yellow-poplar peelers) only correspond to one species. 
Table 1.12. Percentage of products merchandised from hardwood trees during a 2008 harvest utilization study in West Virginia. Includes a breakdown for those trees with and without a sawlog being produced.

\begin{tabular}{|c|c|c|c|}
\hline \multirow[b]{2}{*}{ Product } & \multicolumn{3}{|c|}{ Percent of Occurrence (\%) } \\
\hline & All Trees & $\begin{array}{c}\text { Those with } \\
\text { sawlog }\end{array}$ & $\begin{array}{c}\text { Those without } \\
\text { sawlog }\end{array}$ \\
\hline Sawlog & 66.8 & 100 & 0 \\
\hline Peeler & 13.2 & 8.7 & 22.4 \\
\hline Pulpwood & 56.3 & 50.6 & 67.8 \\
\hline Post & 1.4 & 0.8 & 2.7 \\
\hline Rail & 8.8 & 3.9 & 18.7 \\
\hline Scragg & 8.9 & 7.9 & 10.9 \\
\hline Firewood & 4.0 & 5.1 & 1.9 \\
\hline Waste & 25.4 & 27.3 & 21.6 \\
\hline
\end{tabular}

In terms of tree volume utilization, $58 \%$ of the total tree volume that was measured on the landing was merchandised as a sawlog. Pulpwood was the next highest product category produced on the landing with $20.2 \%$ of the total volume. The least merchandised product on the landing in terms of volume was post and firewood material at 1.1\% (Table 1.13).

Table 1.13. Percentage of total volume merchandised by product class during a 2008 harvest utilization study in West Virginia.

\begin{tabular}{lr}
\hline & \multicolumn{2}{c}{$\begin{array}{c}\text { Percent of total volume on } \\
\text { landing }\end{array}$} \\
\hline Sawlog & 58.0 \\
Peeler & 8.1 \\
Pulpwood & 20.2 \\
Post & 1.1 \\
Rail & 5.8 \\
Scragg & 3.3 \\
Firewood & 1.1 \\
Waste & 2.4 \\
\hline
\end{tabular}

The interaction between product merchandising and species showed that on average the red oak species group had the highest proportion of its volume being merchandised as sawlogs 
(79.8\%). This was followed by the black cherry $(74.1 \%)$ and white oak (71.6\%). Only $45.6 \%$ of the yellow-poplar group was merchandised as sawlogs, however, an additional $26.2 \%$ was devoted to peeler markets (Table 1.14).

Table 1.14. Percentage of total volume merchandised by product class and species group during a 2008 harvest utilization study in West Virginia

\begin{tabular}{lrrrrrrrr}
\hline Species Group & $\begin{array}{c}\text { Sawlog } \\
\text { Ch) }\end{array}$ & \multicolumn{1}{c}{$\begin{array}{c}\text { Peeler } \\
(\%)\end{array}$} & $\begin{array}{r}\text { Pulp (\%) } \\
\text { Chail (\%) }\end{array}$ & $\begin{array}{c}\text { Post } \\
(\%)\end{array}$ & $\begin{array}{c}\text { Firewood } \\
(\%)\end{array}$ & $\begin{array}{c}\text { Scragg } \\
(\%)\end{array}$ & $\begin{array}{c}\text { Waste } \\
(\%)\end{array}$ \\
\hline Hickory Spp. & 74.1 & 0.0 & 22.2 & 0.0 & 0.0 & 1.1 & 0.4 & 2.2 \\
Hard Maple & 52.2 & 0.0 & 45.4 & 0.0 & 0.0 & 0.0 & 0.0 & 2.4 \\
Mixed Hardwood & 71.2 & 0.0 & 17.3 & 0.0 & 0.0 & 2.2 & 8.5 & 0.8 \\
Pine Spp. & 48.3 & 0.0 & 37.4 & 0.0 & 1.8 & 0.1 & 10.6 & 1.8 \\
Red Oak & 37.3 & 0.0 & 8.7 & 35.7 & 14.9 & 0.5 & 0.0 & 2.9 \\
Soft Hardwood & 79.8 & 0.0 & 13.3 & 0.0 & 0.0 & 1.9 & 2.2 & 2.8 \\
Soft Maple & 38.3 & 14.4 & 31.7 & 0.0 & 0.0 & 0.0 & 12.0 & 3.6 \\
White Oak & 54.2 & 0.0 & 37.3 & 0.0 & 0.0 & 0.1 & 6.7 & 1.7 \\
Yellow-poplar & 71.6 & 0.0 & 17.9 & 1.5 & 0.0 & 3.5 & 2.7 & 2.8 \\
\hline
\end{tabular}

\section{Overall Utilization}

When the in-woods and landing utilization rates are combined, an overall utilization rate can be calculated for the harvests sampled. The overall utilization rate for the thirty harvests was $86.9 \%( \pm 11.8 \%)$. Again, the soft-hardwood species group had the lowest overall utilization rate followed by white oak. The pine group had the highest overall utilization rate, yellow-poplar had the second highest (Table 1.15). 
Table 1.15. Average overall utilization rate which combines both in-woods and landing utilization for species groups sampled on thirty timber harvests in West Virginia during 2008. Table sorted in descending order of utilization.

\begin{tabular}{lc}
\hline Species Group & Utilization (\%) \\
\hline Pine Spp. & 94.1 \\
Yellow-poplar & 89.3 \\
Cherry & 88.4 \\
Soft Maple & 87.5 \\
Hickory Spp. & 85.9 \\
Mixed Hardwood & 85.8 \\
Hard Maple & 84.6 \\
Red Oak & 84.5 \\
White Oak & 83.9 \\
Soft Hardwood & 76.9 \\
\hline
\end{tabular}

To meet assumptions of the parametric statistical tests used in the overall analysis, the total utilization rate was tested for normality. The Shapiro-Wilk hypothesis that total utilization was normally distributed was accepted $(p<0.06)$. Therefore, we assumed that the calculated utilization rate was representative of a normal distribution.

We found no relationships between the distance to individual markets and overall utilization on harvested sites. This was also true for pulpwood markets where the actual distance to the nearest market was calculated. This analyses also included those sites that had not delivered to each or any pulpwood markets.

Utilization rates on sites that had a forester involved versus those that didn't were not significantly different $(p=0.5850)$. Sites with a forester involved averaged $86.6 \%$ utilization versus $88.2 \%$ on sites without. There was a significant difference in utilization rate among logger types $(p=0.0112)$. Both independent $(88.5 \%)$ and contract $(88.3 \%)$ loggers had higher average utilization rates than company loggers (77.5\%). 
The utilization rate for companies that were fully mechanized versus those that were not did not differ $(p=0.1789)$. Likewise, no difference in overall utilization was found for those loggers with a high number of markets $(p=0.6320)$ or a high number of employees $(0.9412)$ than those with a lower number, respectively.

\section{Modeling Utilization Rate}

Model selection iteration performed using the AIC methodology produced a final model with 5 predictor variables: the ratio of the average smallest diameter to the average scaling diameter from the first piece for each tree measured on the landing (d-ratio), the percentage of yellow-poplar trees measured on the landing (ypstemp), the average scaling diameter of the first log from each tree (scaled), the total number of pieces merchandised (totpiece), and whether the loggers were fully mechanized (fullmec) (Table 1.16).

Table 1.16. Parameter average, standard deviation and range for variables included in model for predicting harvest utilization in West Virginia.

\begin{tabular}{lrrr}
\hline Parameter* & Mean (std) & Min & Max \\
\hline d-ratio & $0.60(0.11)$ & 0.40 & 0.83 \\
ypstemp & $0.27(0.32)$ & 0.0 & 0.96 \\
Scaled & $15.1(2.43)$ & 9.98 & 20.24 \\
totpiece & $111.27(29.34)$ & 54.0 & 173.0 \\
fullmec & $0.17(0.38)$ & 0.0 & 1.0
\end{tabular}

$*$ d-ratio: the ratio of the average smallest diameter to the average scaling diameter from the first piece for each tree measured on the landing, ypstemp: the percentage of yellow-poplar trees measured on the landing, scaled: the average scaling diameter of the first log from each tree, totpiece: the total number of pieces merchandised, fullmec: binary variable indicating whether the loggers were fully mechanized

The overall model developed using these predictors explained a significant amount of the variation in the total utilization rate $(P<0.0001)$. The $r$-square for this model was 0.85 and the mean error was $2.9 \%$. All parameter estimates were non-zero except for fullmec $(p=0.10)$. Because the parameter estimate for mechanization was not-significantly contributing to the model 
when analyzed alone, the model was rerun with the mechanization parameter removed. The new model was also highly significant $(p<0.0001)$. The $r$-square for the new model was 0.84 and the mean error was 3.0\%. Each of the remaining parameter estimates were non-zero for this model. The final model for predicting overall utilization rate took the form (Table 1.17):

Overall utilization $=1.31868-(0.48159 \times$ d-ratio $)+(0.06 \times$ ypstemp $)-(0.00837 \times$ scald $)-(0.00045379 \times$ totpiece $)$

Table 1.17. Final model parameter estimates and associated standard errors for predicting total harvest utilization rate in West Virginia.

\begin{tabular}{|c|c|c|c|c|}
\hline Variable $^{1}$ & DF & Parameter Estimate & Standard Error & $\operatorname{Pr}>t$ \\
\hline Intercept & 1 & 1.31868 & 0.04889 & $<0.0001$ \\
\hline d-ratio & 1 & -0.48159 & 0.05394 & $<0.0001$ \\
\hline ypstemp & 1 & 0.06046 & 0.01828 & 0.0028 \\
\hline scald & 1 & -0.00837 & 0.00250 & 0.0025 \\
\hline totpiece & 1 & -0.00045379 & 0.00020813 & 0.0389 \\
\hline
\end{tabular}

${ }^{1}$ d-ratio: the ratio of the average smallest diameter to the average scaling diameter from the first log for each tree measured on the landing. ypstemp: the percentage of yellow-poplar trees measured on the landing, scaled: the average scaling diameter of the first log from each tree, totpiece: the total number of pieces merchandised

\section{DISCUSSION}

As public interest in sustainability has increased, so has the importance of documenting the efficient use of our hardwood resource. This information is used to not only forecast the use of this resource but also to determine the amount of material that is available for new product markets and the overall efficiency of our industry.

In West Virginia, like other central Appalachian states, timber is harvested by loggers under contract with the timber owner, those that work directly for hardwood sawmills, and those that work independently. As in past studies (Alderman and Luppold 2005; Wang et al. 2007), we found that contract loggers were the most prevalent in $\mathrm{WV}$, followed by independents and company crews. Typically, contract loggers supply higher-value sawlogs on a per thousand board feet (MBF) basis to the contracting mill, and many times rely on markets for low-grade material to 
supplement their revenue. Company crews are normally on the payroll of hardwood sawmills and their main role is to supply the sawmill with raw materials. Independents function alone, with products moving to those facilities that will accept the product or to the highest bidder.

Those harvesting timber in West Virginia have access to a wide variety of markets. During the period of data collection, a wide number of markets, both inside and outside the state, were available to those producing roundwood products. These include hardwood grade and scragg mills, pulpwood facilities, two Oriented-strandboard facilities (OSB), a plywood veneer mill, an EWP structural product veneer mill, several rustic fence markets as well as a number of concentration yards for hard-hardwood pulp, sawlog and hardwood veneer-markets. The overall distribution and frequency of round markets can vary according to a number of factors. Roundwood markets typically develop based on the local species mixes as well as quality characteristics of the resource (Luppold, 2004). Other factors such as transportation efficiencies, companion industries, and governmental support can influence the development of markets over time. West Virginia has historically been a heavily forested state with a large variation in species mixtures as well as bole quality. In 2007 , the top ten tree species represented $71 \%$ of the total volume of live trees on forest land and the majority of the private forestlands were composed of trees in the largest stand size classes (Widmann et al. 2010).

At this time there are approximately 116 companies that purchase and or process roundwood materials in WV (Piva and Cook 2011). An even greater number exist outside WV but within acceptable trucking distances. Historically, the most important of these has been hardwood grade mills. This trend is still evident today. Although 9 different markets were identified, only sawmills were supplied by every contractor surveyed in this study. While there was no differentiation among types of sawmills, veneer mills, or pulpwood mills as in (Luppold 2004), all of the product markets that were identified had little overlap. Results are comparable to those of 
Alderman and Luppold (2005), who identified approximately ten WV roundwood markets and Wang et al. (2007) who identified nine of the same markets in a 2006 study and Wang et al. (2009) who identified seven markets. The average number of markets used per timber operator was slightly lower in this study than the Alderman and Luppold (2005) project (3.6 versus 4.0). This is probably due to the contraction in the overall WV forest products industry that continued through 2009. This can also be seen in the lower number of employees per crew and truckloads per day recorded in this project versus Wang et al. (2007). Likewise, the Alderman and Luppold (2005) study did not differentiate between those harvests with and without foresters. Our survey found that those sites with foresters averaged a higher number of markets than those without. It is possible that the harvests surveyed in the earlier paper had more forester involvement. While evidence does not exist linking foresters to a higher number of markets, research has shown that forester involvement can be beneficial to the landowner (Egan 1999).

Theoretically, the number of markets used by a logger could influence the manner in which the resource is harvested. As the number of available markets increase, one would expect the utilization rate to increase. This would be especially true if all markets were complementary and not competing. Less than half of the loggers surveyed delivered to the three top markets, which included sawlogs, OSB pulp, and pulpwood. The additional oversight by a forester only brought this ratio up to $50 \%$. When the next major market is considered (peelers), only $33 \%$ of those sampled delivered to these top 4 markets. Luppold and Alderman (2004) postulated that the type of logging crew explained much of the variation in product markets. They felt that independent loggers, should have access to more markets than contract and company loggers. However, they found similar results to this study. Independent loggers actually delivered to fewer product markets than contract and company loggers. Luppold and Alderman (2004) reasoned that this was due to two reasons. The first was the broad categorization of their product markets 
and the second was related to the terrain. WV is characterized by steep slopes which can limit the size of log landings and thus limit the room for product merchandising. While these are both true, in a randomly designed study, the impacts of these factors should be the same for all harvests visited. This is especially true for the product category breakdowns since the same categories were used for each harvest sampled. A more likely explanation is the fact that independent loggers would have access to fewer markets because of their limited ability to interact with these market players. Their overall lower production may limit their ability to work with a number of roundwood buyers. Forest products companies that hire contract loggers typically have several at any given time. Thus the amount of roundwood they can move would allow them to access many more markets. Each of the loggers under contract would benefit from these circumstances if all markets were used proportionate to their availability. However, in some cases market access could be restricted to contract loggers because the contracting mill could force loggers to focus on sawlog production at the expense of other products because the mill raw material needs.

Contrary to popular theory (Luppold and Alderman 2004), the highest value markets were also the closest markets in this study. The distance to sawmills was less than all other markets. Estimates from this project are similar to those of Luppold and Alderman (2004), the average distance to sawmills only increased by 4 miles over their findings. The distance to OSB pulp markets were also similar, however, the distance to the other pulpwood markets were approximately 20 miles greater in this study. Interestingly, the average distance to pulpwood markets was greater for those loggers not using them. This suggests that operators may have refrained from hauling to these markets as the distance increased beyond 70 miles. Typically, pulpwood buyers pay a premium for distance traveled, and when inventories are low add a production bonus to the base price. It is possible that pulpwood inventories were high during the 
time of this study and loggers working at greater distances from these facilities were not encouraged to make roundwood deliveries.

There is not a tremendous amount of data related to overall utilization of roundwood during harvest operations in the Appalachians. Probably the most extensive work has been conducted in the states of Virginia and North Carolina by the USDA Forest Service Southern Research Station. The in-woods utilization rate found for hardwoods in North Carolina was $79 \%$ (Bentley and Johnson 2006). In a similar study in Virginia, overall hardwood utilization was reported as $75 \%$ (Bentley and Johnson 2009). The lower level of utilization in these states could be the result of many factors; however, it does not appear to be market related. While both states have a more extensive industry base, they also have considerably higher softwood volumes than West Virginia and therefore one might expect markets for lower grade hardwood roundwood to be less important. This is not the case as evidenced in the Virginia study where 41 total softwood markets and 40 hardwood markets were identified (Bentley and Johnson, 2009). Other utilization reports have shown even lower levels. Wang et al (2009) measured whole stem utilization on 300 trees in WV. On a length basis, the utilization rate averaged $58.7 \%$. This is mainly due to the measurement of tree utilization with total tree height in the denominator, as well as the fact that it is on a length basis. Volumetric measures of utilization are much better because they give a better estimate of the actual material being used and left in the woods.

As would be expected, utilization rates on the landing were much higher than those found in the woods. Every piece of stem not used on the landing represents wasted time, fuel, and ultimately profitability for the logger. In West Virginia, the majority of stems are bucked for grade/value on the landing. Therefore, those sections not used on the landing were likely discarded because they reduced the value of the piece in question. Bucking productivity is also 
highly dependent on stem size and length (Wang 2006), which can also impact landing utilization rates.

In this project oak species had lower in-woods utilization rates than species with a more excurrent branching pattern such as pine spp. and yellow-poplar. Species specific utilization is also heavily dependent on the buck-off point in the woods. Both the pine species group and yellow-poplar had much smaller diameters at buck-off than the oaks. While markets also influence the utilization of these species, there were no direct relationships among distance to market and species specific utilization. Likewise, no relationship between overall utilization and markets was uncovered, this is similar to the results from previous studies where logging residue accumulations were investigated (Grushecky et al. 2007). Utilization rates were found to be even higher in this study when product category was considered. Sawlog sized material had an overall utilization rate of $94 \%$ in this project, which is the same as the North Carolina (Bentley and Johnson 2006) and lower than the Virginia (Bentley and Johnson 2009) studies which reported $94.1 \%$ and $96 \%$ utilization rates, respectively. The main reason the in-woods utilization rates were lower in the VA and NC studies is the pulpwood utilization rates. In VA, pulpwood utilization averaged $32 \%$, and in NC it averaged $18.5 \%$. These were both much lower than the $42.5 \%$ utilization rate found in this project. This would likely be due to the prevalence of hardwood pulp and other non-sawlog markets in West Virginia. This evidence is strengthened by the fact that over $80 \%$ of tree stems on the landing that did not have a sawlog removed were merchandised into three main secondary markets; pulpwood, peeler, and rail material.

The collection of utilization information is extremely time consuming and expensive. On a typical site, it takes three people 8-10 hours to collect information on thirty trees. At the time of this research, there had been no other documented attempt to predict total hardwood utilization from data that can be collected on the landing. Others have developed prediction equations to 
estimate the volume of logging residues left on site (Grushecky et al. 1998). Although these equations could be used as one step in a series to predict utilization, the errors associated with them are much larger than the equation presented here. Moreover, the collection of the information needed for the utilization equation presented also allows the investigator to collect both harvest and market characteristics. This would strengthen any inference being made in regard to utilization from a given harvest.

The equation presented will provide an estimate of utilization within three percent on average; however, it is important to note that prediction should only occur in areas where utilization rates fall within those sampled in this project. Likewise, the equation could be used to estimate utilization in other central Appalachian states; however, differences in markets, species mixes and other harvest characteristics would increase the level of error associated with the predictions. Use of the model developed here should reduce the resources necessary to a single, or at most 2 field workers, with a significant reduction in total data collection time.

Results from this project help frame the hardwood tree utilization on sites in West Virginia. Not only does this information provide estimates on the overall efficiency of harvest operations, but also allows for the determination of the characteristics and quantity of material being left after harvest. This information is not only important to those involved in the management of the hardwood resource, but also those that are making investments in wood processing industries. While the influence of markets and site characteristics did not explain a significant amount of the variation in overall utilization, we can assume from data collected in other states that the presence of non-sawlog markets can increase the utilization rate of pulpwood sized material. Further research on utilization rates in other hardwood producing states in the region would help strengthen the relationship between utilization and site characteristics. Likewise, similar data 
from other states would strengthen the prediction equation and allow those using it to have a better understanding of its predictive capacity.

\section{LITERATURE CITED}

Alderman, D. and W. Luppold 2005. Examination of regional hardwood roundwood markets in West Virginia. Forest Prod. J. 55(12):153-157.

Bentley, J.W. and T.G. Johnson. 2006. North Carolina harvest and utilization study, 2002. Resour. Bull. SRS-109. Asheville, NC:Department of Agriculture Forest Service, Southern Research Station. 23p.

Bentley, J.W. and T.G. Johnson. 2009. Virginia harvest and utilization study, 2007. Resour. Bull. SRS-163. Asheville, NC:Department of Agriculture Forest Service, Southern Research Station. 27p.

Blyth, J.E. and W. B. Smith 1979. Minnesota logging utilization factors. Resource Bulletin NC-48. St. Paul, MN: U.S. Dept. of Agriculture, Forest Service, North Central Forest Experiment Station, 8p:

Bozdogan, H. 1987. Model selection and Akaike's Information Criterion (AIC): The general theory and its analytical extensions. Psychometrika 52: 345-370

Egan, A.F. 1999. Reducing Forest Road Erosion: Do Foresters and Logging Contracts Matter? J. Forestry 97: 36-39.

Grushecky, S. T., C.C. Hassler and M.A. Fajvan 1998. Logging residue yield equations from West Virginia timber harvests. Northern J. of Appl. For. 15(1): 14-16.

Grushecky, S. T., C.C. Hassler, M.A. Fajvan and E.C. Murriner 1997. A survey of logging residues in West Virginia - 1995. Ag. And Forestry Exp. Sta. Bull. West Virginia University, 28p 
Grushecky, S. T., J. Wang and D.W. McGill 2007. Influence of site characteristics and costs of extraction and trucking on logging residue utilization in southern West Virginia. Forest Products Journal 57(7/8): 63-67.

Grushecky, S.T., D.W. McGill and R.B. Anderson 2006. Inventory of Wood Residues in Southern West Virginia. Northern J. of Appl. For. 23: 47-52.

Luppold, W., and M. Bumgardner. 2004. An examination of eastern U.S. hardwood roundwood markets. . Forest Prod. J. 54(12):203-208.

Schuler, A., R. Taylor and P. Araman 2001. Competitiveness of U.S. wood furniture manufacturers, lessons learned from the softwood moulding industry. Forest Prod. J. 51(7/8): 14-20.

Wang, J. 2006. Hardwood log bucking and loading efficiency in West Virginia. Forest Prod. J. 57(5):84-90.

Wang, J., T. Goff, J. McNeel and X. Zhao 2009. A field assessment of central Appalachian hardwood log bucking and merchandising practices. Forest Prod. J. 59(1/2):43-49.

Wang, J., S. T. Grushecky, Y. Li and J. McNeel 2007. Hardwood log merchandising and bucking practices in West Virginia. Forest Prod. J. 57(3):71-76.

Widmann, R.H., G.M. McCaskill, W. McWilliams and G.W. Cook. 2010. West Virginia's forest resources 2007. Res. Note NRS-60. Newtown Square, PA: U.S. Department of Agriculture, Forest Service, Northern Research Station . 5 p. 


\title{
Chapter 2: Economics of co-merchandising pulpwood to traditional and bioenergy markets in West Virginia.
}

\begin{abstract}
There has been renewed interest in determining the feasibility of pulpwood merchandising yards in the Appalachian region. Intensive merchandising has been seen as a potential way to supply raw material to bioenergy facilities at a lower cost. The feasibility of developing a hardwood pulpwood sorting merchandising yard in West Virginia was investigated. Over 377,000 pounds of pulpwood was procured for this project. The majority of the pulpwood purchased was red and white oaks (Quercus spp.). The merchandising operation resulted in negative net revenues for all species studied, handling cost was found to be one of the most important issues leading to this finding. However, it was found that merchandising low-quality sawlogs on the loglanding could be profitable. The cost and revenues reported in this paper represent a complex blend of pricing and product yields that are dynamic over time. As bioenergy markets expand and competition increases with traditional markets, inputs could be refined which would create a new set of merchandising options for roundwood.
\end{abstract}

\section{INTRODUCTION}

The availability of woody biomass in the Northeast has gained much attention in recent years because of the quest to replace fossil fuels with renewable energy sources. With recent surges in energy costs and higher costs expected in the future, roundwood harvested in the Appalachians has the potential to become important as a renewable fuel source for the future. Typically, the low-hanging fruit sought by energy entrepreneurs is either primary processing residues or logging residues. Virginia (Parhizkar and Smith 2008), Tennessee (Anonymous 2007) and West Virginia (Spong et al. 2009) have actively assessed the availability of primary processing 
residues in recent years. While primary processing residues represent a significant source of unused material, increased use by wood pellet and engineered product facilities has reduced their availability. Likewise, in West Virginia, substantial amounts of logging residues remain after harvesting (Grushecky et al. 2006). The lack of utilization may not be because of insufficient size, the average large and small end diameter of pieces measured was 9.2 and 4.9 inches, respectively, with an average length of 20.4 feet (Grushecky et al. 2006). The relatively large size of the logging residue remaining after harvest suggests that increased utilization of this resource may be possible. Traditional theory suggests that the markets themselves would influence logging residue utilization. However, data have not been collected that support this hypothesis (Grushecky et al. 2007).

While biomass markets, if established, would represent a good value stream for roundwood producers, it is not clear what price will be needed to facilitate increased utilization on harvested sites in WV. Currently, there are several markets for low-quality small diameter roundwood in West Virginia. These include markets for traditional pulp and paper production as well as for engineered wood products (EWP). Paper mills procuring roundwood in WV represent a significant market for roundwood pulpwood. Engineered product producers also procure high volumes of pulpwood; however, one drawback to these markets are their limited use of oak species in the production process. Currently, one producer will take up to $15 \%$ oak while others do not procure any.

One of the largest barriers to the increased extraction of logging residues is the cost. Small diameter roundwood must be extracted at the time of harvest or it will never "pay its way" out of the woods (Grushecky et al. 2007). One way to potentially increase the movement of logging residues is to source it concurrently with higher value products. Biomass feedstock or sort-yards have been gaining more attention as a potential means of generating profits for wood 
fiber producers (Anonymous 2009,Ciolkosz et al. 2010). Wu et al. (2010), considered the storage of logging residues on landings as an integral part of models developed estimating the delivered cost of biomass for bioenergy production in West Virginia.

Theoretically, a biomass concentration yard could help provide lower cost raw materials for bioenergy producers and traditional forest products producers by sharing sorting costs as well as always supplying higher value markets with appropriate materials. A biomass sort yard would function similarly to a traditional sort yard (Dram et al. 2004), except for the addition of new biobased product markets that would increase the number of merchandising decisions. The purchase of large diameter, low-defect sawlogs at such an operation would not be feasible because competition for this resource is intense making their procurement difficult. However, at $\$ 25-\$ 30 /$ ton, loggers have been supplying large amounts of pulpwood to paper and engineered products in $\mathrm{WV}$ for many years. Since a portion of this roundwood could easily meet low-grade sawlog specifications (Grushecky et al. 2006), it may present an opportunity to purchase pulpwood at market price and use the sawlogs that are merchandised to subsidize the cost of the

remaining fiber. Such a system could also increase the utilization of logging residues by providing a framework for increased utilization of this resource. Currently, the resulting product yields or margins are not known for such an operation. The objective of this research project was to determine whether an opportunity exists to merchandise logs of value from pulpwood and market remaining byproducts into traditional and/or new biomass markets.

\section{METHODS}

\section{Production Components}

Pulpwood was procured from several logging companies located in central West Virginia. Six tractor-trailer loads of hard-hardwood pulp (hickory, red, black, white, and chestnut oak) as well as four tractor-trailer loads of black cherry pulp were purchased directly from local loggers. 
This effectively diverted them from their original market destination (either engineered product or pulping facilities). Although roundwood pulpwood specifications may vary somewhat with geographic region, the following specifications for pulpwood were used for this study: a minimum 4-inch diameter to about a 28 -inch diameter and roughly 8 to 24 feet in length. These specifications were directly related to the pulpwood markets available to the loggers used in this study.

Once unloaded, the pulpwood was merchandised using a high-lift and mechanically bucked using a chainsaw. Crew members were trained and assisted in merchandising/bucking techniques by a primary processing facility owner with more than 30 years of log buying experience. Each section of pulpwood was evaluated for the potential to merchandise one or more sawlogs from that piece. Merchandising resulted in three product types: sawlogs, pulpwood, and firewood. Firewood included merchandised pieces that did not meet the minimum pulpwood specification. A minimum sawlog diameter was maintained for each species, with the oaks and hickory limited to an 8-inch minimum diameter and the black cherry to a 6-inch minimum diameter. These diameter limits were developed based on interaction with the local industry and our sawmill cooperator. All sawlogs were merchandised in standard lengths of 8 , $10^{\prime}, 12^{\prime}, 14^{\prime}$, and $16^{\prime}$, but also included both 6- and 7- foot logs in an attempt to take advantage of any Select lumber that might result. Each pulpwood piece was numbered, with each merchandised piece designated with the piece number and a letter $(A, B, C$, or $D)$. All pieces were weighed, with diameters and length recorded for each piece. The position (butt or upper), number of clear sides, scaling defects (Rast 1973), and end condition (double heart, stain, shake, mineral, split, and interior/sector cull) was recorded for each sawlog merchandised.

The sawlogs were then transported to the sawmill for processing. The mill consisted of a circle headrig with a live deck, hydraulic log-turner, and pneumatic dogs; an edger; and a chop 
saw for trimming. The circle saw configuration was chosen to represent a worst-case scenario with regard to saw kerf. Each log was sawn, and the lumber and cant products recorded by species and log number. All lumber was graded according to standard NHLA lumber grading rules, and cants were sawn into $4^{\prime}, 6^{\prime}, 8^{\prime}, 10^{\prime}$, or $12^{\prime}$ lengths and as either $5.5^{\prime \prime} \times 6^{\prime \prime}$ or as $4^{\prime \prime} \times 6^{\prime \prime}$. Because of the larger proportion of small diameter sawlogs, tie and timber products were not included in the product mix.

Resulting data were standardized to a per thousand board feet (MBF) of lumber and cant products basis. The following formula was the basis for determining profitability of the merchandising options:

$$
\mathrm{NR}=\mathrm{RL}+\mathrm{RPW}+\mathrm{RSR}-\mathrm{CPW}-\mathrm{CH}-\mathrm{CS}
$$

Where,

$\mathrm{NR}=$ net revenue per thousand board of lumber and cant products produced (\$);

$\mathrm{RL}=$ lumber and cant revenue (\$);

RPW =net residual pulpwood revenue, following merchandising (\$);

RSR=net residual sawmill residue revenue, including bark, sawdust and chips (\$);

CPW=roundwood pulpwood cost (\$);

$\mathrm{CH}=$ handling/merchandising cost (\$); and

$\mathrm{CS}=$ sawing cost to produce the lumber and cant products $(\$)$.

Lumber and cant revenue (RL) is based on lumber grade yields of the logs and the selling price of the products sawn. The revenue from one MBF of lumber and cants produced was 
determined by applying the lumber grade yields to one MBF and multiplying that yield by the product prices.

The economic feasibility of merchandising pulpwood for sawlogs is highly dependent upon the prices received for the lumber and cant products produced. As prices change over time, the economic feasibility can change. So, one logical approach is to select prices that are at or near their recent historic lows. Then, if economic feasibility can be achieved, one can be reasonably sure that merchandising remains a viable alternative. For the purposes of this study, pricing is based on Hardwood Market Report (HMR 2009) prices for December 2009, which were at or near the bottom of hardwood pricing over the last decade (Table 2.1).

Table 2.1. Lumber (4/4) and cant prices ( $\$ /$ thousand board feet) delivered to receiving mill used in the analysis of merchandising pulpwood into sawlogs, by species (HMR 2009).

\begin{tabular}{|c|c|c|c|c|}
\hline \multirow[b]{3}{*}{ Lumber Grade } & \multicolumn{4}{|c|}{ Species } \\
\hline & & & & White Oak/ \\
\hline & Hickory & Red Oak/Black Oak & Black Cherry & Chestnut Oak \\
\hline FAS & 615 & 805 & 1,530 & 900 \\
\hline One Face & 605 & 795 & 1,520 & 890 \\
\hline Select & 595 & 785 & 1,510 & 880 \\
\hline No. $1 \mathrm{Com}$ & 500 & 560 & 625 & 540 \\
\hline No. 2a Com & 350 & 460 & 320 & 365 \\
\hline No. $2 \mathrm{~b}$ Com $^{*}$ & 150 & 150 & 150 & 150 \\
\hline No. 3a Com & 200 & 385 & 255 & 305 \\
\hline No. $3 \mathrm{~b} \mathrm{Com}^{*}$ & 150 & 150 & 150 & 150 \\
\hline Below Grade* & 150 & 150 & 150 & 150 \\
\hline Cant & 325 & 325 & 325 & 325 \\
\hline
\end{tabular}

*Note: the below grade boards are assumed to be sold as pallet stock, as are the No. $2 \mathrm{~b}$ Common and No. $3 \mathrm{~b}$ Common boards, given that these two Common grades are based on sound cuttings as opposed to clear cuttings.

Roundwood pulpwood cost (CPW) is determined from the total weight of pulpwood that must be purchased in order generate one thousand board feet of lumber and cant products. This is based on the lumber and cants sawn from a ton of sawlogs and the weight of roundwood pulpwood required to generate this one thousand board feet of lumber and cants. The 
relationship used to generate the tons of pulpwood needed to produce $1 \mathrm{MBF}$ of product takes the form;

$$
\text { Tons pulp to produce MBF }=\frac{\text { Pulpwood WGT }(l b s) \times 1000(b f)}{\text { Lumber }(b f) \times 2000\left(\frac{l b s}{t o n}\right)}
$$

Where Pulpwood WGT is the weight of pulpwood (lbs) required to produce a given board feet of lumber (Lumber). This equation simplifies to the form:

$$
\text { Tons pulp to produce MBF }=\frac{\text { Pulpwood } W G T(l b s)}{\text { Lumber }(b f) \times 2}
$$

To calculate the weight of sawlogs needed to produce a MBF, the same formula can be used by substituting sawlog weights for pulpwood weights. A base assumption of $\$ 25$ per ton of pulpwood delivered to the merchandising site was made, which is compatible with base pulpwood pricing in the mid-Atlantic region. As distance from the receiving mill increases, this price could increase by several dollars per ton to account for the additional trucking cost. However, it was assumed that the merchandising yard is sufficiently distant from the fiber-receiving mill that many suppliers working at any given time in the area of the merchandising yard will find it more costeffective to deliver their pulpwood to the merchandising yard rather than incur additional trucking expenses in transporting it to the fiber-receiving mill. In large part, this is assumed to be a result of loggers taking advantage of the opportunity to gain at least one additional load per day (albeit at an equal or lower price) to the merchandising yard, as opposed to trucking the pulpwood to the more distant destination of the fiber-consuming mill. Of course, operators in other regions 
will certainly work under a different pricing structure for pulpwood, which should be considered when evaluating any merchandising opportunity.

Net residual pulpwood revenue (RPW) is the weight of residual pulpwood and firewood pieces following merchandising multiplied by the delivered price per ton less the cost of trucking. A net delivered price of $\$ 20$ per ton was used for RPR based on the assumption that the residual pulpwood being delivered to the fiber-consuming mill from the merchandising yard would be paid an additional premium for trucking distance, but must incur a truck delivery charge. Estimating RPR is difficult because of the various trucking distance and pricing scenarios that could be encountered. It was also assumed that firewood-sized residuals would generate at least the value of the roundwood pulpwood residuals.

Net residual sawmill residue revenue (RSR) is based on Massengale's (1971) study of residue weights, by scaling diameter, of mixed oak logs in the Missouri Ozarks. The 8-foot and 10-foot log data, over the applicable range of diameters, was aggregated to estimate the percentage of log weight in bark, sawdust, and chips. On a percentage basis, bark, sawdust, and chips represent 12 percent, 20 percent, and 23 percent, respectively, of total sawlog weight. Selling price per ton of these residual products is assumed to be net of trucking cost (i.e., FOB sawmill) and are $\$ 8, \$ 10$, and $\$ 10$ per ton for sawdust, bark, and chips, respectively. These prices were obtained during the study period from forest products industry cooperators. With increasing demand from bioenergy markets in the Appalachian region, these prices should be considered a conservative estimate.

A $\$ 5$ per ton handling/merchandising $(\mathrm{CH})$ cost was used to cover a knuckleboom loader, sawbuck, and front-end loader for merchandising and handling sawlogs. This value was generated through interaction with local mills and is comparable to handling costs found in the 
literature. Wang (2007) determined that loading and bucking costs averaged $\$ 23.94 / \mathrm{MBF}$, which is approximately $\$ 3.68$ per ton.

A sawing cost (CS) of $\$ 200 / \mathrm{MBF}$ was used for the mill tally of lumber and cants produced. This value included operating costs as well as the trucking cost to move the products to market. Sawing cost was obtained from project cooperators, being the same cost used for business accounting purposes. The various pricing assumptions presented here have been selected to be conservative, so as not to lead the reader to a set of incorrect conclusions in the event that the price assumptions change.

\section{Sawlog profitability}

The ultimate goal of such an operation is to merchandise as many profitable sawlogs as possible. Logistic regression was used to examine the attributes influencing the probability of sawlogs having sufficient value per ton to encourage merchandising. Using the lumber and weight information collected for each sawlog, value per ton can be calculated as:

$$
\frac{\left(\left(\sum_{1}^{n}(L L G \times L G P)\right)-(T L \times C S / \text { Board Foot })\right) * 2000 \mathrm{lbs} / \text { ton }}{W G T}
$$

Where,

$\mathrm{n}=$ number of lumber grades sawn for each $\log$,

LLG $=$ lumber sawn for the $\mathrm{n}^{\text {th }}$ lumber grade (board foot),

$\mathrm{LGP}=$ market price for the $\mathrm{n}^{\text {th }}$ lumber grade $(\$ /$ board foot $)$,

$\mathrm{TL}=$ total lumber sawn for a $\log (\mathrm{bf})$,

$\mathrm{CS}=$ sawing cost of lumber and cants ( $\$ 0.20 /$ board foot), and

WGT = sawlog weight (lbs). 
Again, a value of $\$ 200 / \mathrm{MBF}$ ( $\$ 0.20 / \mathrm{bf})$ was used to represent log sawing costs. For the logistic analyses, the dichotomous outcome variable was selected based on a log value of $\$ 30.00$ /ton. Logs were considered profitable if their value/ton was greater than $\$ 30.00$. This number was chosen based on the base pulp pricing structures common in the region, logs with values greater than $\$ 30 /$ ton would be worth more in lumber than pulp markets. The probability to be profitable $P$ was modeled as follows:

$$
\ln \left[P_{i} /\left(1-P_{i}\right)\right]=\beta_{0}+\beta X_{1}+\beta X_{2}+\beta X_{3}+\beta X_{4}+\beta X_{5}+\beta X_{6}
$$

Where:

$$
\begin{aligned}
& \ln \left[P_{i} /\left(1-P_{i}\right)\right]=\text { the log of the odds ratio } \\
& \beta_{0}=\text { intercept term } \\
& \beta X_{1}=\text { coefficient and explanatory variable for species } \\
& \beta X_{2}=\text { coefficient and explanatory variable for scaling diameter } \\
& \beta X_{3}=\text { coefficient and explanatory variable for sawlog position in tree (butt or upper) } \\
& \beta X_{4}=\text { coefficient and explanatory variable for clear sides (\# of clear log faces) } \\
& \beta X_{5}=\text { coefficient and explanatory variable for end (condition of log ends) } \\
& \beta X_{6}=\text { coefficient and explanatory variable for scaling deduction (combination of cull, } \\
& \text { internal, sweep, and crook defects) }
\end{aligned}
$$

Forward selection was used to reduce the dimension of the original model, using the likelihood ratio test to calculate significance levels (Freund and Littell 2000). Since variables not significant at $a=0.05$ could still be associated with the outcome after adjusting for the other variables, any factors with univariate results of $P<0.25$ were considered eligible for entrance into 
the model. Each eligible factor was then tested against the reduced model. Only those factors significant at $\mathrm{P}<0.05$ were included in the final model.

\section{Reclassifying sawlogs}

To further understand the impact of sawlog merchandising on overall profitability, iterative analyses were done to determine the influence of removing less profitable sawlogs and re-running the overall profitability analyses. For each species, sawlogs were removed from the analyses and recoded as pulpwood based on their gross value per ton. Analyses were rerun and the impact on net revenue was evaluated. Sawlogs were separated based on values per ton less than $\$ 0$ $\$ 50 /$ ton in $\$ 5 /$ ton increments.

\section{RESULTS}

\section{Production Components}

A total of 740 pulpwood pieces were procured and merchandised, where possible, into sawlogs. This included over four hundred pieces of oak species and 258 pieces of black cherry (Table 2.2). 
Table 2.2. Characteristics of pulpwood merchandised in West Virginia.

\begin{tabular}{|c|c|c|c|c|c|c|c|c|}
\hline $\begin{array}{l}\text { Species } \\
\text { group* }\end{array}$ & $\begin{array}{l}\text { No. full } \\
\text { length } \\
\text { pieces }\end{array}$ & $\begin{array}{l}\text { Weight of } \\
\text { full length } \\
\text { pieces (lbs) }\end{array}$ & $\begin{array}{c}\text { No. } \\
\text { sawlogs }\end{array}$ & $\begin{array}{c}\text { Sawlog } \\
\text { weight } \\
\text { (lbs) }\end{array}$ & $\begin{array}{c}\text { No. } \\
\text { residual } \\
\text { pulpwood } \\
\text { pieces }\end{array}$ & $\begin{array}{l}\text { Weight of } \\
\text { residual } \\
\text { pulpwood } \\
\text { (Ibs) }\end{array}$ & $\begin{array}{c}\text { No. } \\
\text { residual } \\
\text { firewood } \\
\text { pieces }\end{array}$ & $\begin{array}{l}\text { Weight of } \\
\text { residual } \\
\text { firewood } \\
\text { (lbs) }\end{array}$ \\
\hline Hickory & 42 & 32,269 & 37 & 23,222 & 16 & 7,203 & 7 & 1,844 \\
\hline Red Oak & 176 & 107,855 & 101 & 47,085 & 108 & 50,939 & 40 & 9,831 \\
\hline Black Cherry & 258 & 84,720 & 211 & 39,221 & 144 & 33,856 & 113 & 11,643 \\
\hline White Oak & 264 & 152,488 & 166 & 72,463 & 160 & 65,656 & 71 & 14,369 \\
\hline Totals & 740 & 377,332 & 515 & 181,991 & 428 & 157,654 & 231 & 37,687 \\
\hline
\end{tabular}

The total weight of all the roundwood pulpwood procured for this project was 377,332 pounds or 188.7 tons. Of that total, 181,991 pounds (90.9 tons) or 48.2 percent was merchandised into sawlogs. By species, 71.9 percent of hickory, 43.7 percent of red oak/black oak, 46.3 percent of black cherry, and 47.5 percent of white oak/chestnut oak were merchandised into sawlogs. The average scaling diameter was greatest for hickory species, followed by oak species (Table 2.3). 
Table 2.3. Characteristics of sawlogs merchandised from roundwood pulpwood, by species.

\begin{tabular}{|c|c|c|c|c|c|c|}
\hline Species* & $\begin{array}{l}\text { Converted to } \\
\text { Sawlogs (\%) }\end{array}$ & $\begin{array}{l}\text { Avg. log diam. } \\
\text { (in) }\end{array}$ & $\begin{array}{l}\text { Avg. log len. } \\
\text { (ft) }\end{array}$ & $\begin{array}{l}\text { Avg. clear } \\
\text { sides }\end{array}$ & Butt logs (\%) & $\begin{array}{l}\text { Avg. Doyle } \\
\text { Vol. (bf) }\end{array}$ \\
\hline Hickory & 71.7 & 11.2 & 10.2 & 1.8 & 23.3 & 32.5 \\
\hline Red Oak & 43.7 & 9.7 & 9.7 & 1.4 & 5.9 & 19.3 \\
\hline Black Cherry & 46.3 & 8.6 & 8.0 & 1.2 & 3.3 & 9.7 \\
\hline White Oak & 47.5 & 9.6 & 9.6 & 1.3 & 6.6 & 18.5 \\
\hline
\end{tabular}

* Hickory includes all hickories (Carya spp.); red oak includes red (Quercus rubra), black (Quercus velutina), and scarlet (Quercus coccinea) oaks; white oak includes white (Quercus alba) and chestnut (Quercus prinus) oaks

The total footage of lumber and cants sawn for hickory was $1715.5,3,445$ for red oak/black oak; 2,829.7 for black cherry; and 5,367.8 board feet for white oak/chestnut oak. At most, about eight percent of the resulting lumber met Select and better specifications (Table 2.4), which was found for hickory. The majority of the lumber produced was for industrial products.

Table 2.4. Percentage lumber grade yields for sawlogs merchandized from pulpwood, by species.

\begin{tabular}{lccrr}
\hline $\begin{array}{l}\text { Lumber Grade and } \\
\text { Overrun }\end{array}$ & \multicolumn{3}{c}{$\begin{array}{c}\text { Species* Grade Yield Percentage } \\
\text { Bed oak }\end{array}$} & \multicolumn{2}{c}{ Black cherry } & White oak \\
\hline FAS & 1.2 & 1.6 & 0.0 & 0.3 \\
One Face & 6.6 & 2.3 & 0.3 & 1.1 \\
Select & 0.0 & 0.0 & 0.4 & 0.5 \\
No. 1 Com & 18.0 & 8.7 & 6.3 & 3.5 \\
No. 2a Com & 13.9 & 13.1 & 10.5 & 11.2 \\
No. 2b Com & 1.0 & 0.3 & 0.0 & 0.5 \\
No. 3a Com & 0.0 & 1.2 & 1.3 & 3.9 \\
No. 3b Com & 0.0 & 0.1 & 0.0 & 1.7 \\
Below Grade & 0.9 & 0.2 & 47.0 & 0.3 \\
Cant & 58.4 & 72.5 & 34.2 & 77.0 \\
\hline * Hickory includes all hickories (Carya spp.); red oak includes red (Quercus rubra), black (Quercus velutina), and \\
scarlet (Quercus coccinea) oaks; white oak includes white (Quercus alba) and chestnut (Quercus prinus) oaks
\end{tabular}


The required tonnage of pulpwood needed to produce a thousand board feet of lumber was lowest for the hickory pulpwood. Red and white oaks, as well as black cherry were fairly even in the amount of pulpwood needed to produce one MBF of lumber. The weight of sawlogs needed to produce an MBF of lumber was similar for all species (Table 2.5).

Table 2.5. Board footage sawn per ton of sawlogs, tonnages of sawlogs required to produce one thousand board feet of lumber and cants, and tonnages of pulpwood required to produce one thousand board feet of lumber and cants, by species.

\begin{tabular}{lrrrr}
\hline & \multicolumn{2}{c}{ Species* } \\
& Hickory & Red Oak & Black Cherry & White Oak \\
\hline Board footage per ton of sawlog & 147.8 & 146.3 & 144.3 & 148.2 \\
Tons sawlogs needed for 1 MBF lumber & 6.8 & 6.8 & 6.9 & 6.7 \\
Tons pulpwood needed for 1 MBF lumber & 9.4 & 15.7 & 14.9 & 14.2 \\
\hline * Hickory includes all hickories (Carya spp.); red oak includes red (Quercus rubra), black (Quercus velutina), and \\
scarlet (Quercus coccinea) oaks; white oak includes white (Quercus alba) and chestnut (Quercus prinus) oaks
\end{tabular}

\section{Cost Components}

Using the former results, the total cost for merchandising pulpwood was calculated. Total costs ranged from a high of almost $\$ 670$ per MBF for red oak to a low of $\$ 482$ for hickory (Table 2.6). On average, the cost of procuring the pulpwood represented 57 percent and the sawing cost represented 33 percent of the total cost to produce an MBF of lumber. 
Table 2.6. Component costs for merchandising roundwood pulpwood into sawlogs and lumber and cant products, by species. All costs in terms of dollars per thousand board feet (\$/MBF).

\begin{tabular}{lrrrr}
\hline & \multicolumn{3}{c}{ Species* } \\
& Hickory & Red Oak & Black Cherry & White Oak \\
\hline Cost of roundwood pulpwood & $\$ 253.13$ & $\$ 391.35$ & $\$ 374.25$ & $\$ 355.00$ \\
Cost of merchandising & $\$ 47.03$ & $\$ 78.27$ & $\$ 74.85$ & $\$ 71.00$ \\
Sawing cost per MBF lumber and cants & $\$ 200.00$ & $\$ 200.00$ & $\$ 200.00$ & $\$ 200.00$ \\
Total cost to produce one MBF of lumber and cant & $\$ 482.16$ & $\$ 669.62$ & $\$ 649.10$ & $\$ 626.00$ \\
\hline * Hickory includes all hickories (Carya spp.); red oak includes red (Quercus rubra), black (Quercus velutina), and \\
scarlet (Quercus coccinea) oaks; white oak includes white (Quercus alba) and chestnut (Quercus prinus) oaks
\end{tabular}

\section{Revenue Components}

The residual pulpwood revenue is more straightforward than the revenue portion of the merchandising equation. Residual pulpwood revenue is the difference between the total roundwood purchased and the sawlog weight multiplied by the net revenue received per ton of residual pulpwood. Red oak species had the highest residual pulpwood revenue at $\$ 176.40$, followed by black cherry, white oak species, and hickory species at $\$ 160.80, \$ 149.00$, and $\$ 52.74$, respectively.

The next source of revenue is sawing byproducts (bark, dust, and chips), which represent the second largest component of non-sawlog revenue. Because the same yields per MBF and prices per ton were used for each species, the only variability in net revenue for sawing byproducts is due to the weight needed to saw $1 \mathrm{MBF}$ for each species (Table 2.7). Chips from slabs and edgings had the highest net revenue for sawing byproducts followed by sawdust and bark for each species, respectively. 
Table 2.7. Revenue per thousand board feet from sawmill residues, including bark, sawdust, and chips. Net revenue is based on the weight of sawlogs required to saw $1 \mathrm{MBF}$, the percent byproduct per ton and the price per ton for each sawing byproduct.

\begin{tabular}{|c|c|c|c|c|}
\hline & \multicolumn{4}{|c|}{ Species* } \\
\hline & Hickory & Red Oak & Black Cherry & White Oak \\
\hline \multicolumn{5}{|l|}{ Bark } \\
\hline Price per ton & $\$ 8.00$ & $\$ 8.00$ & $\$ 8.00$ & $\$ 8.00$ \\
\hline Net revenue & $\$ 6.50$ & $\$ 6.56$ & $\$ 6.65$ & $\$ 6.48$ \\
\hline \multicolumn{5}{|l|}{ Sawdust } \\
\hline Price per ton & $\$ 10.00$ & $\$ 10.00$ & $\$ 10.00$ & $\$ 10.00$ \\
\hline Net revenue & $\$ 13.54$ & $\$ 13.67$ & $\$ 13.86$ & $\$ 13.50$ \\
\hline \multicolumn{5}{|l|}{ Chips } \\
\hline Price per ton & $\$ 10.00$ & $\$ 10.00$ & $\$ 10.00$ & $\$ 10.00$ \\
\hline Net revenue & $\$ 15.57$ & $\$ 15.72$ & $\$ 15.94$ & $\$ 15.53$ \\
\hline
\end{tabular}

The final component of revenue is the value associated with lumber and cants produced from the merchandised sawlogs (Table 2.8). Red oak sawlogs had the highest net revenue per MBF followed by hickory and white oak. 
Table 2.8. Lumber and cant revenues per thousand board feet for sawlogs merchandised from pulpwood in West Virginia. Missing values indicate lumber grades not sawn from merchandised logs.

\begin{tabular}{lrrrr}
\hline & & \multicolumn{2}{c}{ Species $^{1}$} & \\
Lumber Grade & & & \\
& Hickory & Red Oak/Black Oak & Black Cherry & White Oak/Chestnut Oak \\
\hline FAS & $\$ 7.38$ & $\$ 12.88$ & --- & $\$ 2.70$ \\
One Face & $\$ 39.93$ & $\$ 18.29$ & $\$ 4.56$ & $\$ 9.79$ \\
Select & --- & -- & $\$ 6.04$ & $\$ 4.40$ \\
No. 1 Com & $\$ 90.00$ & $\$ 48.72$ & $\$ 39.38$ & $\$ 18.90$ \\
No. 2a Com & $\$ 48.65$ & $\$ 60.26$ & $\$ 33.60$ & $\$ 40.88$ \\
No. 2b Com & $\$ 1.50$ & $\$ 0.45$ & -- & $\$ 0.75$ \\
No. 3a Com & --- & $\$ 3.32$ & $\$ 11.90$ \\
No. 3b Com & --- & --- & $\$ 2.55$ \\
Below Grade & $\$ 1.35$ & $\$ 0.15$ & $\$ 0.45$ \\
Cant & $\$ 189.80$ & $\$ 0.30$ & $\$ 111.15$ & $\$ 250.25$ \\
Total Revenue & $\$ 378.61$ & $\$ 381.30$ & $\$ 342.57$ \\
\hline${ }^{1}$ Hickory includes all hickories (Carya spp.); red oak includes red (Quercus rubra), black (Quercus velutina), and \\
scarlet (Quercus coccinea) oaks; white oak includes white (Quercus alba) and chestnut (Quercus prinus) oaks \\
${ }^{2}$ As specified by the National Hardwood Lumber Association (http://nhla.com)
\end{tabular}

Net revenues were negative for each species merchandised during this study. Hickory was the closest to breaking even, followed by the red oak species group (Table 2.9). The red oak group had the highest total cost for producing one MBF of hardwood lumber at $\$ 669$. Hickory spp. had the lowest total cost. 
Table 2.9. Net revenues generated by merchandising pulpwood into sawlogs in West Virginia.

\begin{tabular}{|c|c|c|c|c|}
\hline & & & ecies* & \\
\hline & & Red Oak/ & & White Oak/ \\
\hline & Hickory & Black Oak & Black Cherry & Chestnut Oak \\
\hline Total cost to produce one ME & & & & \\
\hline roundwood pulpwood & $\$ 482.16$ & $\$ 669.62$ & $\$ 649.10$ & $\$ 626.00$ \\
\hline Total revenue resulting from & & & & \\
\hline production of one $\mathrm{MBF}$ from & $\$ 466.96$ & $\$ 593.65$ & $\$ 465.80$ & $\$ 527.08$ \\
\hline roundwood pulpwood & & & & \\
\hline Net revenue per $\mathrm{mbf}$ & $(\$ 15.20)$ & $(\$ 75.95)$ & $(\$ 183.30)$ & $(\$ 98.92)$ \\
\hline
\end{tabular}

\section{Sawlog profitability}

Total revenue on a per ton basis was greatest for red oak logs followed by hickory, white oak and black cherry respectively (Table 2.10). A total of 64 logs of all species were coded as profitable (Value> $\$ 30.00 /$ ton) in the logistic analyses.

Table 2.10. Average value on a per ton basis for sawlogs merchandised from pulpwood.

\begin{tabular}{lrr}
\hline Species group & No. Logs & Value/ton (standard dev.) \\
\hline Red Oak & 101 & $\$ 26.00( \pm \$ 8.60)$ \\
Hickory & 37 & $\$ 25.22( \pm \$ 8.11)$ \\
White Oak & 166 & $\$ 21.02( \pm \$ 7.37)$ \\
Black Cherry & 211 & $\$ 7.58( \pm 15.16)$ \\
\hline
\end{tabular}

Because of its net revenue levels in the overall profit analyses, hickory was chosen as the reference for species comparisons. Univariate results indicated that an increased likelihood of log profitability was associated with species $(p=0.0002)$, scaling diameter $(p<0.0001)$, clear sides $(p<0.0001)$, and scaling deductions $(p=0.0252)$ since each significantly impacted the odds of a given sawlog being profitable. All were positive effects, except for scaling defects which was 
negative (Table 10). These were the only factors that met the criteria $(P<0.25)$ for entering the forward selection process.

Of the variables assessed in the logistic analysis, the odds ratio for the comparison of red oak versus hickory was the greatest at 3.21 (Table 2.11). This was followed by the association of profitability with the number of clear sides and scaling diameter. Results from this analysis suggest that red oak logs with a larger scaling diameter and greater number of clear sides are the most profitable in terms of value generated per ton. Individually, for every inch increase in scaling diameter, the likelihood of being profitable increased by 1.8 times. Similarly, as the number of clear sides increased, the likelihood of profitability increased 1.9 times. Although significant, scaling deductions had little practical influence on profitability likelihood, only decreasing it by 0.008 times for each unit increase in deduction.

Table 2.11. Proportional odds ratios for species effects and other predictor variables included in logistic regression model.

\begin{tabular}{lrr}
\hline Effect & \multicolumn{2}{c}{$\begin{array}{c}95 \% \text { Wald } \\
\text { Confidence Limits }\end{array}$} \\
\hline Black Cherry vs. Hickory & 1.22 & $0.37-3.97$ \\
Red Oak vs. Hickory & 3.21 & $1.13-9.13$ \\
White Oak vs. Hickory & 0.54 & $0.19-1.56$ \\
Scaling Diameter & 1.79 & $1.41-2.27$ \\
No. Clear Sides & 1.89 & $1.46-2.43$ \\
Scaling Deductions & 0.008 & $.001-0.37$ \\
\hline
\end{tabular}

The breakeven log costs for the red oak species group was the highest at $\$ 321.15 / \mathrm{MBF}$. Both white oak and hickory species had similar breakeven log costs when merchandising variables were ignored and only log profitability was evaluated at $\$ 255.62$ and $\$ 254.34$, respectively. Break even log costs for black cherry were much lower at $\$ 126.01 / \mathrm{MBF}$. At a $10 \%$ profit level, white oak sawlogs would have to be purchased at $\$ 200.67 / M B F$, hickory at $\$ 205.31 / M B F$, and red 
oak at $\$ 259.80$. In order to achieve a $10 \%$ profit level for black cherry logs, they would have had to be purchased at $\$ 89.40 / \mathrm{MBF}$.

\section{Reclassifying sawlogs}

Due to sample sizes, only red oak, white oak, and black cherry species were used in the reclassification iterations. Results obtained when sawlogs were classified based on their gross value/ton showed an almost exponential decline in net revenue for each of the species analyzed. White oak net revenue declined drastically after $\$ 15 /$ ton, followed by black cherry at $\$ 20 /$ ton and red oak at the $\$ 25 /$ ton (Figure 2.1). The main reason for the large decline in net revenue is the impact of handling. The greater the value of sawlogs an operator searches for becomes, the greater the number of pieces that need to be handled.

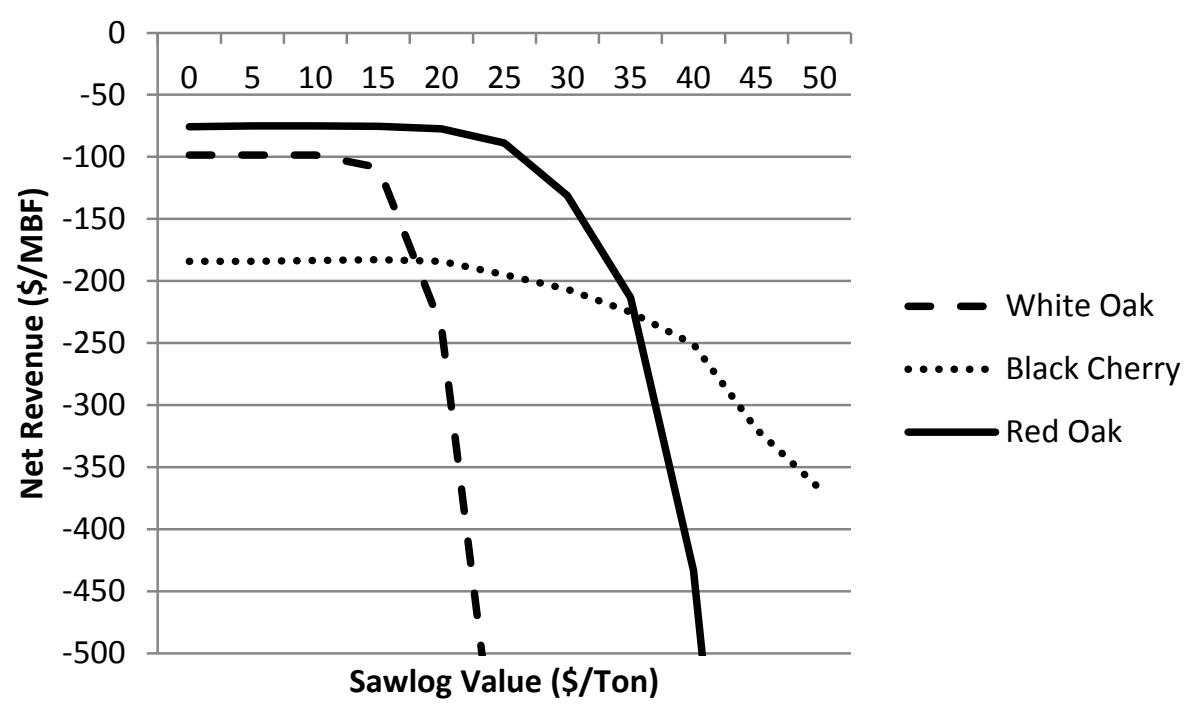

Figure 2.1. Results from iterative analyses where sawlogs with given values/ton ( $X$ axis) were removed from the analyses and recoded as pulpwood based on their gross value per ton. Analyses were rerun and the impact on net revenues ( $Y$ axis) were evaluated. Sawlogs were separated based on values per ton less than $\$ 0-\$ 50 /$ ton in $\$ 5 /$ ton increments. 


\section{DISCUSSION}

Log cost, utilization, supply, and markets are several of the factors that influence the potential profitability of a roundwood sort yard in West Virginia. Theoretically, sort yards could help provide a uniform log resource and ensure that roundwood is directed to the highest value markets (Dramm et al. 2002). Likewise, the development of new bioenergy markets will necessitate the movement of higher value roundwood in order to obtain raw materials at lower price levels. Increasing the profitability of merchandising operations can be achieved through a combination of lowering costs and raising values of final products (Dramm et al. 2004). Costs can be lowered through efficient yard layouts, minimized handling, and minimized effort in processing. Value increases can result from improved log markets and raw material product mixes and improved log bucking practices (Dramm et al. 2004).

Research investigating increased profitability from merchandising decisions in Appalachia primarily deals with log bucking decisions. Wang et al. (2007) determined that stem dimension, species, bucker experience and defects all impacted the merchandising of individual stems. In this research project, the focus was less on individual stems and more on the feasibility of merchandising low-quality roundwood in Appalachia. We found that delivering roundwood pulpwood to a yard (or sawmill) for the purposes of merchandising sawlogs from the pulpwood was not an economically feasible alternative, at least under the prevailing hardwood market conditions during this research. While there have been general increases in lumber prices compared to those used in this study, they are still not high enough to impact the feasibility of a sort yard system as the one discussed in this paper. In order to at least breakeven, revenues must increase or cost must decrease or a combination of both must occur. Revenue would have to increase 3 percent for hickory, 13 percent for red oak/black oak, 39 percent for black cherry, and 19 percent for white oak/chestnut oak in order to breakeven. Likewise, prices paid for pulp 
would have to decrease significantly in order to break even. Red oak pulp cost would have to decline to $\$ 13.90$, white oak to $\$ 10.40$, and black cherry pulp would not be profitable to sort even if it had zero cost in procurement. In a study of the economics of processing small-diameter red oak logs on a new scragg mill designed for this purpose, Perkins et al. (2008) determined that the net present value and internal rate of return on such an operation were economically feasible at a log cost of $\$ 35 /$ ton. While roundwood costs in this study were only $\$ 25 /$ ton, the additional costs of handling and the burden of non-sawlog roundwood severely impacts the overall revenue found in this operation.

Of the species merchandised in this project, hickory appeared to have the most potential. This is primarily the result of its lack of popularity in the traditional hardwood lumber marketplace. Because of the lack of demand for hardwood dimension products, hickory logs finding their way into other fiber markets contain larger-sized and higher-quality sawlog potential than other species. This is supported by the fact that on average hickory sawlogs merchandised in this study had a larger log diameter, a higher number of clear sides, a higher proportion of butt logs, and a larger log volume. If demand for hickory lumber were to increase and more hickory roundwood diverted to sawlogs as opposed to pulpwood, the average size of potential sawlogs included in pulpwood loads would decrease, as would quality, leading to poorer lumber grade yields and less net revenue. Likewise, it is probably not feasible for such an operation to purchase only hickory roundwood. Sorting burdens would be placed on loggers in such a scenario and would lead to lower amounts of available material.

As expected, the proportion of higher grade lumber is minimal, with the majority of volume being in cant products. However, in the case of black cherry, the log quality was particularly poor, as evidenced by the significant volume of below grade lumber. Over $48 \%$ of the cherry lumber produced during this study was No. $3 \mathrm{~A}$ and below. This was mainly due to a 
large percentage of boards with numerous small knots that severely limited the number and size of clear cuttings. The production of high-grade/high-value lumber drives the profitability of any hardwood log merchandising system; these results reflect a potential hazard in any merchandising operation involving this species. Much of this is due to the size of the cherry roundwood procured for this project, which was smaller than any of the other species sampled. This impacted their profitability in two ways: First, their small size represented increased utilization by the loggers from whom raw materials were purchased from for this project. Increased utilization was due to the loggers merchandising cherry to a smaller size before putting it into the pulpwood markets. Second, because of the smaller diameter logs, the option of leaving the lower grade boards in a cant product (not sawing as much lumber) is limited. During the time of this study, the markets for black cherry lumber were excellent, and many mills were accepting cherry sawlogs with small minimum diameters and no clear sides.

One potential limitation of this study are the lumber yields obtained by our sawmill cooperator. While the operator had $>30$ years experience, all of the merchandised logs were sawn on a circular mill. Because of its increased saw kerf, lumber grade yields may not have been maximized. Band headrigs can increase lumber recovery factors up to 15\% (Wade et al. 1992), which can significantly increase yields on smaller diameter logs.

While hickory had the most potential to be profitable when all facets of merchandising were considered, when considering only merchandised sawlogs, red oaks generated the greatest value per ton. As with species, log profitability was associated with the physical characteristics of the logs including the number of clear sides, scaling diameter and deductions. This indicates that by only merchandising those logs with a greater number of clear sides and a larger scaling diameter as well as a minimum amount of scaling deductions that log profitability will be maximized. All of these factors are known to increase the yield of high grade lumber (Hanks et 
al. 1980), and should be assessed before identifying sawlogs from pulpwood. While it would be expected that merchandising only those logs with the greatest potential for being profitable would increase the overall likelihood of profitability, the iterative revenue analyses did not support this conclusion.

As the value/ton of logs classified as pulpwood increased, the overall revenue of the merchandising operation decreased dramatically. This reflects the merchandising operations need to handle multiple pieces of pulpwood before a higher-value log is found to be merchandised. The greater the degree of handling, the greater the costs incurred (Dramm et al. 2004). A potential scenario leading to greater profitability may be to redirect the merchandising operation down the supply chain to the log landing. Here, small sawlogs can be produced from pulpwoodsized material, and the remaining pulpwood can be sorted and transported directly to a fiberconsuming mill. This would decrease the amount of additional handling and trucking involved in merchandising sawlogs from pulpwood at a sawmill or satellite sort yard.

It is possible, using the data collected in this project, to determine the breakeven prices that a sawmill could offer for the size and quality of logs merchandised in this project. Breakeven sawlog costs can then be used to determine the potential for increased sorting on the log landing, which could be more beneficial to the loggers and sawmill owners. Breakeven sawlog costs were developed based on the grade yield and overrun percentages for the sawlogs merchandised in this study. Break even sawlog cost is determined by solving the log return equation:

$$
\text { Log Return }=\frac{\text { Gain from } \log -\text { sawing cost }- \text { purchase cost }}{\text { sawing cost }+ \text { purchase cost }}
$$

Where: 
Gain from the log: gain calculated on an 1000 board foot (MBF) basis by multiplying the calculated overrun by a 1000 , and then multiplying the resulting total lumber by the lumber grade yield percentages. Prices for each particular lumber grade are then used to determine the total gain from an individual sawlog. The Doyle overrun of the logs used in this study was determined as part of the analysis, and was 42.5 percent, 76.9 percent, 38.4 percent, and 74.4 percent for hickory, red oak, black cherry, and white oak, respectively.

Sawing cost: price to saw logs ( $\$ / M B F)$. A value of $\$ 200 / M B F$ was used in this analyses, Purchase cost: price in $\$ / M B F$ for purchasing sawlogs.

This equation can then be solved for purchase cost for any desired return:

$$
\text { Purchase cost }=-\frac{(\text { Desired return } * \text { sawing cost }- \text { Gain from Log }+ \text { sawing cost })}{(\text { Desired return }+1)}
$$

The breakeven log costs for the red oak species group was the highest at $\$ 321.15 / \mathrm{MBF}$. Both white oak and hickory species had similar breakeven log costs when merchandising variables were ignored and only log profitability was evaluated at $\$ 255.62$ and $\$ 254.34$, respectively. Break even log costs for black cherry were much lower at $\$ 126.01 / \mathrm{MBF}$. At a $10 \%$ profit level, white oak sawlogs would have needed to be purchased at $\$ 200.67 / M B F$, hickory at $\$ 205.31 / M B F$, and red oak at $\$ 259.80$. In order to achieve a $10 \%$ profit level for black cherry logs, they would have had to be purchased at $\$ 89.40 / \mathrm{MBF}$.

Based on the breakeven log costs calculated, it may be feasible for loggers to do more sorting of low grade sawlogs on the landing. While exact prices for gatewood logs paid to loggers are not known, all of the breakeven sawlog costs determined in this project are within reason 
when compared to current stumpage price estimates for the Appalachia region. And, for contract loggers, except for black cherry, the breakeven prices are more than enough to cover the contract logging and trucking rates.

Generally, these small, low grade logs are viewed negatively by traditional hardwood sawmills as evidenced by their well-recognized attempt to discourage their delivery by placing an artificially low delivered price on these logs. It is not uncommon to find instances of pricing ranging down to $\$ 50 / \mathrm{MBF}$, so that mills have significant room to increase prices and maintain a strong level of profit. And, since this breakeven analysis does not include any residue (bark, sawdust, and chips) income, the profit margin is further enhanced.

Numerous bio-energy projects in various stages of development have been announced in or within standard procurement distance of West Virginia's forest resource. Many of these projects rely on obtaining raw-materials at prices that are well below current market conditions. This project was initiated to determine whether the revenue generated from merchandising valuable products from pulpwood was high enough to offset the increased handling costs and lower-value products produced from a sorting operation. While our results were not encouraging, the cost and revenues reported here represent a relatively complex blend of pricing that is dynamic over time. However, as bioenergy markets expand and competition increases with traditional markets, we can expect prices to increase, creating a new set of merchandising options for roundwood. Due to the way the revenue analyses were generated, the formula and conversion ratios presented in this paper can be easily adapted to alternative yield and pricing assumptions, potentially leading to alternative conclusions as market changes occur Likewise, as bioenergy markets expand and log supplies begin to change, sawmills can maintain their supplies through the purchase of lower quality, smaller diameter logs since the results here indicate that they could potentially pay loggers enough to cover their logging and trucking costs plus enough 
profit (or return on stumpage for independent loggers) to ensure that these types of logs are captured on the landing and not sent to the pulp pile as those merchandised in this study.

\section{LITERATURE CITED}

Anonymous, 2007. Directory of wood processing residues in Tennessee 2007. The University of Tennessee Institute of Agriculture. 38pp.

Anonymous, 2009. Woody biomass feedstock yard business development guide. The Federal Wood Biomass Utilization Working Group. From http://www.forestsandrangelands.gov/Woody Biomass/documents/feedstock yard guide. pdf Retrieved Sept. 20, 2010.

Ciolkosz, D.E., C.D. Ray and L. Ma 2010. Modeling fo forest biomass energy potential in Pennsylvania. ASABE Meeting, Pittsburgh, PA, June 20-23, 2010. Paper 1008984: 12.

Dramm, J. R. , G. L. Jackson and J. Wong. 2002. Review of log sort yards. Gen. Tech. Rep. FPLGTR-132. Madison, WI: U.S. Department of Agriculture, Forest Service, Forest Products Laboratory. 39 p.

Dramm, J. R. , R. Govett, T. Bilek, and G.L. Jackson. 2004. Log sort yard economics, planning, and feasibility. Gen. Tech. Rep. FPLGTR-146. Madison, WI: U.S. Department of Agriculture, Forest Service, Forest Products Laboratory. 31 p.

Freund, R. J. and R. C. Littell. 2000. SAS System for Regression, Third Edition. SAS Institute Inc., Cary, NC.

Grushecky, S.T., J. Wang, and D.W. McGill. 2007. Influence of site characteristics and costs of extraction and trucking on logging residue utilization in southern West Virginia. Forest Prod. J. 57(7/8):63-67. 
Grushecky, S.T., D.W. McGill, and R. Bruce Anderson. 2006. Inventory of wood residues in southern West Virginia. North. J. Appl. For. 23(1):47-52

Hardwood Market Report. 2009. Hardwood Market Report, Memphis, TN. December 5, 2009. (www.hmr.com)

Hanks, L. F., G. L. Gammon, R. L. Brisbin, and E.D. Rast. 1980. Hardwood Log Grades and Lumber Grade Yields for Factory Lumber Logs. USDA Forest Service, Northeastern Forest Experiment Station, Broomall, PA. FS Research Paper NE-468. 92pp.

Parhizkar, O. and R.L. Smith. 2008. Application of GIS to estimate the availability of Virginia's biomass residues for bioenergy production. Forest Prod. J. 58(3):71-76.

Perkins, B., R. Smith, and B. Bond. 2008. Case study of the economic feasibility of a red oak small-diameter timber sawmill and pallet-part mill. Wood and Fiber Sci. 40(2):258-270.

Piva, R. J., and G. W. Cook. 2011. West Virginia timber industry: an assessment of timber product output and use, 2007. Resour. Bull. NRS-46. Newtown Square, PA: U.S. Department of Agriculture, Forest Service, Northern Research Station. 58 p.

Massengale, R. 1971. Sawdust, slab and edging weights from mixed oak logs. Southern Lumberman, March 1, 1971:19-20

Rast, E.D., D.L. Sonderman, and G.L. Gammon. 1973. A guide to hardwood log grading (revised). Gen. Tech. Rep. NE-1. Broomall, PA:U.S. Department of Agriculture Forest Service, Northeastern Forest Experiment Station. 34 p.

Spong, B., S. T. Grushecky, and R. Bragonje. 2009. West Virginia Wood By-Products Available and Needed, July 2008. West Virginia University Appalachian Hardwood Center 
Wade, M.W., S.H. Bullard, P.A. Steele, and P.A. Araman. 1992. Estimating hardwood sawmill conversion efficiency based on sawing machine and log characteristics. Forest Prod. J. 42(11/12):21-26.

Wang, J.W. 2007. Hardwood log bucking and loading efficiency in West Virginia. Forest Prod. J. 57(5):84-90.

Wang, J., S. Grushecky, Y. Li and J.F. McNeel. 2007. Hardwood log merchandising and bucking practices in West Virginia. Forest Prod. J. 57(3):71-75

Wu, J., J. Wang and J. F. McNeel 2011. Economic modeling of woody biomass utilization for bioenergy and its application in central Appalachia, USA. Canadian Journal of Forest Research 41: 165-179 


\title{
Chapter 3: A non-hierarchical clustering and ordinal logistic regression approach to developing red oak log grades in the Central Appalachians.
}

\begin{abstract}
Estimating yield based on log characteristics is an essential component in the day to day operations of hardwood sawmills. Yield information can be used to set log prices and determine production costs which are both critical elements in defining hardwood sawmill profitability. This research investigated the combination of cluster analyses and ordinal logistic regression for developing a standard grading table for red oak (Quercus rubra) sawlogs. The multivariate techniques used segregate logs well; however, it is difficult to predict group membership based on log characteristics. A combination of statistical classification and a common sense approach was found to be the best method for developing log grades. The final log grading table may not efficiently classify all logs for all sawmills; however it is the first comprehensive investigation of log grades in over 45 years.
\end{abstract}

\section{INTRODUCTION}

A basic premise associated with hardwood sawlog breakdown is that the amount and quality of lumber produced is highly variable, but has some underlying relationship with log phenotype. While this is common knowledge to those in the industry, the underlying relationship between hardwood logs and lumber have not been investigated for years. One of the main reasons for this is that those in the industry typically don't consider individual profitability of logs. Instead, profitability is done on a gross basis, balancing all species and log characteristics sawn at the mill over an extended time frame (Mayer and Wiedenbeck 2005). While this might work in times where profit margins are large because of limited competition for resources, it will not work as competition and price pressures force sawmills to actively compete for raw materials. In 
competitive log and lumber markets, and with variable costs rising, sawmills can no longer base operational decisions on tradition, but must be supported by a solid knowledge regarding their log resources and mill performance. As these competitive forces continue to converge, small businesses must scrutinize all aspects of their business to ensure the most efficient application of available resources.

In the mid twentieth century, Benson (1941) lamented that understanding log grades was a key to understanding overall sawmill efficiency, especially because of the overall decline in timber quality. Some research has shown that there is a definite increasing trend in the number of low-grade logs (Cumbo et al. 2003). Because of this resource shift, many mills in the Appalachian region have seen increases in the amount of low-grade lumber that they produce (Luppold and Bumgardner 2003). As lumber quality declined, increased focus has been placed on the development of new markets for this output. Regardless of the grade mix they produce, the challenge for sawmills in today's markets is to maintain an effective pricing strategy for lowgrade logs to maintain profitability.

Product yields, log prices, and production costs are critical elements in defining hardwood sawmill profitability. Selection of species, grades, and sawing patterns requires tangible information about the operation. Mills are typically somewhat aware of gross lumber yields among different log size classes; however, most are not aware of the yields they are generating among log grades. By extension, these mills do not have the necessary information to determine which log grades are generating the best financial margins. A traditional barrier to exploring this issue is the non-standard log grading rules within the hardwood industry. The US Forest Service log grading system (Vaughan et al. 1966) has never been widely adopted by the industry. As part of the USDA effort, Hanks et al. (1980) synthesized yield information from approximately 20,000 logs sampled at 75 sawmills. Unfortunately, most of this information has not been used 
by the primary processing industry. There are many reasons for the lack of use, the foremost being its complexity. This system requires users to inspect all four sides or quarters of the log and assess the grade on each side (Hanks et al. 1980). Then the user assigns a grade based on the qualities of the third worst face. Another inherent problem is the inability of the system to separate logs into distinct profitability classes. For a log grading system to be effective, each grade should have a distinct profitability level, where within-group variation is a small as possible.

One of the major obstacles for any sawmill wanting to establish a more effective grading system is the amount of effort it takes to collect the necessary data. Sawmill studies are typically the best means of collecting such information. These methods are not new and have formed the basis for a number of research efforts in the area of log grades and lumber yields (Hanks et al. 1980). However, very few sawmills ever take the time to determine their grade lumber yields without outside impetus. The procedure is time consuming and takes a tremendous amount of labor to complete. Logs must be enumerated, tagged and graded, and then followed through the mill and the resulting lumber must be tallied based on the source log. This typically requires someone recording at the head-rig, the edger, any re-saws, the end trimmer, and on the green chain. After tracking the logs, the resulting data must be entered, analyzed, and then reported. Some have tried to circumvent the added person-time by recording data on only "batches" of logs - hence each board does not have to be traced back to individual logs. However, this process does not give mill owners insight to the decisions that are made on a day to day basis regarding log pricing and sawing - mill performance is lost in the "batch" (Mayer and Wiedenbeck 2005). There are also other deficiencies related to batch studies; which include the loss of yield and value data for the full spectrum of species and log sizes, processing methods, and personnel variation (Mayer and Wiedenbeck 2005). 
The purpose of this research effort is to facilitate the advance of a system for developing standard log grades for Appalachian sawlogs. Some attempts have been made to develop log grades based on lumber yields. Petutschnigg and Katz (2005), used a loglinear model to predict log membership into two grade categories. A model was developed that the authors felt classified the logs well based on target lumber grades. Likewise, Petutschnigg et al. (2009) used a linear modeling technique to associate physical log characteristics with three quality classes. Results from this research suggested that the method could be used to derive grading rules for Norway spruce (Picea abies) and white fir (Abies alba) logs. No recent attempts have been made to establish models that could be used to develop hardwood log grades.

The primary processing industry continues to be under extreme pressure. After going through large consolidations in the late $20^{\text {th }}$ century (Luppold 1995, Luppold 1996), the recent economic downturn has been devastating. In West Virginia, the total number of primary processors declined by sixty percent between 2000 and 2007 (Piva and Cook 2011). The longterm financial resolve of the sawmilling industry will hinge on their ability to accurately determine the value of products that can be produced from a given log before it is sawn. Not only does this help determine what prices can be paid for raw materials, but it can also be used to help estimate what raw material levels are needed to meet market obligations.

\section{METHODS}

\section{Field Data Collection}

To investigate the development of hardwood log grades, data collected through the WVU Appalachian Hardwood Center (AHC) sawmill assistance program was used. The sawmill assistance program began in earnest in early 2005 and has been an ongoing effort since with the mission of helping hardwood sawmills become more profitable. Since inception, the AHC has conducted 45 mill studies at sawmills in the central Appalachians including West Virginia, Virginia, 
North Carolina, Ohio, and Pennsylvania. The primary focus of the assistance program is to help sawmills better understand their production process and especially identifying log characteristics that produce the best results for their mill. To date, over 3700 logs and the resulting 38,000 boards have been tracked through participating sawmills.

Data for the sawmill assistance program are typically collected during a two day on-site study. An attempt is made to sample approximately 100 logs of a single species during each mill visit. The first day each log is graded based on developed methodology. Collected information includes:

1. scaling diameter,

2. log length and trim,

3. surface defects,

4. clear sides,

5. scaling defects,

6. end condition, and

7. weight

Scaling diameter is collected at two points (minimum and maximum) on the scaling end of the log. Log length is measured in feet and trim is recorded in inches. Scaling defects (crook, sweep, interior, and section) are measured and recorded according to methodology outlined in Avery and Burkhart (1994). The number of clear sides is recorded based on the breakdown of the $\log$ into 4 faces and determining the number of faces that are defect free. Surface defects are categorized by size $\left(0-3^{\prime \prime},>3\right.$ to 6 inches and $>6$ inches). End condition was recorded on each log, paying close attention to the presence of ring shake, splits, rot, and double hearts. Weight was recorded for each sawlog using portable load cells and lifting equipment provided by each mill cooperator.

The second day of data collection consists of tracking the enumerated logs through the production process. By positioning field crew members in strategic locations in the cooperating 
mill, every product from each log is numbered. The numbered products are graded by mill employees and the resulting information is recorded by field crew member. Thus the sum of all products from each log is known at the end of the study period. Because time and labor costs are high for these studies, the 100 log sample is used because it represents a reasonable number of logs to characterize and weigh during the first day of the on-site study. Once field data are collected, they are entered electronically into a database system developed for the assistance program.

\section{Analyses}

For this initial attempt at classifying hardwood logs into distinct grades, only red oak (Quercus rubra) and black oak (Quercus velutina) logs were included in analyses. This selection was done for a number of reasons. First, these species comprise approximately $40 \%$ of the logs recorded in the sawmill assistance program. Likewise, red oak and black oak are typically sawn together and lumber prices are the same for both species. While red oak logs of similar size and quality may yield higher grades of lumber than black oak logs, the need for an increased number of samples in the multitude of log type classes necessitates their grouping.

Gross revenue estimates were calculated using the total amount of lumber sawn by grade and the lumber prices obtained from the Hardwood Market Report. Three separate indices of revenue were developed for this paper based on different time periods in order to take into account any relationships with varying lumber prices. The time periods selected for this research included prices from the first week of June 2004, June 2008, and June 2011 Hardwood Market Reports. These distinct periods were chosen because they represented a time when the industry faced high (June 2004), extremely low (June 2008), and current prices for hardwood lumber.

In order to facilitate the segregation of logs into distinct groups based on their characteristics, a multivariate clustering approach was employed. The goal of cluster analysis is 
to find an optimal grouping for which observations are similar and clusters are dissimilar. Using this approach leads to the discovery of natural groupings in the data. Cluster analysis can be both Hierarchical and Nonhierarchial. Hierarchical or agglomerative methods focus on merging observations and previously formed clusters into new clusters by evaluating their proximity (Khattree and Naik 2000). The proximity between clusters is typically measured with a similarity or dissimilarity metric. One of the most commonly used distance metric is the Euclidean or ordinary distance between points:

$$
d\left(X_{i}, Y_{i}\right)=\sqrt{\sum_{i=1}^{n}\left(X_{i}-Y_{i}\right)^{2}}
$$

The Euclidean distance $d\left(X_{i}, Y_{i}\right)$ between points $X_{i}$ and $Y_{i}$ is the distance between the line segment connecting them. The use of the hierarchical methods is typically considered when the researcher has no prior knowledge regarding the final number of clusters. When the ending number of clusters is known, a nonhierarchical approach named K-means clustering can be used. The K-means algorithm finds optimum groupings using a criterion $\mathrm{F}$ that is the sum of the minimum distances between each element and its nearest group center. The function $\mathrm{F}$ takes the form:

$$
F\left(\left\{C_{1}, \ldots, C_{k}\right\}\right)=\sum_{i=1}^{k} \sum_{j=1}^{k}\left\|w_{i j-} \bar{w}_{i j}\right\|
$$

Where $K$ represents the number of clusters, $w_{i j}$ the th observation of the th cluster and $\bar{w}_{i j}$, the centroid of the th cluster (Pena et al. 1999). For all analyses, 5 clusters were selected at the start and the original seed values representing the clusters were picked based on their 
dissimilarity. Each seed is then treated as the cluster center and the clustering routine iteratively investigates the data points and assigns them to the cluster they are closest to. As new points are added to the cluster, the centroid continues to change. This is done until the cluster centroids become stable (SAS 2008).

Once the log grade clusters were defined using the K-means approach, a technique was needed to help identify the membership to the clusters based on log characteristics. A number of multivariate ordination techniques are available, but due to the fact that both categorical and continuous data were used to describe sawlogs, logistic regression was used to develop models for predicting log grade.

Typically, in binary logistic regression, a set of regression coefficients are estimated to predict the probability of the outcome of interest. Instead of ordinary least squares being used to estimate the coefficients, Logistic regression uses the Maximum Likelihood Estimation Technique. In this form, the odds that the dependent variable can be predicted using the independent variables is estimated instead of the true value of the dependent variable. The odds ratio takes the form:

$$
\text { Odds }=\frac{P}{1-P}
$$

Where $P$ is the probability of an event occurring. When we take the log of the odds we get the probability that an event will occur. Thus the model becomes:

$$
\ln \left[\frac{P_{i}}{1-P_{i}}\right]=\alpha+\beta_{1} X_{i 1}+\cdots+\beta_{k} X_{i k}
$$


Where $\mathrm{P}_{\mathrm{i}}$ is the probability that $\mathrm{y}_{\mathrm{i}}=1, \alpha$ is the intercept, and $\beta_{k} X_{i k}$ represents the coefficients and exploratory variables. However, in the log grading problem, we are not dealing with a binary outcome. The goal of this is to predict membership into one of $\mathrm{K}$ groups, which are ordered based on value and or yield. In this case, a variation named ordinal logistic regression is being used to predict membership with multiple groups. The ordinal logistic model is the same model as [4], except that the odds ratio becomes cumulative:

$$
\begin{gathered}
\ln \left[\frac{P_{1}}{1-P_{1}}\right]=\alpha_{1}+\beta_{1} X_{1}+\cdots+\beta_{k} X_{j} \\
\ln \left[\frac{P_{1}+P_{2}}{1-P_{1}-P_{2}}\right]=\alpha_{2}+\beta_{1} X_{1}+\cdots+\beta_{k} X_{j} \\
\ln \left[\frac{P_{1}+P_{2}+, \ldots,+P_{k}}{1-P_{1}-P_{2}-, \ldots,-P_{k}}\right]=\alpha_{2}+\beta_{1} X_{1}+\cdots+\beta_{k} X_{j}
\end{gathered}
$$

Where $\mathrm{k}$ is the number of groups and $\mathrm{j}$ is the number of independent variables. The probability of group membership in the last group is simply one minus the cumulative probabilities of membership in the preceding groups.

For all ordinal logistic models, independent variable selection was accomplished through both a stepwise selection procedure where critical p-values were set to 0.95 and by using the Akaike Information Criteria (AIC) (Bozdogan 1987; Shtatland et al. 2004).

\section{RESULTS AND DISCUSSION}

A total of 1,472 red oak/black oak logs subset from the sawmill program database were used for these analyses. This included 495 black oak and 977 red oak logs. The average scaling 
diameter for logs was 14.3 inches and the average length was 10.4 feet (Table 3.1). On average, the logs included in this study had 2.2 clear sides with a median of 2 .

Table 3.1. Scaling diameter, length, and number of defect-free (clear) sides for red oak logs sawn in the Central Appalachian region. Clear sides reported as mean and (median) due to its categorical scale $(4,3,2,1,0)$.

\begin{tabular}{lrr}
\hline Log Characteristic & Mean & Standard Deviation \\
\hline Scaling Diameter (inches) & 14.2 & 3.3 \\
Length (feet) & 10.5 & 2.5 \\
Clear Sides & $2.2(2)$ & 1.4 \\
\hline
\end{tabular}

When logs are graded, those in the hardwood industry classify them based on their potential value once sawn. Typically, grade designations including Prime, Select, No.1, No.2, and No.3 are used. These classifications can also be found in the research literature (Rappold et al. 2009). The majority of the time, anticipated yields of "select and better" or "common and better" lumber helps to define these log grades. Select and better refers to the National Hardwood Lumber Association (NHLA) grades Select, One Face, and FAS. Common and better refers to the same NHLA grades; however, 1 Common yields are also included. Select and better specifies lumber grades with similar minimums of defect free wood; however, differences exist on how the lumber is graded on each side (face) and for different species (Table 3.2). 
Table 3.2. Grade descriptions and pricing for red oak/black oak lumber. Grade descriptions include minimum board size and clear yield, lumber prices from 2004, 2008, and 2011.

\begin{tabular}{|c|c|c|c|c|c|}
\hline & & & June 2004 & June2008 & June 2011 \\
\hline Lumber Grade & Minimum board size & Basic Clear Yield & Prices (\$/MBF) & & \\
\hline FAS & $6^{\prime \prime}$ by $8^{\prime}$ & $831 / 3 \%$ & 1110 & 850 & 910 \\
\hline FIF & $4^{\prime \prime}$ by $6^{\prime}$ & $831 / 3 \%$ & 1100 & 840 & 900 \\
\hline SEL & $4^{\prime \prime}$ by $6^{\prime}$ & $831 / 3 \%$ & 1090 & 830 & 890 \\
\hline No. 1 Common & $3^{\prime \prime}$ by $4^{\prime}$ & $662 / 3 \%$ & 865 & 615 & 580 \\
\hline No. 2A Common & $3^{\prime \prime}$ by $4^{\prime}$ & $50 \%$ & 635 & 490 & 460 \\
\hline No. 2B Common & $3^{\prime \prime}$ by $4^{\prime}$ & $50 \%$ & 585 & 440 & 410 \\
\hline No. 3A Common & $3^{\prime \prime}$ by $4^{\prime}$ & $331 / 3 \%$ & 575 & 415 & 385 \\
\hline No. 3B Common & $3^{\prime \prime}$ by $4^{\prime}$ & $25 \%$ & 525 & 365 & 335 \\
\hline Cant & \multicolumn{2}{|c|}{ Not sold on NHLA grading basis } & 325 & 325 & 350 \\
\hline Below Grade (BG) & \multicolumn{2}{|c|}{ Industrial product specifications } & 275 & 275 & 300 \\
\hline
\end{tabular}

On average, logs produced $12.4 \%$ FAS and $16.1 \%$ No. 1 Common lumber. Overall, No. 1 Common and better yields averaged $36.9 \%$, and select and better averaged $20.8 \%$ for all logs in the study (Table 3.3). 
Table 3.3. Average lumber grade yields for red oak logs sawn at sawmills in the central Appalachian region.

\begin{tabular}{lrr}
\hline Lumber Grade & \multicolumn{2}{c}{$\begin{array}{c}\text { Standard } \\
\text { deviation }\end{array}$} \\
\hline FAS & 12.4 & 18.6 \\
FIF & 8.2 & 11.1 \\
SEL & 0.2 & 1.4 \\
No. 1 Common & 16.1 & 13.8 \\
No. 2A Common & 14.6 & 12.6 \\
No. 2B Common & 0.3 & 1.9 \\
No. 3A Common & 8.6 & 11.7 \\
No. 3B Common & 4.8 & 9.2 \\
Cant & 32.4 & 6.7 \\
Below Grade (BG) & 2.4 & 24.5 \\
Select and Better & 20.8 & 23.4 \\
No. 1 Common and Better & 36.9 & 27.1 \\
\hline
\end{tabular}

Experience obtained from the sawmill assistance program has indicated that scaling diameter and the number of clear (without defect) log faces help log graders determine log values. While each sawmill has their own approach regarding grade associations, with combinations of scaling diameter and clear sides, the most common or encompassing method synthesized through the sawmill assistance program has 5 grades spread across forty combinations of clear sides and scaling diameter (Table 3.4). While this is in no way a standard for all companies or species, it does represent a common generalization of log grades. Throughout the remainder of this paper, this grading table will be referred to as the "implied grading table". Other references in the literature have included length as another determinant of grade (Rappold 2006), however this was not found to be common in visits conducted as part of data collection for this study. 
Table 3.4. Log grade specifications synthesized during 45 sawmill visits in the Appalachian region. Scaling diameter is rounded to the nearest inch (e.g., $>15.5$ and $<=16.5$ represents the16 inch log class).

$$
\text { Defect Free (Clear) Sides }
$$

Scaling

Diameter

\begin{tabular}{lccccc} 
(inches) & 4 & 3 & 2 & 1 & 0 \\
\hline$>=17$ & Prime & Select & No. 1 & No. 2 & No. 3 \\
16 & Select & Select & No. 1 & No. 2 & No. 3 \\
15 & Select & Select & No. 1 & No. 2 & No. 3 \\
14 & No. 1 & No. 1 & No. 1 & No. 2 & No. 3 \\
13 & No. 1 & No. 1 & No. 1 & No. 2 & No. 3 \\
12 & No. 2 & No. 2 & No. 2 & No. 2 & No. 3 \\
11 & No. 2 & No. 2 & No. 2 & No. 2 & No. 3 \\
$<=10$ & No. 3 & No. 3 & No. 3 & No. 3 & No. 3 \\
\hline
\end{tabular}

The first step in evaluating the construction of a hardwood log grading system is to determine how estimates of gross revenue based on sawn products and select and better lumber yields are segregated in the implied grading table. Results from the 1,472 red oak logs show that estimates of gross revenues based on 2004, 2008, and 2011 lumber prices increase with increasing grade as would be expected (Table 3.5).

Table 3.5. Total gross revenue per sawn board foot for standard lumber grades based on standard grading table grade designations (mean + standard deviation). Revenue based on the first week of June 2004, 2008, and 2011 lumber pricing.

\begin{tabular}{lcrr}
\hline Mill Grade & $\begin{array}{c}\text { Gross Revenue 2004 } \\
(\$ / \mathrm{BF})\end{array}$ & $\begin{array}{c}\text { Gross Revenue 2008 } \\
(\$ / \mathrm{BF})\end{array}$ & $\begin{array}{c}\text { Gross Revenue 2011 } \\
(\$ / \mathrm{BF})\end{array}$ \\
\hline Prime & $0.89(0.10)$ & $0.68(0.08)$ & $0.71(0.09)$ \\
Select & $0.80(0.12)$ & $0.61(0.09)$ & $0.63(0.10)$ \\
No. 1 & $0.71(0.13)$ & $0.55(0.09)$ & $0.55(0.10)$ \\
No. 2 & $0.58(0.12)$ & $0.46(0.08)$ & $0.46(0.08)$ \\
No. 3 & $0.47(0.10)$ & $0.40(0.06)$ & $0.40(0.05)$ \\
\hline
\end{tabular}


The coefficient of variation (CV) averages $17.4,14.7$, and $15.8 \%$ for the 2004,2008 , and 2011 gross revenue estimates, respectively. Although variability is limited in this case, one of the inherent difficulties in using revenues to distinguish log grades is illustrated by the inconsistent differences in gross revenues among the years included in the analyses. For example, gross revenues are consistent for both Prime and Select logs - they decline from 2004 to 2008 and then increase slightly in 2011. However, a gross revenue decline occurs for No.2 graded logs between 2004 and 2008, and then remains constant in 2011. These inconsistencies are related to the relative increases and decreases in prices among various lumber grades. If price changes are not consistent among grades, gross revenues among log grades will not be consistent either. This, along with the fact that pricing is not static, limits the usefulness of gross revenue as a distinguishing variable. The ultimate usefulness of a standard hardwood log grading table would be its relative resilience when faced with price swings in lumber.

Because of the difficulties in using revenues, an alternative discriminating variable would be select and better yields. Because lumber within these grade designations always command the highest pricing and grade sawmills strive to maximize the production of these grades, it would make sense that the combination of these yields would make a better indicator of overall log profitability. Furthermore, the relationship between revenue per board foot sawn and select and better yields is positive and significant $(r=0.97, p<0.0001)$ (Figure 3.1), which suggests that select and better yields could be used as a proxy for gross revenue per board foot sawn. This relationship is consistent for each time period studied. 


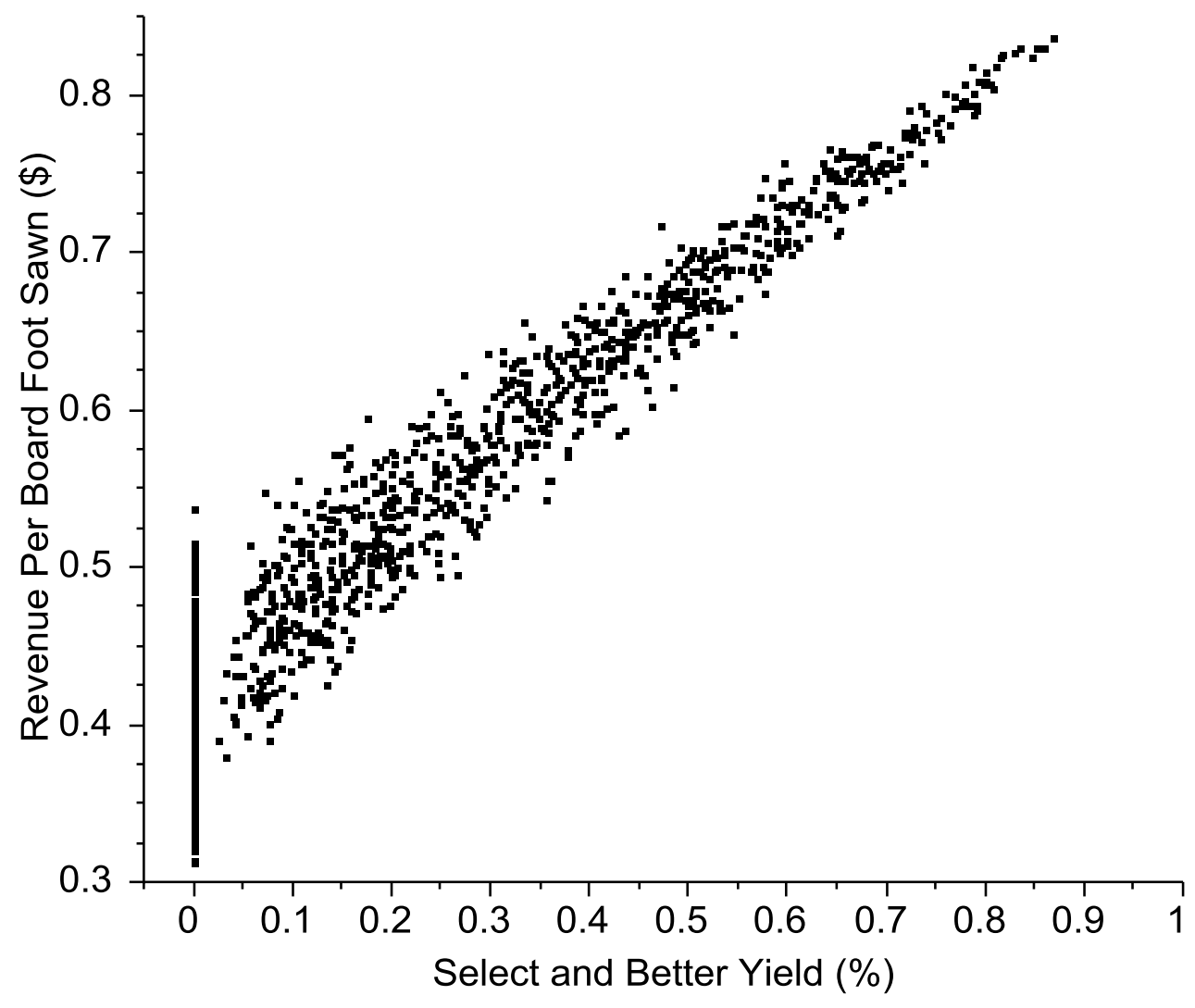

Figure 3.1. Relationship between revenue per board foot sawn (\$) based on June 2011 lumber prices and select and better lumber yields for 1,472 red oak logs sawn in the central Appalachian region.

When the average select and better yields are broken down by the implied log grades, a clear drop occurs in mean yield with decreasing grade (Table 3.6). Taken alone, this appears to support the formation of the implied grading table. However, the standard deviation increases with each decline in log grade, ultimately ending in a CV of over 265 percent for the No. 3 graded logs. This variability limits the attractiveness of this approach because select and better yields are widely variable within a given log grade. 
Table 3.6. Average, standard deviation and coefficient of variation for select and better yields of red oak/black oak sawlogs classified by industry implied log grades.

\begin{tabular}{|c|c|c|c|}
\hline & & Select and Better Yield (\%) & Select and Better Yield(\%) \\
\hline Mill Grade & Select and Better Yield (\%) & Standard Deviation & Coefficient of Variation \\
\hline Prime & 55.4 & 21.2 & 38.2 \\
\hline Select & 40.0 & 21.4 & 53.6 \\
\hline No. 1 & 25.2 & 19.8 & 78.6 \\
\hline No. 2 & 9.5 & 13.8 & 145.7 \\
\hline No. 3 & 2.5 & 6.7 & 267.2 \\
\hline
\end{tabular}

To further understand the problem associated with high variability in select and better yields within a log grade, the prime and select log grades can be plotted (Figure 3.2). In this case, a $50 \%$ density ellipse is imposed over logs that are representative of both the Prime (solid ellipse) and Select (dashed ellipse) log grades. For each of these log grades there is considerable dispersion along the $\mathrm{X}$ axis, which is select and better yields, thus showing the larger amount of variation within a standard mill grade. Likewise, another problem with the implied grading table is represented by the large overlap in density ellipses for the Prime and Select log grades - many of the logs could be classified into both the prime and select mill grade based on their select and better yields. 


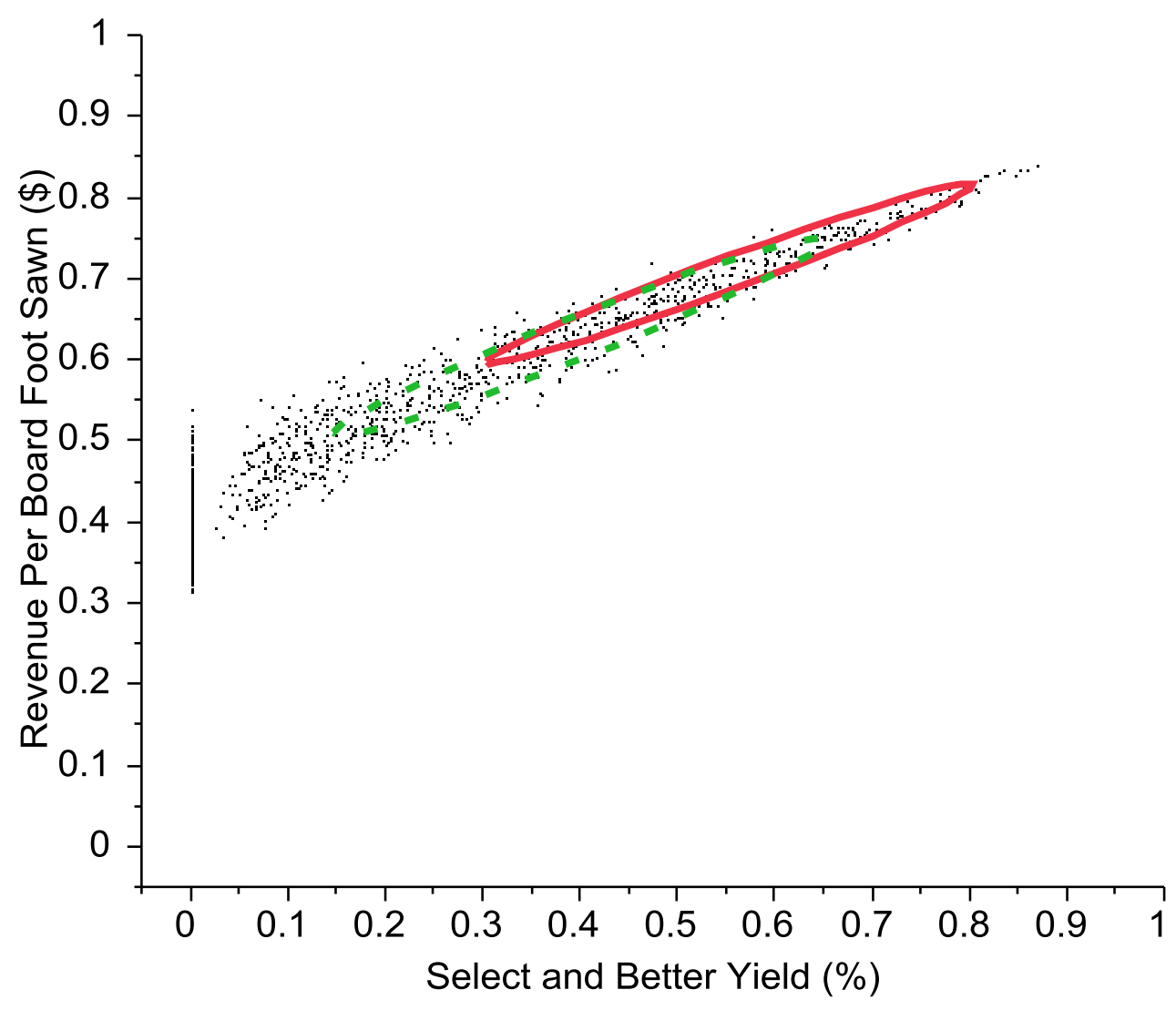

Figure 3.2. Relationship between revenue per board foot sawn (\$) based on June 2011 lumber prices and select and better lumber yields for 1,472 red oak logs sawn in the central Appalachian region. Density ellipses are drawn on $50 \%$ of logs meeting Prime and Select implied grade yields. Prime represented by solid ellipse.

To help reduce the variability in select and better yields among log grades, a K-means clustering approach was used. Because gross revenues and select and better yields were highly correlated, clustering was performed only on select and better yields, in an attempt to reduce its variation within log grades. After 23 separate iterations, 5 new grades were developed based on select and better yields. To be consistent, these grades were also labeled as Prime - No. 3, where the Prime log grade represented logs with the highest select and better yields while No. 3 grade represented those with the lowest. These log grades will be referred to as Type II log grades throughout the remainder of this paper. 
When select and better yield is plotted against revenue per board foot sawn and the Type II log grades are identified, the clearer separation in lumber yields can be observed (Figure 3.3). In this case, logs are partitioned into clear grades based on their select and better yields with little overlap.

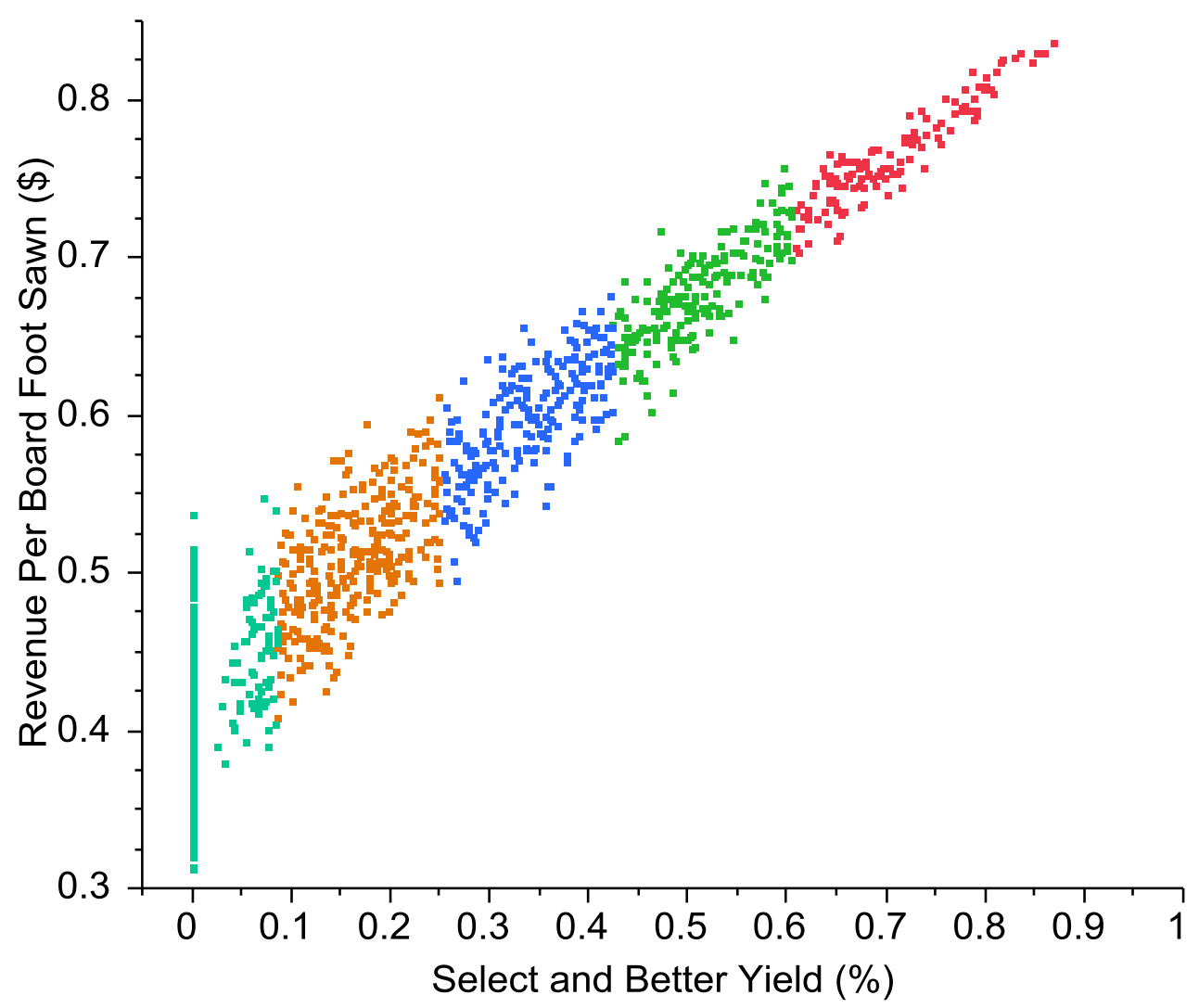

Figure 3.3. Plot of Select and better yield for Red Oak logs by gross revenue per board sawn (\$) using June 2011 lumber prices. Points represent individual red oak logs, point shapes represent $\mathrm{K}$-means clusters for select and better yields.

With the Type II log grades, the overall variability in select and better yields has been reduced using the K-means clustering approach (Table 3.7). The original implied grading table 
had an average CV of $116.7 \%$. The new type II log grades resulting from the $\mathrm{K}$-means clustering approach resulted in a 5-grade average CV of $65.0 \%$, which represents a $44 \%$ reduction.

Table 3.7. Average (standard deviation) select and better yields and gross revenue per board foot of lumber sawn (\$) for red oak log Type II log grades based on K-means clustering.

\begin{tabular}{lrrrr}
\hline \multicolumn{1}{c}{ Log Grade } & $\begin{array}{c}\text { Select and Better } \\
\text { Yields }(\%)\end{array}$ & $\begin{array}{c}\text { Gross Revenue 2004 } \\
(\$ / \mathrm{BF})\end{array}$ & $\begin{array}{c}\text { Gross Revenue 2008 } \\
(\$ / \mathrm{BF})\end{array}$ & $\begin{array}{c}\text { Gross Revenue 2011 } \\
(\$ / \mathrm{BF})\end{array}$ \\
\hline Prime & $70.3(6.6)$ & $0.95(0.04)$ & $0.73(0.03)$ & $.77(0.03)$ \\
Select & $51.2(5.2)$ & $0.85(0.06)$ & $0.66(0.03)$ & $0.68(0.03)$ \\
No. 1 & $33.7(5.1)$ & $0.76(0.07)$ & $0.59(0.04)$ & $0.60(0.04)$ \\
No. 2 & $16.3(4.7)$ & $0.65(0.08)$ & $0.51(0.04)$ & $0.51(0.04)$ \\
No. 3 & $0.9(2.3)$ & $0.50(0.09)$ & $0.41(0.05)$ & $0.41(0.04)$ \\
\hline
\end{tabular}

Moreover, the Type II log grades also reduced the CV for each of the gross revenue estimates for each year. Overall, variability in gross revenue estimates among log grades was reduced by $50 \%$ when using the Type II log grades.

While the Type II log grades do a good job reducing overall variability, there is no means to classify logs into these grades based on external characteristics. To help solve this problem, ordinal logistic regression was used to predict log grade membership based on external log characteristics.

The probability $(\mathrm{P})$ of log grade membership was modeled as follows:

$$
\ln \left[P_{i} /\left(1-P_{i}\right)\right]=\beta_{0}+\beta X_{1}+\cdots+\beta X_{11}
$$

Where: 


$$
\begin{aligned}
& \ln \left[P_{i} /\left(1-P_{i}\right)\right]=\text { the log of the odds ratio for grade membership } \\
& \beta_{0}=\text { intercept terms (one for each grade) } \\
& \beta X_{1}=\text { coefficient and explanatory variable for scaling diameter } \\
& \beta X_{2}=\text { coefficient and explanatory variable for length } \\
& \beta X_{3}=\text { coefficient and explanatory variable for scaling deduction } \\
& \beta X_{4}=\text { coefficient and explanatory variable for clear sides (\# of clear log faces) } \\
& \beta X_{5}=\text { coefficient and explanatory variable for scaling deduction (combination of cull, }
\end{aligned}
$$
internal, sweep, and crook defects)

$$
\begin{aligned}
& \beta X_{6}=\text { coefficient and explanatory variable for total number of defects } \\
& \beta X_{7}=\text { coefficient and explanatory variable for sawlog position in tree (butt or upper) } \\
& \beta X_{8}=\text { coefficient and explanatory variable for presence of splits (split or no split) } \\
& \beta X_{9}=\text { coefficient and explanatory variable for presence of shake (shake or no shake) } \\
& \beta X_{10}=\text { coefficient and explanatory variable for presence of double heart (double heart or }
\end{aligned}
$$
no double heart)

$\beta X_{11}=$ coefficient and explanatory variable for number of clear sides when only large defects are recorded

This form represents the generalized ordinal logistic model. The model intercept and form changes for each group. For example, when modeling for entrance into the Select log grade, the model becomes: 


$$
\ln \left[P_{\text {Prime }}+P_{\text {Select }} /\left(1-P_{\text {Prime }}-P_{\text {Select }}\right)\right]=\beta_{0}+\beta X_{1}+\cdots+\beta X_{11}
$$

The stepwise selection procedure was used to select appropriate variables for model development. For each step, the AIC was recorded. The model that registered both a large decline and at the same time represented the lowest AIC was selected as the best overall model. In this case, the best model for predicting Type II log grades was found to include the number of clear sides, scaling diameter, total scaling deduction, total number of defects, and whether the log was a butt or upper (Table 3.8). Odds ratio estimates also help to show the relationship between Type II log grades and the predictor variables (Table 3.9). For example, in this case, as clear sides increased by 1 unit, the proportional odds of being in the next highest log grade expand 1.9 times.

Table 3.8. Best model developed for predicting log inclusion into Type II log grades using ordinal logistic regression. All parameters were significant at $p<0.00001$.

\begin{tabular}{lrr}
\hline Parameter & \multicolumn{1}{l}{ Estimate } & \multicolumn{1}{c}{ Standard Error } \\
\hline Intercept Prime & -9.3185 & 0.4896 \\
Intercept Select & -7.7733 & 0.4639 \\
Intercept No. 1 & -6.5998 & 0.4479 \\
Intercept No. 2 & -5.1441 & 0.4335 \\
Clear sides & 0.6327 & 0.0917 \\
Scaling Diameter & 0.3266 & 0.0195 \\
Total scaling & -4.18 & 0.9202 \\
deduction & & \\
Total No. Defects & -0.1314 & 0.0318 \\
Butt log (1=yes) & 0.4903 & 0.1224 \\
\hline
\end{tabular}


Table 3.9. Odds ratio estimates for ordinal logistic regression model for predicting log inclusion into Type II log grades. All parameters were significant at $p<0.00001$.

\begin{tabular}{|c|c|c|}
\hline Effect & Point Estimate & 95\% Wald Confidence Limit \\
\hline Clear sides & 1.883 & $1.573-2.253$ \\
\hline Scaling Diameter & 1.386 & $1.334-1.440$ \\
\hline Total scaling deduction & 0.015 & $0.003-0.092$ \\
\hline Total No. Defects & 0.877 & $0.824-0.933$ \\
\hline Butt log (1=yes) & 1.633 & $1.285-2.075$ \\
\hline
\end{tabular}

While the final model is significant, the actual classification results must be examined. For each log in the dataset, the ordinal logistic model was used to develop the probability that each log belonged to each Type II log grade. For example, using the parameters from Table 3.8, the model for estimating the probability of a logs membership in the "Prime" group becomes:

Prob.Prime $=\frac{e^{(-9.3185+0.6327 * \text { No.Clr.Sides }+0.3266 * \text { Scal.D.-4.18*Tot.Scal.Ded. }-0.1314 * \text { Tot.No.Def. }+0.4903 * \text { Butt })}}{1+e^{(-9.3185+0.6327 * \text { No.Clr.Sides }+0.3266 * \text { Scal.D. }-4.18 * \text { Tot.Scal.Ded. }-0.1314 * \text { Tot.No.Def. }+0.4903 * \text { Butt })}}$

The equation parameters are then changed for each subsequent group using those presented in Table 3.8. For the No. 3 log grade, the probability is simply:

Prob. No. $3=1-\Sigma($ Prob. Prime, Prob. Select, Prob. No. 1,Prob. No. 2) 
Probabilities were calculated for each observation using the Type II logistic model. For each log, the predicted log grade was chosen based on the grade with the highest probability. The predicted Type II log grade was cross-classified with the Type II log grade determined through the cluster analyses. A total of 815 out of the 1,472 were correctly classified (55.4\% correct classification rate). This low classification rate suggests that this model is not useful for predicting membership in the Type II log grades. It should be also noted that several other multivariate analysis techniques were attempted including discriminant and non-parametric discriminant analyses, and artificial neural network analyses. All techniques resulted in similar classification results.

While the Type II log grades reduced variation when compared to the original implied log grades, a suitable model for predicting group membership was not found. Another potential means of classifying logs into the Type II log grades is to use both the ordinal logistic model [8] and the original clear sides and scaling diameter approach (Table 3.3). Using the probability models developed for Type II log grades, an algorithm was developed to select the log grades based on cell frequencies, which takes the form:

$$
\text { Cell Classification }=\operatorname{MAX}(\text { Freq }(\text { Prime, Select, No.1,No. 2, No.3) }
$$

To perform this classification, each log was classified by its scaling diameter and number of clear sides. For each of the 40 cells in the grading matrix, the frequency of log grade classifications for each was calculated. Then, the log grade with the greatest frequency distribution was assigned to that cell. This produced a new log grading table - Type III Log Grades (Table 3.10). 
Table 3.10. Type III log grading table developed using ordinal logistic model and predicted cell frequencies

Defect Free (Clear) Sides

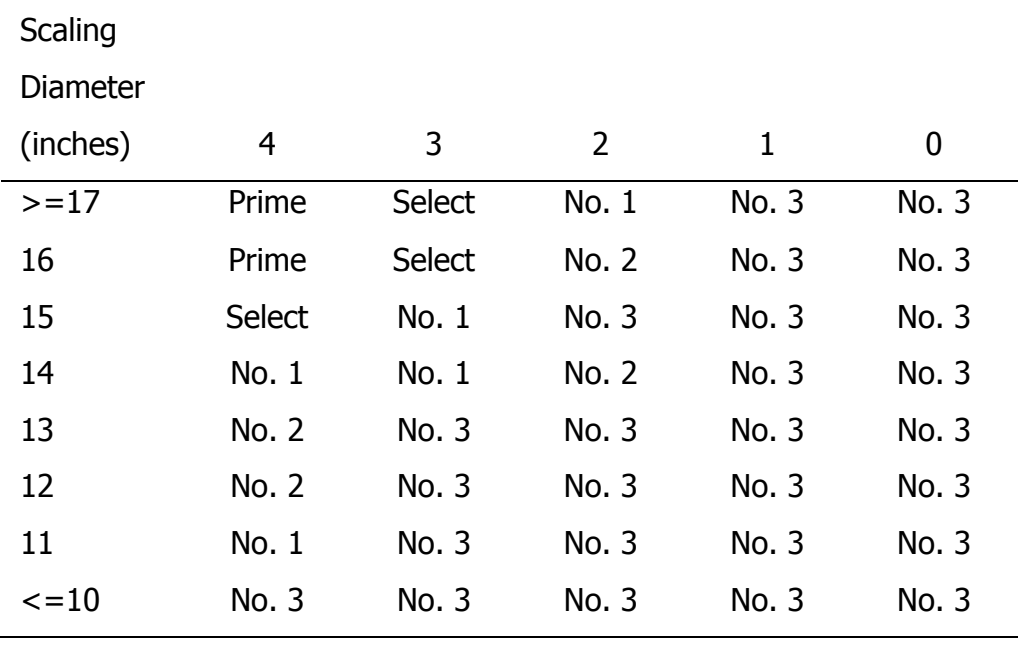

One minor inconsistency with this table is that an unrealistic grade shifts occur when scaling diameter $=11$ and clear sides $=4$ (No. 1) as well as when scaling diameter $=15$ and clears sides $=2$ (No. 3). These are likely due to the inherent variability in lumber yields from red oak/black oak sawlogs. If the log grades in these cells are switched to appropriate values (No. 2 in 11 inches and 4 clear sides and No. 2 in 15 inches and 2 clear sides), the overall variability in the new grading table can be investigated. As would be expected, the overall CV in select and better yields is higher than that found in the Type II log grades ( $83 \%$ versus $65 \%$ ), however, it is still considerably lower than that found in the implied log grading table (117\%) (Table 3.11). 
Table 3.11. Average (standard deviation) select and better yields and gross revenue per board foot of lumber sawn for red oak log Type III log grades based on ordinal logistic model and frequency algorithm.

\begin{tabular}{lrrrr}
\hline \multicolumn{1}{c}{ Mill Grade } & $\begin{array}{c}\text { Select and Better } \\
\text { Yields }(\%)\end{array}$ & $\begin{array}{c}\text { Gross Revenue 2004 } \\
(\$ / \mathrm{BF})\end{array}$ & $\begin{array}{c}\text { Gross Revenue 2008 } \\
(\$ / \mathrm{BF})\end{array}$ & $\begin{array}{c}\text { Gross Revenue 2011 } \\
(\$ / \mathrm{BF})\end{array}$ \\
\hline Prime & $53.5(21.4)$ & $0.88(0.11)$ & $0.67(0.08)$ & $0.70(0.10)$ \\
Select & $40.9(21.3)$ & $0.80(0.12)$ & $0.62(0.09)$ & $0.63(0.10)$ \\
No. 1 & $31.8(19.5)$ & $0.75(0.12)$ & $0.58(0.09)$ & $0.59(0.10)$ \\
No. 2 & $22.5(18.5)$ & $0.68(0.13)$ & $0.53(0.09)$ & $0.54(0.10)$ \\
No. 3 & $6.7(12.1)$ & $0.54(0.13)$ & $0.44(0.08)$ & $0.44(0.08)$ \\
\hline
\end{tabular}

Variation in revenue among groups has increased over the Type II log grades, however, it is approximately the same as the original implied log grades. It should be noted that the average select and better yields for each of the log grades using the Type III system are considerably smaller than those found with the Type II system and more closely follow the industry implied grading system.

To further investigate the usefulness of the multivariate clustering technique on developing red oak log grades, an approach where clusters are delineated based on multiple characteristics was performed. This can be done using a number of variables; however, the more variables used to develop clusters, the more difficult it is to accomplish a variation reduction in a single variable. Thus, the more variables added, the more unlikely a direct reduction in group homogeneity in select and better yields would be observed.

To help reduce this problem in developing new clusters, only the following variables were used in addition to select and better yields; number of clear sides, scaling diameter, log length and the resulting combinations. Clustering with clear sides had the smallest average centroid distance for each of the 5 groups, followed by cluster with number of clear sides and scaling diameter and then number of clear sides, scaling diameter and length (Table 3.12). 
Table 3.12. Individual results from multiple attempts at multivariate K-means clustering for the development of red oak/black oak log grades.

\begin{tabular}{lccc}
\multicolumn{1}{c}{ Cluster Approach } & \multicolumn{2}{c}{$\begin{array}{c}\text { Average CV of Select and } \\
\text { Better Yield (\%) }\end{array}$} \\
\hline $\begin{array}{l}\text { No. Clear Sides and Select and Better Yields } \\
\text { No. Clear Sides, Scaling Diameter and Select and }\end{array}$ & 1.23 & 90.2 \\
$\begin{array}{l}\text { Better Yields } \\
\text { No. Clear Sides, Scaling Diameter, Length and Select } \\
\text { and Better Yields }\end{array}$ & 2.45 & 111.9 \\
\hline
\end{tabular}

Likewise, clustering with the number of clear sides and select and better yields had the least amount of variability in select and better yields within groups. The across group average CV for clustering with the number of clear sides was $90.0 \%$, followed by $111.9 \%$ for the number of clear sides, scaling diameter and select and better yields, and $114.6 \%$ when all three were used in the clustering algorithm. While all are less than the CV found for select and better yields by standard mill grades (116.7\%), only the cluster with the number of clear sides and select and better yields is considerably lower, representing a $23 \%$ decline in variation across all groups (Table 3.13). This log grade result will be considered log grade Type IV throughout the remainder of this paper.

Table 3.13. Average (standard deviation) number of clear sides and select and better yields for red oak/black oak log Type IV grades based on K-means clustering using number of clear sides and select and better yields.

\begin{tabular}{|c|c|c|}
\hline Mill Grade & $\begin{array}{c}\text { Number of Clear Sides } \\
\text { (Stand. Dev.) }\end{array}$ & $\begin{array}{c}\text { Select and Better Yield (\%) } \\
\text { (Stand. Dev.) }\end{array}$ \\
\hline Prime & $3.6(0.6)$ & $61.4(10.3)$ \\
\hline Select & $1.7(0.5)$ & 31.7 (11.9) \\
\hline No. 1 & $3.5(0.5)$ & $29.6(9.9)$ \\
\hline No. 2 & $2.6(0.04)$ & $4.1(5.5)$ \\
\hline No. 3 & $0.5(0.02)$ & $2.3(5.3)$ \\
\hline
\end{tabular}


While there was a considerable reduction in variation in select and better yields, and the Type IV clustering approach provides for a relatively distinct separation when viewed graphically (Figure 3.4), the fact that several of the average select and better yields are similar for multiple log grades (Select and No. 1) is troublesome. In order for this technique to help achieve good discrimination, select and better yields should be more distinct for each of the categories.

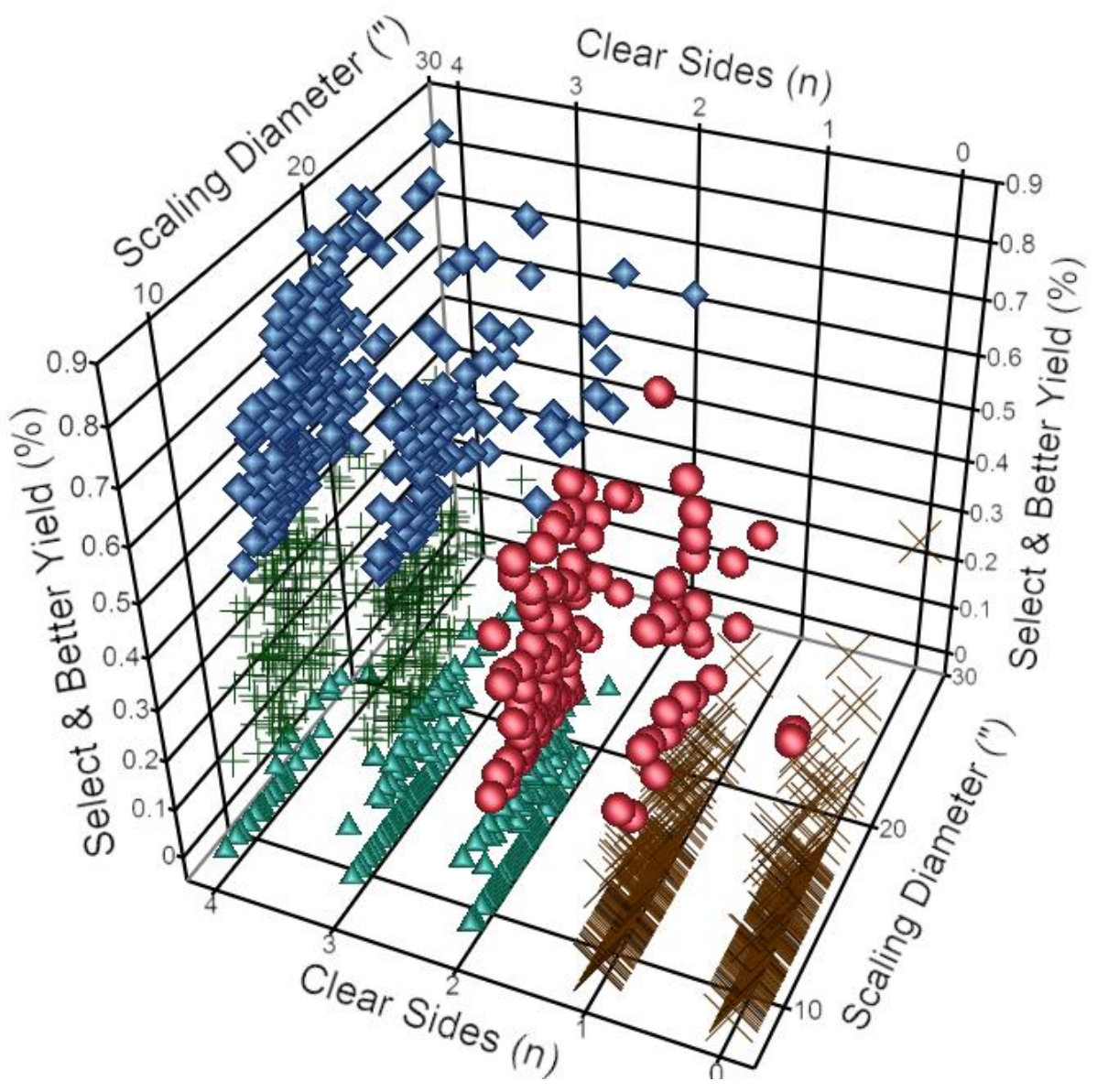

Figure 3.4. Three dimensional scatterplot detailing results of K-means clustering of red oak logs. Results show Type IV log grade clusters using select and better yields (\%), number of clear sides and scaling diameter (inches) as response variables. Points represent logs, markers represent clusters.

Although the lack of group separation is noted, ordinal logistic regression was used to develop a model to predict group classification based on log characteristics. The same starting 
model used in prior analyses [6] \& [7] was used in this problem. The stepwise selection procedure and AIC were used to select the best model. The final model for predicting Type IV log grades was found to include the number of clear sides, scaling diameter, and total number of defects (Table 3.14). As in the previous model, the number of clear sides and scaling diameter were the most related to the inclusion in a specific Type IV log grade (Table 3.15). As clear sides increased by 1 unit, the proportional odds of being in the next highest log grade expand 2.6 times, likewise as the scaling diameter increased by 1 unit, the proportional odds increased by 1.3 times.

Table 3.14. Best model developed for predicting log inclusion into Type IV log grades using ordinal logistic regression. All parameters were significant at $p<0.00001$.

\begin{tabular}{|c|c|c|}
\hline Parameter & Estimate & Standard Error \\
\hline Intercept Prime & -8.2341 & 0.4990 \\
\hline Intercept Select & -7.5279 & 0.4894 \\
\hline Intercept No. 1 & -6.0626 & 0.4694 \\
\hline Intercept No. 2 & -3.5049 & 0.4493 \\
\hline No. Clear sides & 0.986 & 0.1001 \\
\hline Scaling Diameter & 0.2825 & 0.0197 \\
\hline Total No. Defects & -0.2856 & 0.0389 \\
\hline
\end{tabular}

Table 3.15. Odds ratio estimates for ordinal logistic regression model for predicting log inclusion into Type IV log grades. All parameters were significant at $p<0.00001$.

\begin{tabular}{lrr}
\hline \multicolumn{1}{c}{ Effect } & Point Estimate & 95\% Wald Confidence Limit \\
\hline No. Clear sides & 2.680 & $2.203-3.261$ \\
Scaling Diameter (inches) & 1.326 & $1.276-1.379$ \\
Total No. Defects & 0.752 & $0.696-0.811$ \\
\hline
\end{tabular}

Again, the equations [3] and [4] were used to develop the probabilities for each logs inclusion in the Type IV log grades. The predicted Type IV log grade was cross-classified with the Type IV log grade determined through the cluster analyses. A total of 967 out of the 1,472 were 
correctly classified $(65.7 \%$ correct classification rate). While this is a much better classification rate than the previous model, it is still low. This coupled with the fact that the select and better yields are very similar for several of the Type IV log grades, suggests that more analysis is needed.

In an attempt to improve the overall Type IV grading table, a fifth grading table was developed using the ordinal logistic model and cell frequency algorithm (equations [8], [9], and [10]). This grading table will be referred to as the Type $V$ approach throughout the remainder of this paper (Table 3.16).

Table 3.16. Type $\mathrm{V}$ log grading table developed using ordinal logistic model and predicted cell frequencies Defect Free (Clear) Sides

Scaling

Diameter

\begin{tabular}{cccccc} 
(inches) & 4 & 3 & 2 & 1 & 0 \\
\hline$>=17$ & Prime & Prime & Select & No. 3 & No. 3
\end{tabular}

16 Prime No. 1 Select No. 3 No. 3

15 Prime No. 1 No. 2 No. $3 \quad$ No. 3

14 No. $1 \quad$ No. $1 \quad$ No. $2 \quad$ No. $3 \quad$ No. 3

13 No. $1 \quad$ No. $1 \quad$ No. $2 \quad$ No. $3 \quad$ No. 3

12 No. $1 \quad$ No. $2 \quad$ No. $2 \quad$ No. $3 \quad$ No. 3

11 No. $1 \quad$ No. $2 \quad$ No. $2 \quad$ No. $3 \quad$ No. 3

$\begin{array}{llllll}<=10 & \text { No. } 2 & \text { No. } 2 & \text { No. } 2 & \text { No. } 3 & \text { No. } 3\end{array}$

One hierarchical ordering problem is noted in this table at scaling diameter=16 and clear sides $=2$ which was designated a Select. Based on an applied thought process, this cell should be switched to a No. 1 log grade. Again, these problems are associated with the inherent variability in lumber yields from red oak/black oak sawlogs. If the log grade in this cell is switched to a more logical value (No.1 in 16 inches and 2 clear sides), the overall variability in the new grading table can be investigated. The overall CV in select and better yields was higher than that found in 
the Type IV log grades (107.1\% versus $90 \%$ ), and only marginally lower than that found in the Implied log grading table (117\%) (Table 3.17).

Table 3.17. Average (standard deviation) select and better yields and gross revenue per board foot of lumber sawn for red oak log Type IV log grades based on ordinal logistic model and frequency algorithm.

\begin{tabular}{lrrrr}
\hline Mill Grade & $\begin{array}{c}\text { Select and Better } \\
\text { Yields }(\%)\end{array}$ & $\begin{array}{c}\text { Gross Revenue 2004 } \\
(\$ / B F)\end{array}$ & $\begin{array}{c}\text { Gross Revenue 2008 } \\
(\$ / B F)\end{array}$ & $\begin{array}{c}\text { Gross Revenue 2011 } \\
(\$ / B F)\end{array}$ \\
\hline Prime & $48.3(22.1)$ & $0.85(0.12)$ & $0.65(0.09)$ & $0.67(0.10)$ \\
Select & $40.9(21.7)$ & $0.78(0.13)$ & $0.60(0.09)$ & $0.61(0.11)$ \\
No. 1 & $31.8(19.4)$ & $0.73(0.13)$ & $0.56(0.09)$ & $0.57(0.10)$ \\
No. 2 & $22.5(12.9)$ & $0.57(0.12)$ & $0.46(0.07)$ & $0.46(0.08)$ \\
No. 3 & $6.7(9.9)$ & $0.51(0.12)$ & $0.42(0.07)$ & $0.42(0.08)$ \\
\hline
\end{tabular}

Variation in revenue among groups for the Type $\mathrm{V}$ log grades has increased over the Type IV log grades from 11.5 to an average of $16.7 \%$, however, it is approximately the same as the original implied log grades. The separation in select and better yields is much better in the Type V log table than the Type IV and more closely resembles the implied standard log grade table. One main criticism of the Type $V$ log table from a practical viewpoint is the limited number of "Select" grade designations. With only 2 cells out of the 40 cell matrix meeting this designation, it is likely not appropriate to introduce this grading table.

At this point, a total of five different log grading tables were evaluated for their ability to separate red oak logs into distinct select and better lumber yield categories. While most of these tables had lower variability within log grades than the implied standard, they all contained problems. Gross revenue estimates based on 2011 lumber prices had the least amount of variability within log grades for each log grade type developed (Table 3.18). 
Table 3.18. Comparison of five different approaches for developing red oak log grading table. Includes key parameters including the coefficient of variation (CV) for gross revenue per board foot sawn (\$) based on June 2011 lumber prices and the $\mathrm{CV}$ for select and better lumber yields.

\begin{tabular}{|c|c|c|c|c|c|}
\hline Type & Approach & $\begin{array}{l}\text { Gross Rev. } \\
\text { CV }\end{array}$ & Sel. \& Btr. CV & Weakness & Strength \\
\hline Type I & $\begin{array}{l}\text { Implied Standard Log } \\
\text { Grade Table }\end{array}$ & $15.8 \%$ & $116.7 \%$ & $\begin{array}{l}\text { Large Sel. \& Btr. } \\
\text { Variability }\end{array}$ & Being used \\
\hline Type II & $\begin{array}{l}\text { Sel. \& Btr. Cluster alone } \\
\text { - ordination to pick } \\
\text { membership }\end{array}$ & $6.5 \%$ & $65.03 \%$ & $\begin{array}{l}\text { Hard to predict } \\
\text { group } \\
\text { membership - } \\
55 \% \text { class. rate }\end{array}$ & $\begin{array}{l}\text { Homogeneity in } \\
\text { Revenue and Sel. } \\
\& \text { Btr. across } \\
\text { grades }\end{array}$ \\
\hline Type III & $\begin{array}{l}\text { Grade table built on } \\
\text { Freq. Algorithm in Sel. \& } \\
\text { Btr. Cluster }\end{array}$ & $16.4 \%$ & $83.3 \%$ & $\begin{array}{l}\text { Raised Sel. \& Btr. } \\
\text { CV 1.2x over Type } \\
\text { II, and Gross Rev. } \\
\text { 2.6x over Type II }\end{array}$ & $\begin{array}{l}\text { Equivalent Rev. CV } \\
\text { as Type I, but } \\
\text { much better Sel. \& } \\
\text { Btr. CV }\end{array}$ \\
\hline Type IV & $\begin{array}{l}\text { Sel. \& Btr. and No. Clear } \\
\text { Sides Cluster ordination } \\
\text { to pick membership }\end{array}$ & $10.2 \%$ & $90.2 \%$ & $\begin{array}{l}\text { Better prediction } \\
\text { than Type II, but } \\
\text { still hard to predict } \\
\text { membership - } \\
66 \% \text { class. rate }\end{array}$ & $\begin{array}{l}\text { Homogeneity in } \\
\text { Rev. and Sel. \& } \\
\text { Btr. across grades }\end{array}$ \\
\hline Type V & $\begin{array}{l}\text { Grade table built on } \\
\text { Freq. Algorithm in Sel. \& } \\
\text { Btr. And No.Clear Sides } \\
\text { Cluster }\end{array}$ & $16.5 \%$ & $107.1 \%$ & $\begin{array}{l}\text { Second highest } \\
\text { Rev. and Sel. \& } \\
\text { Btr. CV }\end{array}$ & $\begin{array}{l}\text { Slightly more } \\
\text { homogeneous Rev. } \\
\text { than Type I }\end{array}$ \\
\hline
\end{tabular}

Of the log tables compared, the Type II table was the most favorable in terms of revenue CV and select and better yield CV. However, use of this method is problematic. With the data that were collected and models developed only $55 \%$ of the logs classified could be placed in the appropriate Type II grade designation. The next best model in terms of gross revenue per sawn board foot and select and better yields is the Type III table, which uses the Type II table as its foundation. While this table has the most desirable analytical qualities of all those introduced, it may not be the most appropriate in a real world setting. On further investigation of the smoothed table ( $11^{\prime \prime}$ scaling diameter and 4 clear sides, $15^{\prime \prime}$ scaling diameter and 2 clear sides), it 
can be seen that out of the 40 cells in the matrix, 25 (62.5\%) of them of them are in the lowest grade category, No. 3 (Table 3.19). In the implied standard table, only $30 \%$ of the cells are in the lowest grade designation. In most situations, it would be highly unlikely that a log buyer or mill owner would feel comfortable assigning the lowest log grade to this many clear side and scaling diameter combinations.

Table 3.19. Type III grading table with two cells modified (shaded). Original Type III table developed using ordinal logistic model and predicted cell frequencies algorithm. Cells that were modified are shaded.

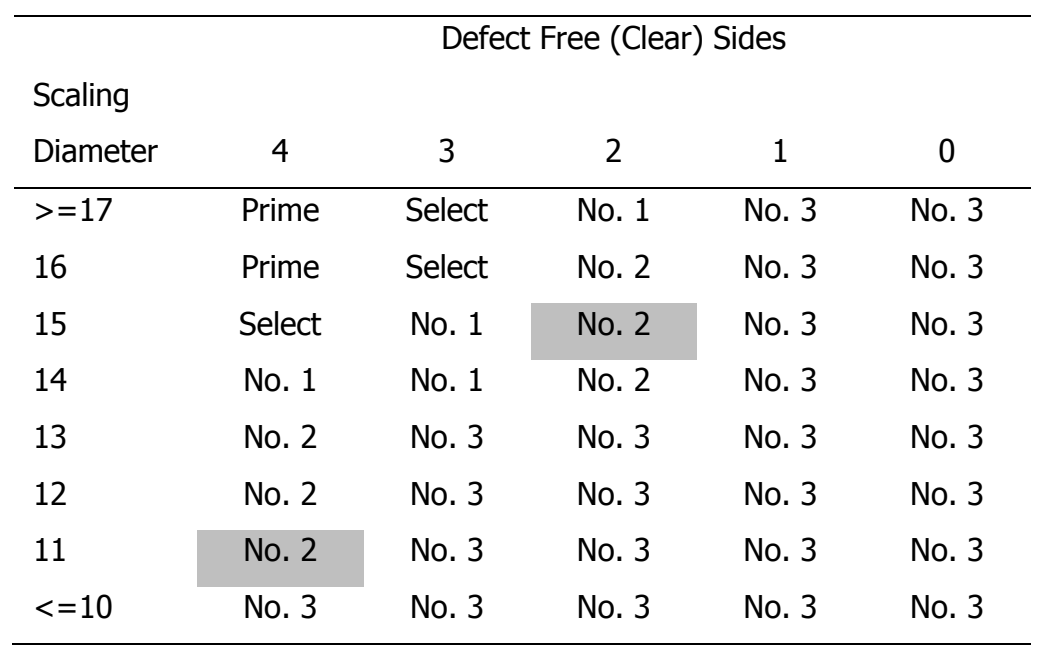

One approach that could be taken is to modify the Type III table based purely on select and better yields within the individual cells. This would help redefine cells where unrealistic classifications were made. A view of select and better yields of the logs used in these analyses clearly shows discrepancies in yield in the lower grade classes. Likewise, some discrepancies are also obvious in other areas of the table, for instance the decline in grade from 14 inches and 4 clear sides to 13 inches and 4 clear sides even though the yields remain the same (Table 3.20). While designating grades based on this approach leaves out the influence of heterogeneity among cells, cell sample sizes in the majority of this table are $\geq 30$, where the mean and variance of a 
population tend to stabilize. In previous discussions of this topic Mayer and Wiedenbeck (2005) recommended working with at least 50 logs per grade, and adjusting this upward based on the influence of additional logs on the $\mathrm{R}^{2}$ statistic.

Table 3.20. Standard grading matrix with select and better yields and number of logs in parenthesis for red oak logs sawn in the central Appalachian region.

Defect Free (Clear) Sides

Scaling

Diameter

\begin{tabular}{lccccc} 
(inches) & 4 & 3 & 2 & 1 & 0 \\
\hline$>=17$ & $0.56(101)$ & $0.41(80)$ & $0.37(40)$ & $0.16(31)$ & $0.09(13)$ \\
16 & $0.49(54)$ & $0.37(53)$ & $0.22(37)$ & $0.14(18)$ & $0.04(20)$ \\
15 & $0.43(19)$ & $0.43(32)$ & $0.30(29)$ & $0.16(56)$ & $0.10(47)$ \\
14 & $0.34(49)$ & $0.25(42)$ & $0.15(33)$ & $0.06(26)$ & $0.02(24)$ \\
13 & $0.33(44)$ & $0.22(58)$ & $0.10(45)$ & $0.05(30)$ & $0.08(37)$ \\
12 & $0.20(27)$ & $0.1(26)$ & $0.08(35)$ & $0.03(38)$ & $0.02(34)$ \\
11 & $0.18(13)$ & $0.12(24)$ & $0.07(20)$ & $0.02(42)$ & $0.00(41)$ \\
$<=10$ & $0.09(10)$ & $0.13(16)$ & $0.06(28)$ & $0.04(48)$ & $0.01(52)$ \\
\hline
\end{tabular}

In order to evaluate the Type III table that has been hybridized based on select and better yields (Table 3.21), the CV for yields and revenues were calculated so that comparisons could be made to previous tables. 
Table 3.21. Hybrid Type III grading table for red oak sawlogs based on Type III table and select and better yield similarities.

\begin{tabular}{|c|c|c|c|c|c|}
\hline Scaling & \multicolumn{5}{|c|}{ Defect Free (Clear) Sides } \\
\hline $\begin{array}{l}\text { Diameter } \\
\text { (inches) }\end{array}$ & 4 & 3 & 2 & 1 & 0 \\
\hline$>=17$ & Prime & Select & No. 1 & No. 2 & No. 3 \\
\hline 16 & Select & Select & No. 1 & No. 2 & No. 3 \\
\hline 15 & Select & Select & No. 1 & No. 2 & No. 3 \\
\hline 14 & No. 1 & No. 1 & No. 2 & No. 3 & No. 3 \\
\hline 13 & No. 1 & No. 2 & No. 2 & No. 3 & No. 3 \\
\hline 12 & No. 2 & No. 2 & No. 3 & No. 3 & No. 3 \\
\hline 11 & No. 2 & No. 2 & No. 3 & No. 3 & No. 3 \\
\hline$<=10$ & No. 3 & No. 3 & No. 3 & No. 3 & No. 3 \\
\hline
\end{tabular}

The hybrid Type III table has identical classifications as the original Type III table for 70.7 $\%$ of the 1,472 red oak logs used in the analyses. The majority (54.2\%) of the differences in log classifications occurred when the Type III table had a log as a No. 3, and the hybrid table had the $\log$ as a No. 2. This reclassification helped to alleviate one of the main issues with the original Type III grade table. Although the CV associated with select and better yields increased from $83.3 \%$ in the original Type III grade table to $100.1 \%$ with the hybrid table, it was still $14.2 \%$ lower than the industry implied grading table (Table 3.22). The average CV for all revenue calculations was relatively the same for both the Type III and Type III hybrid tables. 
Table 3.22. Average (standard deviation) select and better yields and gross revenue per board foot of lumber sawn for red oak log Type III hybrid log grades based on Type III table and select and better yield similarities.

\begin{tabular}{lcrrr}
\hline \multicolumn{1}{c}{ Mill Grade } & $\begin{array}{c}\text { Select and Better } \\
\text { Yields }(\%)\end{array}$ & $\begin{array}{c}\text { Gross Revenue 2004 } \\
(\$ / \mathrm{BF})\end{array}$ & $\begin{array}{c}\text { Gross Revenue 2008 } \\
(\$ / \mathrm{BF})\end{array}$ & $\begin{array}{c}\text { Gross Revenue 2011 } \\
(\$ / \mathrm{BF})\end{array}$ \\
\hline Prime & $55.4(21.1)$ & $0.89(0.10)$ & $0.68(0.08)$ & $0.71(0.09)$ \\
Select & $40.0(21.4)$ & $0.80(0.12)$ & $0.61(0.09)$ & $0.63(0.10)$ \\
No. 1 & $29.6(20.2)$ & $0.73(0.13)$ & $0.57(0.09)$ & $0.58(0.10)$ \\
No. 2 & $15.2(15.9)$ & $0.64(0.13)$ & $0.50(0.08)$ & $0.50(0.09)$ \\
No. 3 & $0.03(8.1)$ & $0.49(0.10)$ & $0.41(0.06)$ & $0.41(0.06)$ \\
\hline
\end{tabular}

A total of six different log grading tables for red oak sawn in the Appalachian region were presented in this analysis. Each table was evaluated and compared to other tables based on gross revenues per board foot sawn and select and better lumber yields. Of all the grading strategies proposed, the Type III table has the most desirable analytical qualities, however as discussed, it may not be the most appropriate in a real world setting. A new log grading table was developed based on the Type III table which further segregated log grades by select and better yields - using a more practical approach. While this grading table may not be appropriate for all sawmills and all red oak/black oak sawlogs, it is an important first step in a consistent methodology and protocol for developing standard log grades for the hardwood industry. 


\section{LITERATURE CITED}

Avery, T. E., and H.E. Burkhart. 1994. Forest Measurements., 4th ed. McGraw-Hill, New York, $408 \mathrm{pp}$.

Benson, A.O. 1941. Something new in hardwood log grades. Journal of Forestry 39(1):13-15

Bozdogan, H. 1987. Model selection and Akaike's Information Criterion (AIC): The general theory and its analytical extensions. Psychometrika 52: 345-370

Cumbo, D. , R. Smith, and P. Araman. 2003. Low-grade hardwood lumber production, markets, and issues. Forest Prod. J. 53(9):17-24

Flom, P.L. 2010. Multinomial and ordinal logistic regression using PROC LOGISTIC. Proceedings of the $23^{\mathrm{RD}}$ Annual NorthEast SAS Users Group Conference. November 2010, Baltimore Maryland. Online: http://www.nesug.org/Proceedings/nesug10/sa/sa03.pdf

Hanks, L. F., G. L. Gammon, R. L. Brisbin, and E.D. Rast. 1980. Hardwood Log Grades and Lumber Grade Yields for Factory Lumber Logs. USDA Forest Service, Northeastern Forest Experiment Station, Broomall, PA. FS Research Paper NE-468. 92pp.

Khattree, R. and D. Naik. 2000. Multivariate data reduction and discrimination with SAS Software, Cary, NC: SAS Institute Inc. 558pp.

Luppold, W. G. 1995. Regional differences in the eastern hardwood sawmilling industry. Forest Prod. J. 45(10):39-43.

Luppold, W.G. 1996. Structural changes in the central applachian hardwood sawmilling industry. Wood and Fiber Sci. 28(3):346-355.

Luppold, W., and M. Bumgardner. 2003. What is low-value and/or low-grade hardwood? Forest Prod. J. 53(3):54-59 
Mayer, R. and J. Wiedenbeck. 2005. Continuous sawmill studies: Protocols, practices, and profits. Gen.Tech. Rept. GTR-NE-334. USDA Forest Serv., Northeastern Res. Sta., Newtown Square, Pennsylvania. 32pp.

National Hardwood Lumber Assoc. (NHLA). 2003. NHLA Inspection Training Manual. Guide to general instructions \& standard grades for measurement and inspection of hardwood lumber. NHLA, Memphis Tennessee. 107 pp.

Peña, J. M., J. A. Lozano and P. Larrañaga 1999. An empirical comparison of four initialization methods for the K-Means algorithm. Pattern Recognition Letters 20: 1027-1040.

Petutschnigg, A.J. and H. Katz. 2005. A loglinear model approach for evaluating and adopting log and lumber grading strategies. Forest Prod. J. 55: 67-71.

Petutschnigg, A. J., U. Pferschy, H. Katz, G. Kain and A. Teischinger 2009. Algorithms to define limits for wood property categorization. Forest Prod. J. 59: 75-83.

Piva, R. J., and G. W. Cook. 2011. West Virginia timber industry: an assessment of timber product output and use, 2007. Resour. Bull. NRS-46. Newtown Square, PA: U.S. Department of Agriculture, Forest Service, Northern Research Station. 58 p.

Rappold, P. M., D. E. Kline, B. H. Bond and J. K. Wiedenbeck 2009. Reciprocal estimation of the raw material cost of producing hardwood lumber using the principles of activity-based costing. Forest Prod. J. 59(7/8): 84-90.

Richards, D.B. 1973. Hardwood lumber yield by various simulated sawing methods. Forest Prod. J. $23(10): 50-58$.

SAS Institute Inc. 2008. JMPß 8 Statistics and Graphics Guide. Cary, NC: SAS Institute Inc. 1218pp. 
Steele, P. , R. Shi, and M.E. Wengert. 1989. Estimation of best opening face position for asymmetric sawing patterns in hardwood logs. Forest Prod. J. 39(6):15-20.

Shtatland, E.S., K. Kleinman, and E.M. Cain. 2004. A new strategy of model building in PROC LOGISTIC with automatic variable selection, validation, shrinkage and model averaging. SUGI '29 Proceeding, Paper 191-29, Cary, NC: SAS Institute, Inc.

Rappold, P.M., B.H. Bond, J.K. Wiedenbeck, and R. Ese-Etame. 2007. Impact of elliptical shaped red oak logs on lumber grade and volume recovery. Forest. Prod. J. 57(6):70-73.

Vaughan, C.L., A.C. Wollin, K.A. McDonald, and E.H. Bulgrin. 1966. Hardwood log grades for standard lumber. U.S. Forest Service Research Paper FPL 63. 54pp. 